\title{
Integrated study of Mediterranean deep canyons: Novel results and future challenges
}

\author{
M. Canals \\ GRC Geociències Marines, Departament d'Estratigrafia, Paleontologia i Geociències Marines, Facultat de \\ Geologia, Universitat de Barcelona, Martí i Franquès, s/n, 08028 Barcelona, Spain \\ J.B. Company \\ Institut de Ciències del Mar (CSIC), Passeig Marítim de la Barceloneta, 37-49, 08003 Barcelona, Spain \\ D. Martin \\ Centre d'Estudis Avançats de Blanes (CSIC), accés a la Cala Sant Francesc, 14, 17300 Blanes, Girona, \\ Spain

\section{A. Sànchez-Vidal} \\ GRC Geociències Marines, Departament d'Estratigrafia, Paleontologia i Geociències Marines, Facultat de \\ Geologia, Universitat de Barcelona, Martí i Franquès, s/n, 08028 Barcelona, Spain \\ E. Ramírez-Llodrà \\ Institut de Ciències del Mar (CSIC), Passeig Marítim de la Barceloneta, 37-49, 08003 Barcelona, Spain
}

\begin{abstract}
This volume compiles a number of scientific papers resulting from a sustained multidisciplinary research effort of the deep-sea ecosystem in the Mediterranean Sea that started 20 years ago, which has peaked over the last few years thanks to a number of Spanish and European projects like PROMETEO, DOS MARES, REDECO, GRACCIE, HERMES, HERMIONE and PERSEUS, amongst other projects. The geographic focus of most papers is on the NW Mediterranean Sea including the Western Gulf of Lion and the North Catalan margin, with a special attention to submarine canyons, in particular Blanes and Cap de Creus canyons.
\end{abstract}

This introductory article to the Progress in Oceanography special issue on "Mediterranean deep canyons" provides background information needed to better understand the individual papers forming the volume, comments previous reference papers related to the main topics here addressed, and finally highlights the existing relationships between atmospheric forcing, oceanographic processes, seafloor physiography, ecosystem response, and litter and chemical pollution. This article also aims at constituting a sort of glue, in terms of existing knowledge and concepts and novel findings, linking together the other twenty papers in the volume, also including some illustrative figures.

The main driving ideas behind this special issue, particularly fitting to the study area of the NW Mediterranean Sea, could be summarized as follows: (i) the atmosphere and the deep-sea ecosystem are connected through oceanographic processes originating in the coastal area and the ocean surface, which get activated at the occasion of highenergy events leading to fast transfers to the deep; (ii) shelf indented submarine canyons play a 
pivotal role in such transfers, which involve dense water, sedimentary particles, organic matter, litter and chemical pollutants; (iii) lateral inputs (advection) from the upper continental margin contributes significantly to the formation of intermediate and deep water masses, and the associated fluxes of matter and energy are a main driver of deepsea ecosystems; (iv) deep-sea organisms are highly sensitive to the arrival of external inputs, starting from the lowest food web levels and propagating upwards as time passes, which also relies upon the biology, nutritional needs and life expectancy of each individual species; and (v) innovative knowledge gained through such multidisciplinary research is of the utmost significance for an improved management of deep-sea living resources, such as the highly priced red shrimp Aristeus antennatus, for which a pilot management plan largely based in the findings described here and in related articles has been recently published (BOE, 2013).

The researchers involved in such challenging endeavour have learnt tremendously from the results obtained so far and from each other, but are fully aware that there are still many unsolved questions. That is why this introductory article also includes "Future challenges" both in the title as an individual section at the end, to express that there is still a long way to go.

\section{Introduction}

Submarine canyons are seafloor geomorphic features whose existence is known since long (e.g. Heezen and Hollister, 1971). While belonging to the larger family of sea valleys, submarine canyons are a specific type of sea valley carved into the continental margin where they incise the slope and shelf, often off river mouths. It is now known that submarine canyons occur in most continental margins of the world and that they act as exiting routes for water and sediment escaping from the continental shelf.

Some pioneering works about sea valleys focused on their morphology and origin, from where the first attempts to classify them were made. The morphogenetic classification of Shepard and Dill (1966), later refined in Shepard (1973), is still of use. The formation of submarine canyons was early related both to subaerial erosion during sea level low stands and to submarine erosion, eventually favoured by tectonic and/or lithological discontinuities (Reimnitz and Gutierrez-Estrada, 1970; Felix and Gorsline, 1971; Shepard, 1973; Boillot, 1983; Farre et al., 1983; Canals, 1985).

The physical processes occurring within submarine canyons also attracted quite early the interest of the scientific community, either from the sedimentary or the physical oceanography viewpoints (Shepard, 1973; Shepard et al., 1979).

A major change in the perception of submarine canyons occurred with the advent of GPS positioning and multibeam bathymetry. These techniques started to be widely used in marine research in the late 1980s and early 1990s. Acoustics, and multibeam bathymetry in particular, changed our vision of the seafloor and of submarine canyons (Summerhayes and Thorpe, 1996). Their morphology could be then visualised with an unprecedented resolution, which allowed identifying specific features, such as axial incisions or flank terraces, and establishing the hierarchical relations within canyon systems, so that true seafloor drainage networks could be mapped for the first time. These technological advances, jointly with the development of new in situ platforms such as manned submersibles, ROVs, AUVs, benthic landers, moorings and a variety of 
seafloor observatories, paved the road for the modern multipurpose study of the dynamics of submarine canyons of the last two decades, ranging from sedimentary processes and biogeochemical cycling studies to habitat mapping and ecosystem research.

In this paper we present a synthesis of current knowledge about the functioning of submarine canyons in the Mediterranean Sea from a multidisciplinary perspective, with the focus in the Blanes Canyon (BC) and the broader continental margin of the NW Mediterranean Sea including the Western Gulf of Lion and the North Catalan margin. This paper also serves as introduction to the other 20 contributions forming this volume, which includes novel studies on geomorphology, physical oceanography, sedimentary and biogeochemical fluxes, biodiversity and animal behaviour, and anthropogenic impacts. This volume constitutes an attempt to analyse how abiotic and biotic factors interact in the deep submarine canyons and adjacent open slopes of the NW Mediterranean Sea, where they form an essential habitat that is defined by: (i) particular morpho-sedimentary conditions and highly variable hydro-sedimentary processes associated to short-lived high-energy events such as coastal storms, dense shelf water cascading (DSWC) and offshore convection; (ii) conditions particularly favourable to the species recruitment and to the development of biomass maxima for several fish and other species, making canyons key habitats for the maintenance of their populations; and (iii) a well structured community defined by a clear faunal zonation with a welldefined low energy trophic web, which is in a state of fragile equilibrium and is highly sensitive to the impact of anthropogenic and natural changes that are concentrated and focalised by submarine canyons.

\section{Mediterranean deep canyons}

The Mediterranean Sea occupies an area of almost 2.6 million $\mathrm{km} 2$, with an average water depth of about $1500 \mathrm{~m}$ (Amblas et al., 2004). In a global survey, Harris and Whiteway (2011) identified 518 submarine canyons in the Mediterranean Sea with a depth range in excess of $1000 \mathrm{~m}$, a width/length ratio less than

150:1 and a depth incision in excess of $100 \mathrm{~m}$, as part of a world total of 5849 large canyons. This figure is to be compared with the area $(2,967,000 \mathrm{~km} 2)$ and the volume $(4,390,000 \mathrm{~km} 3)$ of the Mediterranean Sea with respect to the global ocean $(361,900,000 \mathrm{~km} 2$ and 1,335,000,000 km2, respectively) (Eakins and Sharman, 2010). In other words, while only representing the $0.8 \%$ of the area and $0.3 \%$ of the volume of the world's oceans, the Mediterranean contains $8.85 \%$ of the submarine canyons. Canyons in the Mediterranean are also most closely spaced (14.9 km only) and more dendritic (12.9 limbs per 100,000 km2) than in any other geographic region (see Fig. 4 in Harris and Whiteway, 2011). These simple data highlight the relevance of submarine can-yons in the Mediterranean Sea and points to its significance for the functioning of this land-locked basin.

Due to its enclosed character and restricted exchanges with the open ocean, the Mediterranean Sea is strongly influenced by landderived inputs of water, sediment, nutrients, litter and chemical pollutants. Rivers enter the Mediterranean Sea mainly from its northern shore that drains the wetter European watersheds compared to those in North Africa and the Middle East (Ludwig et al., 2003). The main exception is the Nile, 
which does not obey to the atmospheric patterns of the Mediterranean region but to those from Equatorial Africa.

The sediment load by these rivers, jointly with the tectonic background and the geological history of the basin, which includes its drying-up in Messinian times, have largely determined the formation and development of the large number of submarine canyons of various sizes carved in the continental margins of the Mediterranean Sea (see Hsü, 1972, 1977). It has been long believed that canyon formation and reshaping essentially occurred during geological sea level low stands (i.e. during glaciations and glacial transitions), when the subaerial exposure of the shelf and upper margin eased erosion and canyon carving (Posamentier et al., 1988). Recent studies in the Mediterranean Sea and elsewhere challenged this paradigm, as high-energy, atmosphere-driven physical oceanographic processes are also able to erode and shape the deep seafloor, and especially submarine canyons, under high sea level conditions like the present ones (Shepard and Emery, 1973; Kineke et al., 2000; Mulder et al., 2001; Khripounoff et al., 2003, 2009; Paull et al., 2003; Puig et al., 2004, 2008; Canals et al., 2006, 2009; Covault et al., 2007; Lastras et al., 2007; Boyd et al., 2008; SanchezVidal et al., 2012; Stabholz et al., 2013; Xu et al., 2004). The high-energy physical oceanographic processes acting in the NW Mediterranean Sea are described in the next section.

Due to its complex geological history, at the boundary between the major Eurasian and African lithospheric plates, the Mediterranean Sea has been qualified as "a sea of seas", meaning that each sub-basin has a different history and physiography (Fig. 1). Despite this, submarine canyons of different sizes, lengths and incision depths occur in all Mediterranean continental margins from the Gibraltar Strait to the Levantine Basin, as it could be easily verified either through multibeam bathymetry compilations (Medimap Group, 2005, 2008) or simply by a close look to ETOPO1 or Google-Earth. A number of papers dealing with different aspects of Mediterranean submarine canyons, including geomorphic ones, has been recently compiled in Würtz (2012). The NW Mediterranean margins are the most densely canyoned in the entire basin, and form an intricate dendritic system of tributaries, main courses and some distributaries (Fig. 2). Canyons draining the Ebro and Catalan margins (see Amblas et al., 2006) open into the base of slope or directly into the mid-ocean type Valencia Channel at depths of 1500-2000 m, while the Cap de Creus and the Western Gulf of Lion canyons open into the meridian Sete Canyon, which itself ends in the northern Algero-Balearic bathyal plain at about $2600 \mathrm{~m}$ depth. The Rhone deep-sea fan and a number of canyons directly opening into the Algero-Balearic plain dominate the Eastern Gulf of Lion.

Five main submarine canyons, namely Foix, Blanes, La Fonera, Cap de Creus and Lacaze-Duthiers, occur from south to north along the Southern and Northern Catalan margins (sensu Amblas et al., 2006) and the westernmost Gulf of Lion, a $300 \mathrm{~km}$ in length margin segment in the NW Mediterranean Sea. In addition of their individual size (i.e. total length, width and volume), two main geomorphic parameters seem particularly relevant in terms of determining canyon dynamics. These are the incision length (IL) into the continental shelf measured with respect to the shelf edge location and the shortest distance of the canyon tip to the shoreline (DS). This two parameters, IL and DS, largely control the ability of a canyon to capture shelf dense waters (resulting either from evaporation, cooling or sediment loading) and the littoral drift of sediment, especially during high-energy episodes, when the wave base attains larger depths over the shelf thus easing the transport of particles into the canyon. Fig. 3 depicts 
these two parameters, for the above-mentioned five main canyons and also for some smaller canyons in the same area. It is obvious from that figure that these five main canyons, including the $\mathrm{BC}$, hold a strong potential of being directly influenced by physical processes triggered in shallow coastal and shelf waters. Harris and Whiteway (2011) distinguished three canyon types: (i) shelf incising, river associated (i.e. those which heads have a clear bathymetric connection to a major river system), (ii) shelf incising (i.e. those with no clear bathymetric connection to a major river system), and (iii) blind (headless) for those incised into the continental slope, which in a way is a recognition of the significance of shelf incision. These authors allocate only La Fonera Canyon (LFC) to type (i), while actually all the submarine canyons within the study area are river-influenced as they were, though to a larger extent, during Quaternary sea level low-stands. Harris and Whiteway (2011) also ignore other highly relevant physical processes occurring over the shelf that largely determine the dynamics of these canyons (see next section). Geomorphic elements other than incision, such as the configuration of the coastline that could deviate coastal currents towards the canyon head, can also strongly influence the dynamics of submarine canyons (Canals et al., 2006). Shelf incision and distance to the nearest shoreline could be relevant for other aspects too, as benthic ecosystems in shelf incising canyons seem to contain greater diversity and biomass, and more vulnerable marine ecosystems than non-incising canyons, as indicated in some Atlantic canyons but also in the NW Mediterranean Sea (Mortensen and Buhl-Mortensen, 2005; Orejas et al., 2009). This has been attributed to the ability of shelf incising canyons to intercept and trap organic matter-rich sediments and suspensates from the continent and the inner shelf (Harris and Whiteway, 2011, and references therein). The main geomorphic parameters of the submarine canyons along the Southern and Northern Catalan margins and the Western Gulf of Lion are summarized in Table 1. BC to which most contributions to this volume refer to is one of the largest amongst those that have their tip at less than $5 \mathrm{~km}$ from the shoreline (DS $=4$ $\mathrm{km}$ ), with IL equal to $16.2 \mathrm{~km}$, a total length of $184 \mathrm{~km}$, and a depth range from 70 to $2600 \mathrm{~m}$ resulting in a total along axis depth difference of $2530 \mathrm{~m}$. Its width among edges ranges from 6 to $12.1 \mathrm{~km}$ while the width of its floor increases down axis from 0.7 to $1.2 \mathrm{~km}$ at 1000 and $2000 \mathrm{~m}$, respectively. It is also the most sinuous of the canyons included in Table 1, with a sinuosity index of 1.47 , mainly due to the meandering character of its lower course (Fig. 2). A detailed description of the BC head and upper course was presented by Lastras et al. (2011), who also included a useful figure showing the along-axis profiles of the three large canyons cut into the Northern Catalan margin (their Fig. 12). Duran et al. (this volume) present the morphology, sediment dynamics and post-glacial evolution of the continental shelf surrounding the $\mathrm{BC}$ head and upper course. The morphology of Cap de Creus Canyon (CCC) and the interpretation of its sediment dynamics are carefully described in Lastras et al. (2007).

\section{Atmosphere and ocean dynamics}

\subsection{Atmospheric forcing}

Interactions between the atmosphere and the ocean are of particular significance in the Mediterranean Sea, which occupies the $30-45^{\circ} \mathrm{N}$ critical longitudinal belt amidst the arid North African system and the wetter NE Atlantic climate belt. This is well illustrated by the atmospheric pressure gradient expressed by the index known as the North Atlantic Oscillation (NAO), identified since long as the main mode of winter 
climatic variability in the North Atlantic region (e.g. Wanner et al., 2001). The NAO index expresses the pressure difference between the Azores High and the Iceland Low. NAO positive values correspond to a strong latitudinal pressure gradient, a powerful anticyclone and a pronounced low, which triggers strong westerlies leading to cold and dry winter conditions over the Mediterranean and mild and wet winters over Northern Europe. Negative NAO values occur when both the anticyclone and the low are weak and therefore the latitudinal pressure gradient is low, which leads to slower winds ending in wetter mild winters over the Mediterranean and cold winters over Northern Europe.

When the Azores anticyclone is shifted northwards over the NE Atlantic it blocks the westerlies and favours the flow towards the Mediterranean Basin of dry and cold northern air masses generated over a large area extending from the north of Europe, the Arctic and Siberia. The northern cold, dry, strong and often persistent winds reaching the Mediterranean under these atmospheric conditions receive different names from one place to another: tramuntana and mistral in the NW Mediterranean, bora in the Adriatic, and etesian in the Aegean.

However, the NAO explanation was too oversimplified. Recent work has shown that the frequency and intensity of winter windy events over the Mediterranean Basin and the associated heat loss leading to dense water formation are mainly influenced by two large-scale teleconnection patterns or modes of atmospheric variability other than the NAO, which are the East Atlantic Pattern (EAP) and the East Atlantic/Western Russian Pattern (EA/WRP). The EAP is characterized by a dominant high-pressure anomaly to the west of Ireland, as opposed to the NAO, with its north-south dipole with centres over the Azores and Iceland. The EAP is associated to northeasterly flows of cold dry air strongly reinforcing the sea-air temperature and humidity gradients thus easing anomalously larger heat losses over the Mediterranean Sea. The EA/ WRP implies a high-pressure anomaly over Northwest Europe leading to a northerly flux of cold air from Russia and Siberia over the Eastern Basin and triggering a southerly flow of warmer humid air over the Western Basin resulting in heat flux anomalies of opposite sign (Josey et al., 2011).

Though much less investigated than the NAO, the relevance of the EAP is being increasingly recognised. The relationship between large-scale atmospheric patterns and deep-water formation episodes in the entire Mediterranean Basin is indeed more closely related to the EAP than to any other mode of atmospheric variability (Schroeder et al., 2010). The "surprisingly small impact" of the NAO on the overall Mediterranean winter mean heat budget has been stressed by Josey et al. (2011), with magnitudes of the EAP of about $25 \mathrm{Wm}-2$ and strong impacts on both the Eastern and Western basins, and a full basin anomaly for a unit NAO mode index value of less than $5 \mathrm{~W} \mathrm{~m}-2$ (Fig. 4A). The weakness of the NAO link with some climatic variables in the Mediterranean area and, in particular, over Iberia had been noticed previously by other authors too (e.g. Martin-Vide and Lopez-Bustins, 2006).

The EA/WRP pattern generates a dipole that roughly compensates heat losses on the Eastern Basin with gains in the Western Basin. The influence of these two atmospheric patterns over the dense water formation areas of the Mediterranean (Canals et al., 2009) changes from one to the other, with EA playing a dominant role on the NW Mediterranean and the Adriatic Sea, and EA/WRP in the Aegean Sea (Josey et al., 2011). EAP in particular has been identified as the most determinant atmospheric mode 
in driving extreme sea surface heat loss leading to major production of dense water during the latest high intensity events of winters 2004-05 and 2005-06 in the NW Mediterranean Sea and the Adriatic Sea and, more recently, 2011-12 and 2012-13 basin-wide (Durrieu de Madron et al., 2013, and unpublished data). Our focus on winter conditions is due to the fact that summer contributions to heat flux anomalies are relatively minor at basin scale. In summer subtropical high pressures carry warm and dry air masses that move northward and invade most of the Mediterranean area (Barry and Chorley, 1998; Harding et al., 2009).

The Mediterranean Basin is one of the most cyclogenic regions in the northern hemisphere, which leads to extreme episodes that occur at subannual frequency. Cyclogenesis could be associated to the trapping of cold air pockets during winter and also to the summer warming of the sea surface and subsequent moisture loading of air masses combined with orographic effects (Llasat, 2009). Cyclogenesis is highly relevant to explain precipitation patterns and the development of coastal storms. A lowfrequency climate variability pattern named Western Mediterranean Oscillation (WeMO), which represents an evolution of the so called Mediterranean Oscillation (MO) for the Western Basin only, expresses the pressure anomaly in between the Azores anticyclone and the Ligurian low, using San Fernando (south of Spain) and Padova (northern Italy) as reference stations where good-quality long barometric series are available (Martin-Vide and Lopez-Bustins, 2006). This index, initially proposed to explain precipitation patterns along the eastern façade of Iberia, allows detecting the variability relevant to the cyclogenesis over the Western Mediterranean Basin. WeMO negative phases correlate to periods of higher precipitation and river discharge in the Mediterranean watersheds of Spain and France and a higher frequency of eastern storms in winter months (Lopez-Bustins et al., 2008). This matches with long fetch (about 1000 $\mathrm{km}$ ) wind patterns over the sea surface and the development of humid flows from the east that reach the NE-SW oriented Catalan coastline and nearby areas in the NW Mediterranean Sea (Fig. 4B). These situations steer quick fluvial transport of terrestrial inputs to the sea, coastal and inner shelf abrasion and erosion by high waves and winddriven currents loaded with sediment, and subsequent matter and energy transfers to the deep, mostly along submarine canyons (Sanchez Vidal et al., 2012, this volume). In contrast, WeMO positive phases exclude the occurrence of torrential rainfall over Eastern Spain and Southern France (Martin-Vide and Lopez-Bustins, 2006).

The transfer of cold air masses and cyclone development over our study area triggers synchronous oceanographic responses that go beyond heat losses or precipitation shifts and are of the utmost importance for the functioning of the marine ecosystem as a whole (Canals et al., 2006; Schroeder et al., 2010; Sanchez-Vidal et al., 2012; Stabholz et al., 2013). We refer here to the three oceanographic processes known as the "three tenors" of the NW Mediterranean Basin, which are DSWC, eastern storms and offshore convection, though the later is less relevant in terms of matter transfer to the deep (Fig. $5)$.

\subsection{Dense shelf water cascading}

The global significance of DSWC, with more than 60 locations where it occurs known to date, jointly with the diversity of forming processes and its ecosystemic consequences are being increasingly recognised (Shapiro et al., 2003; Ivanov et al., 2004; Shearman and Brink, 2010; Pattiaratchi et al., 2011). 
In the NW Mediterranean Sea, DSWC, and also offshore convection (see further down), respond to the cooling and evaporation of the sea surface by northern winds blowing during winter months when they trigger "dry storms" while pushing coastal waters offshore. As a consequence, surface waters increase their density till passing a threshold from where they start sinking down to the depth where they are again in density equilibrium. In years of pronounced heat loss and density gain these sinking surface waters attain the seafloor provided the density contrast with ambiance waters is strong enough. These are the years of intense cascading and/or offshore convection. The large shelf of the Gulf of Lion, which is $70 \mathrm{~km}$ wide and covers an area of about 11,000 km2, and to a lesser extent the smaller North Catalan shelves of Roses and La Planassa (Duran et al., 2012), behave as shallow cooling platforms, so that densified surface water first sinks to the shelf floor and then it starts moving over the bottom till the shelf edge to finally cascade downslope mostly along submarine canyons where velocities close to $1 \mathrm{~ms}-1$, or even higher, have been measured $30 \mathrm{~m}$ above the seafloor (Canals et al., 2006; Durrieu de Madron et al., 2013). Coastal configuration locally deflects offshore the path of dense shelf waters, as it is the case of Cap de Creus Peninsula that deviates the dense water flow into $\mathrm{CCC}$, which has been identified as the main conduit for cascading dense shelf waters exiting the Gulf of Lion shelf. These dense waters form a turbulent, several tens of meters thick flow loaded with sedimentary particles, including coarse grain sizes that are able to erode the seafloor, push mooring lines several kilometres down the canyon axis, and polish till shining metallic objects along their path (Lastras et al., 2007; Puig et al., 2008). The main conduits in carrying dense shelf waters downslope are by this order the canyons of Cap de Creus, La Fonera, Blanes and Lacaze-Duthiers (Figs. 1-3).

The volumes of sediment laden shelf water exported to the deep through cascading have been estimated taking the 40-day long in-tense cascading episode of early 2005 as a reference. In total $2270 \mathrm{~km} 3$ of shelf water where exported, of which $1800 \mathrm{~km} 3$ originated over the Gulf of Lion shelf, $360 \mathrm{~km} 3$ over the North Catalan shelves of Maresme, La Planassa and Roses, and $110 \mathrm{~km} 3$ by mixing with ambience waters (Ulses et al., 2008a). The volumes funnelled down Cap de Creus, La Fonera, Blanes and Lacaze-Duthiers canyons during the episode have been estimated at 1010, 390, 390 and $170 \mathrm{~km} 3$, respectively, with the remaining amount being exported by shelf edge spill over and escaping southwards over the shelf (Fig. 6A and B). A better idea of the magnitudes involved could be obtained after some simple comparisons. For instance, the amount of exported water represents two times the water volume over the large Gulf of Lion's shelf or 6.5 times the annual discharge of all Mediterranean rivers according to Ludwig et al. (2003).

Cascading currents have also imprinted the continental shelf, with prominent erosional and non-depositional features on the westernmost Gulf of Lion shelf, the Roses shelf and the shelf around CCC head. BC represents the southernmost significant escape route to the deep for dense shelf waters from the north, with both depositional and erosional features around its head (Duran et al., 2012, this volume). Since sea surface buoyancy is a key parameter in DSWC, dry cold winters with low fluvial discharge are particularly favourable for intense cascades, while wetter winters with high fluvial discharge are less prone due to the formation of a low density, fresher layer at the surface. Cascading episodes usually start in late winter and extend till mid spring, thus overlapping with the annual spring phytoplankton bloom. The sinking and cascading of dense shelf waters likely triggers a compensating flow of offshore waters charged with newly produced organic matter that could be subsequently trapped by the cascading flow, thus being 
injected and fertilizing deep-water communities, as opposite to upwelling areas where surface communities are fertilized. The intensity of cascading episodes may noticeably change from year to year, with high intensity cascades occurring once about every 5-10 years. The impact of such cascades on the deep-water fishery of the highly priced deepsea shrimp Aristeus antennatus has been describe by Company et al. (2008) while their ability to carry organic chemicals and litter to the deep has been studied by Salvado et al. $(2012 \mathrm{a}, \mathrm{b})$ and Ramirez-Llodra et al. (this volume).

\subsection{Offshore convection}

Offshore (or open-ocean) convection has been mainly investigated from a purely physical oceanography viewpoint (Marshall and Schott, 1999). Physical oceanographers recognised offshore convection as a major hydrodynamic process responsible for the ventilation of the deep water in the Western Mediterranean Basin and a main source of Deep Mediterranean Water. While being triggered by atmosphere-driven processes and the loss of buoyancy of surface waters, it leads to the vertical mixing of the off-shelf water column also by late winter and early spring, more or less synchronously with DSWC. The depth of mixing changes from year to year, and can eventually reach the basin floor at more than $2000 \mathrm{~m}$. The resulting homogenisation of the water column has been sometimes explained as vertical "chimneys" along which deep water moves up and surface water moves down. The areal extension of the convection area in the NW Mediterranean Sea, often referred as MEDOC area (MEDOC Group, 1970), shifts from one year to another. One main difference with DSWC is that waters involved in offshore convection are essentially "blue waters", in the sense that they are not loaded with sediment like cascading waters but only mostly with fresh organic matter produced during the above mentioned spring phytoplankton bloom. However, recent work in the MEDOC area has shown that offshore convection can cause significant remobilization of bottom sediments in the deep outer margin and basin, including the sustainment of a several hundred meters thick bottom nepheloid layer (Stabholz et al., 2013). It has been subsequently hypothesised that the associated alteration of the seabed may impact biogeochemical fluxes and the overall functioning of the deep-sea ecosystem.

Recent long-term records from the ANTARES neutrino telescope deployed at $2475 \mathrm{~m}$ of water depth in the Eastern Gulf of Lion have shown major bioluminescence events to occur near-bottom during spring months when convection waters sink down to the deep basin (Tamburini et al., 2013). Bioluminescence increases with increased current speed, salinity and temperature, which are indicative of the intrusion of convection waters into the deep basin. Such bioluminescence explosions could be attributed either to the reaction of organisms to enhanced turbulent motion, to an augmentation of collisions of small-sized particles with organisms and of organisms amongst themselves, to the increase of communication and attraction/defence signals, or to the stimulation of feeding and mating activities. In any case, what is most relevant is that those bioluminescence events constitute a compelling evi-dence of the quick response of the deep-sea pelagic ecosystem to seasonal atmospheric forcing leading to dense water formation and sinking, a largely unexplored field (Tamburini et al., 2013).

Other recent studies have focused on the combined effects of concurrent DSWC and offshore convection. Durrieu de Madron et al. (2013) have shown that after the massive formation of dense water on the Gulf of Lion continental shelf and deep basin in winter 2012, the dense water of coastal origin created a distinct bottom layer up to a few 
hundreds of meters thick over the central part of the NW Mediterranean Basin, which was overlain by a layer of newly formed deep water produced by open-sea convection.

Altogether, DSWC and offshore deep convection have to be considered major drivers for the deep pelagic and benthic ecosystems in the Mediterranean Sea and its northwestern region in particular, as they intermittently fuel them with labile organic matter from the coastal ocean and the surface photic layer while disrupting deep water habitats by sediment transport, reworking and resuspension (Canals et al., 2009; Stabholz et al., 2013).

\subsection{Eastern storms}

Eastern storms in the NW Mediterranean Sea are an oceanographic response to cyclogenesis leading to the generation of eastern winds that become charged with moisture while blowing over the sea surface, thus triggering "wet storms" while pushing offshore waters shoreward (Fig. 6C). These storms could be particularly violent and cause serious coastal damage, as known from historical records. They are associated to heavy rains over the coastal watersheds that lead to destructive flash floods carrying large amounts of water and sediment that form suspension plumes off river and torrent mouths with the coarsest fractions moving as bed load. Large swell and breaking waves and intensified currents massively resuspend and remobilise sediment over the continental shelf down to unusually large water depths. By using a significant wave height of $4.3 \mathrm{~m}$ as threshold value, Sanchez-Vidal et al. (2012) identified 16 severe and extreme costal storms that hit the North Catalan coast in the last 25 years, which correspond to storm categories 4 (severe storm) and 5 (extreme storm) of Mendoza and Jimenez (2009). These results in a mean of one severe or extreme coastal storm every one and a half year.

The power of eastern storms was dramatically illustrated by the last major event of the 26th of December 2008, when 14.4 and $8.0 \mathrm{~m}$ high waves were measured by coastal buoys nearby the heads of La Fonera and Blanes submarine canyons (www.puertos.es). This storm was accompanied by $180 \mathrm{~mm}$ of rain in just one day and by a 60 -fold discharge increase of Tordera River, which related to prominent near bottom peaks of suspended sediment concentration (up to $30 \mathrm{~g} \mathrm{~m}-3$ at $1200 \mathrm{~m}$ ) and significant (up to 70 $\mathrm{cm} \mathrm{s}-1$ in the canyon head) current increases $30 \mathrm{~m}$ above the bottom, as measured by a number of mooring arrays at 300, 1200 and $1500 \mathrm{~m}$ of water depth along BC axis, a situation that could be compared to the one recently described in the Gaoping submarine canyon off southern Taiwan as a consequence of a tropical cyclone-(typhoon) induced flood (Liu et al., 2013). The measurements in BC, and also those in the Gaoping Canyon, clearly indicate a link in between sediment loading of a near-bottom water mass and an increase in its speed while moving down along a slope or a canyon axis, a situation that has been also described because of sediment loading of deep water masses after resuspension by bottom trawling (Puig et al., 2012).

In addition of coastal infrastructure destruction, beach erosion and loses of human lives, the December 2008 storm had a tremendous impact on the shallow benthic communities along the North Catalan shelf, as nicely illustrated by a series of in situ photographs in Sanchez-Vidal et al. (2012), their Fig. 3. These pictures showed the reworking and removal of shelf floor sediment, including large size fractions, and the extensive abrasion and sediment burial of benthic communities, whose debris subsequently added 
to the pool of resuspended organic matter susceptible of being exported elsewhere, either along the coast or offshore. Such quickly remobilized shallow-water reservoir of marine organic carbon (OC) was associated to the finest particle size fraction, which eased its redistribution across the deep margin and basin down to at least $1500 \mathrm{~m}$ deep, as observed in the BC, and probably deeper. The in situ measurements by SanchezVidal et al. (2012) convincingly demonstrated how efficient coastal storms could be in carrying OC from shallow to deep water, thus contributing to its sequestration.

\subsection{The Northern Current and its interaction with Blanes Canyon}

The Northern Current (NC) is a permanent mesoscale circulation pattern that flows from the Ligurian Sea to the Gulf of Lion and then southwards over the continental slope off Catalonia (Fig. 6). It constitutes a sort of background motion that is there all the time and to which high-energy events such as the above described shelf cascading, offshore convection and eastern storms superimpose occasionally. The NC has been studied from various viewpoints, of which the most relevant for the present issue likely are the study on how its variability may influence the across-margin fluxes of matter and energy in the Gulf of Lion by Flexas et al. (2002) and the illustration of its relation with the dispersal of sus-pensate plumes by Arnau et al. (2004).

The current speed situation inside BC when any of the "three tenors"' is in action, such as the above-reported eastern storm of December 2008, contrasts with the mean intensity of deep currents solely driven by the NC (i.e. under calm conditions). Grounded on the previous work by Flexas et al. (2008), Jorda et al. (this volume) identify two main current variability modes resulting from (i) intensifications of the contour-parallel pattern of currents over the canyon and (ii) upwelling events along the canyon axis with upwelled water cropping out at the canyon head likely in response to offshore displacements of the NC, an hypoth-esis that is further supported by the findings of Ahumada-Sempoal et al. (this volume). The later group of authors also found that the southwards flowing $\mathrm{NC}$ tends to be faster and deeper in winter, and slower and shallower in summer, and that the fluctuating threedimensional circulation patterns inside the canyon off cascading and stormy periods are associated to the recurrent passage of meanders and eddies by this permanent current, especially in winter time.

The above descriptions depict an overall cycle in BC and nearby area with a clearly defined seasonal bi-pole, with a raging winter season when DSWC, offshore convection and occasional eastern storms occur, and a calm summer season when the NC becomes the dominant influence, only interrupted by sporadic eastern storms.

\section{Particle fluxes to the seafloor}

Particle fluxes to the deep continental margin and basin of the NW Mediterranean Sea are directly determined by margin's physiography, atmospheric conditions, background and event-driven oceanographic processes (i.e. the NC and the "three tenors") and inputs of allochtonous and autochtonous materials, altogether forming the set of abiotic factors controlling the ecosystem. Rivers play a major role in sediment and organic matter transport from terrestrial environment to the ocean. The regime of Mediterranean 
rivers is highly irregular, and so are their contributions. However, riverine inputs of organic matter could represent a relevant food source to marine ecosystems, including the deep-sea ones. Sanchez-Vidal et al. (this volume) have found that rivers opening to the North Catalan margin modulate not only the quantity but also the quality (composition, depending on source) of organic matter inputs to the sea as a function of their regime shifts. The strong seasonal pattern also marks the timing of the main inputs of $\mathrm{OC}$ and $\mathrm{N}$ to the sea, which are mostly transported during floods. Their exportation to the deep margin and basin depends on high-energy oceanographic processes, such as large coastal storms and DSWC.

Sediment traps moored in deep canyons and neighbouring open slopes of the NW Mediterranean Sea have revealed the spatial and temporal variability of particle fluxes to the deep seafloor and shifts in their biogeochemical composition. In general, high particle fluxes occur by lateral advection in late winter and early spring due to DSWC and in autumn and winter because of eastern storms (see above), which contrasts with low particle fluxes in summer months when vertical hemipelagic settling prevails under quiescent atmospheric and oceanographic conditions.

\subsection{Shelf resuspension and downcanyon sediment transport}

Strong near bottom currents caused both by waves, mostly during eastern storms, and flows of dense shelf water induce sufficient turbulence and shear stress on the shelf floor, and eventually on the slope floor, to erode them and resuspend and entrain lithogenic and biogenic particles, thus promoting off-shelf in-masse exportation events (LopezJurado et al., 2005; Canals et al., 2006; Ulses et al., 2008b; Sanchez-Vidal et al., 2012). Whereas storm events induce quick (in 1 day) and large $(1 \mathrm{~cm})$ changes of the shelf seabed level, the intense and persistent (around two months) dense shelf water flows can lead to a slower but continuous and larger erosion $(2 \mathrm{~cm})$ (Bourrin et al., 2008). The eroded and resuspend shelf sediments are mostly funnelled into the shelf incised canyons (Fig. 3). Near bottom currents associated to eastern storms and DSWC also drive a dominant southwards alongshore transport in the Western Gulf of Lion and North Catalan inner shelves (Guillen et al., 2006; Bourrin et al., 2008; Duran et al., 2012, this volume).

Grain size analyses of the particles caught by near-bottom sediment traps (i.e. usually $30 \mathrm{~m}$ above the seafloor) show that DSWC and eastern storms are able to transport downcanyon coarse sediments in suspension, and presumably as bed load, with up to $70 \%$ sand at the canyon head (Puig et al., 2008; Sanchez-Vidal et al., 2008, 2012). In the CCC, such transport has the potential to abrade the canyon floor and generate largescale erosional furrows (Canals et al., 2006; Puig et al., 2008). Downcanyon flows usually display a decreasing transport capacity, which translates into grain size sorting. Current speed attenuation with increasing distance from shore and depth causes the selective deposition of particles along the canyon floor and axis according to their size, with coarser gravel and sand-sized particles being deposited in the canyon head and upper reaches and finer particles travelling to the mid and lower canyon and beyond (Pedrosa-Pamies et al., this volume; Sanchez-Vidal et al., 2008). Transport of fine particles during and after these events is not near-bottom restricted but distributed in a height range of 200-500 m, or even more, above the seafloor (Canals et al., 2006; Martin et al., 2013), which results in the formation of a long-lasting benthic nepheloid layer covering the entire Western Mediterranean deep basin (Puig et al., 2013). 
When such energetic events occur, near bottom particle fluxes increase by one order of magnitude. At mid canyon depths (i.e. around 1000-1200 m depth) maximum fluxes of 27.0, 90.1, 94.0 and 101.1 g m-2d-1 have been recorded in Lacaze-Duthiers, Cap de Creus, La Fonera and Blanes submarine canyons, respectively (Heussner et al., 2006; Pasqual et al., 2010; Martin et al., 2006; Lopez-Fernandez et al., this volume-b)(Fig. 7). However those total mass fluxes likely are underestimations, as overfilling of the sediment trap cups and sediment trap saturation has been often observed. The downcanyon transport of shelf and upper canyon sedimentary particles frequently follows an in-echelon pattern (Palanques et al., 2012; Lopez-Fernandez et al., this volume-b; Martin et al., 2013). The first energetic event in autumn or winter leads to the remobilization of the loose, erodible top sediment layer on the shelf with subsequent transfer into the canyon head and upper-mid reaches, where it accumulates temporarily. While erodible sediment on the shelf becomes progressively exhausted, DSWC or storm pulses resuspend and transport further downcanyon these temporary deposits (Palanques et al., 2012).

While deep offshore convection is supposed to carry particles from the upper ocean layer, the capacity of the associated currents to induce active sediment resuspension in the deep Western Mediterranean Sea has been documented by Martin et al. (2010), Palanques et al. (2012), Stabholz et al. (2013) and Lopez-Fernandez et al. (this volumeb). The arrival of newly formed deep water through open-ocean convection can thus lead to increased particle fluxes in lower canyon courses and, more generally, in the outer continental margin, and also generate erosional features such as sediment waves, crescent scours and furrows (Stabholz et al., 2013).

\subsection{Biogeochemical composition of the exported particles}

DSWC and storms resuspend, homogenize and transport offshelf large amounts of material, mostly along submarine canyons. When such hydrodynamic events take place the bulk composition of settling particles in the submarine canyons of the NW Mediterranean Sea consists of organic matter and opal contents near 3\% and 1\%, respectively, carbonate contents around $30 \%$ and lithogenic contents (which include quartz, feldspars, heavy minerals and aluminosilicates) close to 66\% (Heussner et al., 2006; Martin et al., 2006; Pasqual et al., 2010; Lopez-Fernandez et al., this volumeb). These values are similar to those measured in shelf and upper slope surface sediments (Roussiez et al., 2006; Pedrosa-Pamies et al., this volume). In contrast, the organic matter and opal contributions peak during the lowest fluxes (up to $24 \%$ and $16 \%$, respectively), which is an indication of less dilution of the background hemipelagic sedimentation signal by lateral advection of resuspended sediments linked to DSWC and storms. In other words, those high-energy, atmosphere driven oceanographic processes directly determine the nature of the sediment record in the inner and mid continental margin, and especially in submarine canyons due to their behaviour as preferential conduits. Accordingly, the contribution of lithogenic dominated, resuspended particle populations is highest in the upper and middle canyon reaches than in the lower canyon course and the open slope (Heussner et al., 2006; Martin et al., 2006; Pasqual et al., 2010; Lopez-Fernandez et al., this volume-b). The biogenic contribution (organic matter, opal and calcium carbonate) to particle fluxes increases downcanyon indicating the decrease of the lateral inputs from resuspension with respect to the primary background flux from superficial waters. 
Despite atmospheric forcing has a profound influence over the amount and composition of particles settling in the studied submarine canyons, seasonality of primary production ultimately controls the export of biogenic particles from surface waters. Primary production in the NW Mediterranean Sea is bi-modal, with two phytoplankton blooms in late winter-early spring and autumn that are typical of mid-latitudes (Longhurst, 1995). The spring bloom is more pronounced due to winter convection, which uplifts deep, nutrient rich waters to the photic zone subsequently triggering a pronounced phytoplanktonic bloom (Fig. 8). The seasonal signal becomes evident from the higher abundance (despite a significant variability) of settling organic matter and opal in spring and autumn (Heussner et al., 2006; Martin et al., 2006; Pasqual et al., 2010; LopezFernandez et al., this volume-b), which results from the export of biogenic remains dominated by calcareous coccolith and foraminifer tests, and siliceous diatom and silicoflagellate skeletons (Rigual-Hernandez et al., 2010, 2012).

\subsection{Implications for the carbon cycle}

DSWC and storms are of strong relevance for the carbon cycle too as OC adsorbed on shelf sedimentary particles is swept and preferentially flushed via submarine canyons to the deep margin and basin thanks to these processes.

Though the advection of land derived organic matter remains active throughout the year regardless of cascading or storms (Tesi et al., 2010b), as shown by the presence of macromolecules exclusively produced by vascular plants, such as lignin and cutin, in sediment traps deployed in the CCC their flux increases from one to two orders of magnitude during DSWC despite the strong dilution of the OC within the total mass flux, which indicates a significant export of terrigenous OC by dense water plumes (Tesi et al., 2010b; Pasqual et al., 2011, this volume). Furthermore, the erosion of consolidated sediments in the mid and outer shelf and in canyon heads during DSWC events is a source of aged OC that is also transferred downcanyon (Tesi et al., 2010a).

When DSWC coincides with the spring phytoplankton bloom, which is often the case, near-bottom dense water plumes flowing off the shelf also entrain newly produced marine OC. This eases the arrival to the deep canyon reaches and, more generally, to the deep margin and basin of large amounts of highly nutritive, fresh organic material, as shown by the composition of chloropigments (Pasqual et al., this volume), protein, carbohydrate and lipid contents (Lopez-Fernandez et al., this volume-a), and OC isotopes (Sanchez-Vidal et al., 2009). This represents an intermittent but plentiful food source for the deep margin and basin ecosystems, i.e. the manna of the abyss.

Hydrodynamic sorting associated to DSWC and storms exerts a strong control on the redistribution of particles with different OC load and composition. Whereas coarse particles transported to the canyon head are poorly loaded with OC, fine particles reaching greater depths are noticeably richer in OC (Tesi et al., 2010b; Pedrosa-Pamies et al., this volume; Sanchez-Vidal et al., 2008, 2012), a significant proportion of which derives from algal primary production and has a high nutritional value (Pedrosa-Pamies et al., this volume; Lopez-Fernandez et al., this volume-a).

All the above observations illustrate how atmospheric forcing triggers the massive export of OC from the shallowest reservoirs to the deep sea, and contributes to its longterm sequestration in the deep ocean where it is less likely to return to the atmosphere. 
Canals et al. (2006) quantified the export of particulate OC by the intense DSWC of winter 2004-05 in $0.7 \times 105$ t OC, which corresponds to 1875 t OC being transported down along the CCC per day during the 40 days that the cascading event lasted. In contrast, the export of particulate OC during storms is more than one order of magnitude lower, as it was calculated at $0.5 \times 104 \mathrm{t}$ OC for the eastern storm that hit the North Catalan coast late in December 2008. This corresponds to $2384 \mathrm{t} \mathrm{OC} \mathrm{d-1} \mathrm{being}$ transported down along $\mathrm{BC}$ each day during the 3 days of duration of the storm, a daily value that is higher than during DSWC. These findings highlight that both DSWC and storms must be considered highly relevant players in the global carbon cycle. Deep offshore convection likely plays a relevant role too, but the magnitudes involved still are poorly constrained.

\subsection{Particle fluxes during calm conditions and anthropogenic impact}

The "three tenors" have a significant impact on hydrodynamics and particle fluxes from canyon heads to the deep margin and basin in autumn, winter and early spring. In contrast, waves, currents and particle fluxes in summer, when atmospheric forcing is minor, are in general much weaker (Fig. 7). Pasqual et al. (2010) and Lopez-Fernandez et al. (this volume-b) report sporadic increases in particle fluxes due to atmospheric dust inputs in summer months. Biomarker signature analyses by Pasqual et al. (this volume) also point to pollen and dust associated with atmospheric inputs as major contributors to the overall fluxes of terrestrial materials during late spring and summer under low energy conditions.

However, such calm conditions are strikingly perturbed by daily anomalous TMF associated to short-lived episodes of high turbidity and current speed that have been identified as caused by bottom trawl-induced sediment gravity flows. These anomalies have been observed repeatedly during weekdays in coincidence with the fleet working hours, and are indicative of periodic sediment removal from fishing grounds (Martin et al., 2008; Puig et al., 2012). Such anthropogenic contributions to TMF are best detected under calm conditions, when they are not diluted amidst naturally higher fluxes, like in autumn, winter and early spring months This trawling-induced sediment removal has caused the general morphology of the deep seafloor to become terraced and smoother over time, both in the source areas (e.g. the fishing grounds at depths less than $900 \mathrm{~m}$ ) and in the accumulation areas (e.g. downslope of the fishing grounds and in canyon floors), thus reducing the original morphological complexity as shown by highresolution seafloor relief maps (Puig et al., 2012).

\section{Abiotic controls on biodiversity and biological processes}

At global scale, deep-water environments represent approximately $60 \%$ of the Earth's surface. In the Mediterranean Sea, with $66 \%$ of its total area lying at depths larger than $500 \mathrm{~m}$, these environments are very extensive too. In the Western Mediterranean Basin the area deeper than $500 \mathrm{~m}$ represents about $77 \%$ of its total (Amblas et al., 2004). Both globally and at Mediterranean scale, this huge, mostly unexplored domain represents the largest and also the least understood ecosystem, which contains an enormous reserve of un-described biodiversity (Grassle and Maciolek, 1992; Brandt et al., 2004; RamirezLlodra et al., 2010). The Mediterranean Sea is one of the most studied regions of the 
world ocean but even so a large part of its deep-water biodiversity remains essentially unknown (Danovaro et al., 2010).

A reliable estimation of the deep-sea species pool, as well as their interactions with the surrounding environment, is essential in the present scenario where increasing anthropogenic disturbance to deep-sea systems overlaps natural abiotic (or environmental) drivers that have been in action for the last millennia at least, consequently determining current biodiversity and biological processes. Anthropogenic impacts, either direct, such as bottom trawling or pollutant and litter release, or indirect, such as those linked to climate change, are now a major player in deep-sea environments that we cannot ignore any longer (Glover and Smith, 2003; Halpern et al., 2008; Puig et al., 2012).

A focused research effort mainly during the last two decades has resulted in an improved knowledge of the main abiotic factors at play in the deep canyons and adjacent slopes of the Western Mediterranean Sea, such as the above-described "three tenors", while for the anthropogenic impacts there is the general perception that, in spite of some relevant findings, so far we have just seen the tip of the iceberg (CastroJimenez et al., this volume; Koenig et al., this volume; Ramirez-Llodra et al., this volume; Salvado et al., this volume; see further down and the papers themselves). The continuation of such investigations will provide the urgently required tools to identify major issues and threats affecting deepsea ecosystems and to evaluate or predict their potential impacts.

The highly dynamic "three tenors" acting in the NW Mediterranean Sea support deepsea ecosystems with inputs of both allochtonous materials mostly by advection and autochtonous particles from the photic zone. Particle settling during calm conditions results in much lower fluxes, though they could be relatively enriched in organic matter (see above). Particles resuspended from the seafloor represent a special category as most of them were initially allochtonous but then became autochtonous, re-entering into the water column from below and not from above, and subsequently resettling. Particle fluxes loaded with organic matter are crucial to sustain deep-sea benthic and pelagic life, especially in oligotrophic systems like the Mediterranean Sea, and may be responsible for the patchy distribution of the established assemblages. As previously depicted, shelfbasin exchanges are particularly enhanced and channelled by submarine canyons (Gooday and Turley, 1990), as illustrated by a number of recent process studies in the Mediterranean Sea and beyond (Canals et al., 2006; Martin et al., 2006; De Stigter et al., 2007, 2011; Durrieu de Madron et al., 2008; Zuñiga et al., 2009; Lastras et al., 2009). Notwithstanding, current understanding of the faunal distribution patterns and biological processes in these environments remains largely insufficient.

\subsection{Community succession in allochtonous wood: from bacteria to xylophagain bivalves}

Due to their behaviour as efficient conduits, submarine canyons may trap and concentrate large organic falls, which create "islands" of enhanced diversity (Snelgrove and Smith, 2002; Bernardino et al., 2010; De Leo et al., 2010). Wood falls in particular may be important organic sources in the deep seafloor, creating unique ecosystems often involving anaerobic conditions (Duperron et al., 2008; Yücel et al., 2013). The functioning of these micro-ecosystems is poorly described globally and has 
rarely been studied in the deep Mediterranean Sea, where high near-bottom water temperatures, usually around $13{ }^{\circ} \mathrm{C}$, result in intensive bacterial degra-dation of sunken organic matter (Legendre and Le Fevre, 1995). The community succession of these ecosystems starts with wooddegrading microbial communities, which are increasingly attracting the interest of the research community (Palacios et al., 2006; Fagervold et al., 2012; Bienhold et al., 2013).

Fagervold et al. (this volume) investigated the role of depth and immersion time on the establishment of microbial communities under Mediterranean deep-water conditions, precisely described the wood associated bacterial assemblage by using the 16S rRNA gene as a phylogenetic marker, and formulated hypotheses on their possible functions in wood degradation after the mooring of wood blocks from 900 to $1800 \mathrm{~m}$ of water depth inside the $\mathrm{BC}$ and on the nearby open slope to the west.

Soon after the bacteria, specialized fauna including the obligate wood-resident species of Xylophaga Turon 1922 (Mollusca, Bivalvia) colonized the wood blocks. While most xylophagain species sampled worldwide have been collected only once, the overall picture points to a surprisingly high species diversity (Voight, 2007), which are able to quickly (i.e. in weeks to a few months) and densely colonize experimental wood deployments (Romey et al., 1994; Turner, 1973; Romano et al., 2011; Voight and Segonzac, 2012), as observed in the BC area. The Xylophagainae, assisted by their bacterial endosymbionts, play a key role in the degradation of wood falls as they convert the refractory cellulose into forms that are more readily available to other deepsea organisms (Turner, 1973; Waterbury et al., 1983; Distel and Roberts, 1997; Distel et al., 2002). The large quantities of organic-rich faecal matter that they produce (Turner, 2002) contribute to the development of un-ique microbial communities inside the bored galleries, which are filled with partially digested wood, and to attract detritivorous invertebrates (Gaudron et al., 2010). The experimental deployments placed in BC and the adjacent open slope allowed obtaining a novel dataset on the colonization of wood substrates by xylophagain bivalves, including the first growth-rate estimates for these peculiar deep-sea bivalves in the Mediterranean Sea (Romano et al., this volume-b).

\subsection{Ecological dynamics of meio-infauna}

Infaunal organisms are those inhabiting the interstitial spaces between sediment grains in the seafloor and sub-seafloor. Meio-infauna groups are infaunal organisms whose individuals are 40-1000 $\mathrm{lm}$ long, i.e. similar to silt and fine-medium sand in terms of size and to marine snow in terms of density. Meio-infauna has been found to equal macrofauna in terms of biomass (Tietjen, 1992).

A variety of fluctuating physical and biogeochemical factors and processes regulate the highly diverse deep-sea faunal communities and their productivity regimes, including infaunal components (Gage, 1996; Billett et al., 1983; Gray, 2001; Snelgrove and Smith, 2002; Vanreusel et al., 2010). However, the interactions between these regulating processes and fauna still are largely unknown, which is particularly critical in highly dynamic, heterogeneous settings, such as submarine canyons where those interactions are responsible for the observed faunal patterns and a presumed higher biodiversity (Ingels et al., 2011a; McClain and Barry, 2010). These processes extend, for instance, from the influence of seasonal surface production (Gooday, 2002) to recurrent disturbance by near bottom flows (Thistle and Sherman, 1985; Aller, 1989, 1997; 
Thistle et al., 1991; Levin et al., 1994; Gage et al., 1995; Guidi-Guilvard et al., 2009; Zuñiga et al., 2009). Like other deep-sea benthic organisms, meio-infauna is affected and responds to such fluctuations and disturbances.

Abiotic factors in canyon systems determine the spatial distribution and density of benthic communities (Cartes et al., 1994; Sarda et al., 1994), which in turn may result in increases of biological productivity and biodiversity influencing higher trophic levels (Vetter and Dayton, 1998; De Leo et al., 2010). However, patterns of benthic community structure with respect to habitat heterogeneity and instability have been studied in relatively few submarine canyons (Garcia et al., 2007; Guidi-Guilvard et al., 2009; Bianchelli et al., 2010).

The multidisciplinary projects conducted during the last two decades in BC area, including concurrent detailed mapping and observation of the seafloor, collection of hydrological data, and extensive particle, sediment and biological sampling paved the ground to investigate the composition and distribution of meiobenthos (Fig. 9) at different locations in terms of bottom morphology, hydrodynamics and biogeochemical fluxes. This allowed Romano et al. (this volume-a) to check to which extent meiofaunal communities from the hydrodynamically disturbed canyon floor sediments differ from those of the more stable adjacent western open slope, and whether the deep-sea meiofaunal density varies with time and/or depth (Ingels et al., this volume).

Nematodes usually are the most abundant metazoans of deep-sea meio-infauna, with their dominance generally increasing and their standing stocks decreasing with depth, respectively (Mokievsky et al., 2007; Vincx et al., 1994). Nematodes allow examining the trophic status of the deep-sea meiobenthos and investigating community dynamics (Soetaert and Heip, 1995). Despite the increasing number of studies on nematodes in submarine canyons in recent years (Koho et al., 2007; Bianchelli et al., 2008, 2010; Danovaro et al., 2009; Guidi-Guilvard et al., 2009; Ingels et al., 2009, 2011a,b,c), intraannual (i.e. seasonal) variability was not addressed. As described in previous sections, environmental conditions in the studied submarine canyons change markedly along the year, with a period from fall to early spring characterized by high-energy processes lasting from days (e.g. storms) to several weeks (e.g. DSWC) that alternates with a usually calm late spring and summer period. High-energy situations involve significant changes of near-bottom physical variables, such as temperature and currents, and peak mass fluxes, while low-energy situations area associated to stable physical conditions and low mass fluxes. Such an environmental setting, where topographic effects also play a relevant role, brings a unique opportunity to investigate the spatial and temporal variability in nematode assemblages at high resolution.

Research on meiobenthic nematode biomass, feeding types and gender-life stage distributions from 300 to $1600 \mathrm{~m}$ of water depth in $\mathrm{BC}$ point to punctual food injections during high-energy events rather than long-term (background) food availability as the main control on nematode size distributions. An observed increase with depth of nematode biomass in spring, when near-bottom current speeds were higher within the canyon and the influx of particulate phytodetritus much greater, also suggests a temporal effect that reverses the common decrease with augmenting water depth (Ingels et al., this volume). In contrast to the generally accepted decreasing trend in nematode size with increasing depth in deep continental margin environments (Thiel, 1975; Sibuet et al., 1989; Vanreusel et al., 1995; Soltwedel et al., 1996; Vanaverbeke et al., 1997; Soetaert et al., 2002, 2009; Udalov et al., 2005), no significant nematode size 
diminution with depth is observed in $\mathrm{BC}$, which is explained by high background food levels directly related to the regional ocean dynamics and the funnelling effect by the canyon itself. In the open slope a clear decline of average individual nematode biomass for adults (both genders) and juveniles from fall to spring is observed. In the open slope it is hypothesized that the higher food availability in spring compared to autumn may lead the nematode community into a "reproductive" state, which is supported by an observed increase of females during the same period; newly produced nematode generations with mainly younger and smaller individuals would then result in an overall size reduction (Ingels et al., this volume).

\subsection{Spatio-temporal variability of faunal diversity and biomass}

Quantitative data on biomass and density of macro-and megabenthic and benthopelagic fish and invertebrate species along bathymetric transects are available from various deep continental margins and basins (Haedrich et al., 1975, 1980; Gage and Tyler, 1991; Sarda et al., 2004; Company et al., 2004; Wei et al., 2010). Submarine canyons show higher diversity and biomass than open slopes (Rowe, 1971; Cartes et al., 1994; Sarda et al., 1994; Vetter and Dayton, 1999; De Leo et al., 2010), with habitat heterogeneity, event-driven disturbances and enhanced productivity thought to be the main drivers of the high biological indices found in submarine canyons (McClain and Barry, 2010).

However, the topographic complexity of submarine canyons, where rough terrains and rock outcrops are common, poses serious difficulties to benthic sampling with conventional samplers such as Agassiz dredges and otter-trawls. Such complexity is well illustrated by Table 1, which provides numerous parameters on the morphometry of submarine canyons of the NW Mediterranean Sea, including maximum flank drop height (e.g. $1620 \mathrm{~m}$ at LFC) and sinuosity (e.g. 1.47 for BC, meaning a meandering course). For this reason, most studies on megafaunal diversity and biomass variability in submarine canyons use semi-quantitative methods, such as ROV photograph and video surveys (Rowe, 1971; Vetter and Dayton, 1999; De Leo et al., 2010; McClain and Barry, 2010; Fabri et al., in press). In comparison, few studies based on trawl sampling are available in submarine canyons, and those existing refer to depths shallower than $500 \mathrm{~m}$ (Cartes et al., 1994; Sarda et al., 1994).

Tecchio et al. (this volume) present one of the rare studies on diversity and biomass variability of megafaunal species along the axis of a submarine canyon, from 900 to $1500 \mathrm{~m}$ depth (i.e. deeper than the maximum trawling depth by the fishing fleet in the $\mathrm{BC}$ area, which is about $800 \mathrm{~m}$ ) during four different seasons in 2008 and 2009, also considering the adjacent open slope. This approach allowed studying intra-annual variability, which again is rather unusual for deep-sea megafaunal species. Two main biomass fractions were differentiated wherever relevant, which are the resident and the mobile biomass. Observations supported extending the depth range of the mid-slope biomass maximum to $1050-1350 \mathrm{~m}$ while also ascertaining its seasonally fluctuating character in terms of depth range. Diversity was higher inside the BC than in the adjacent open slope and megafaunal assemblages differed significantly too. In contrast, total biomass in the two habitats was about the same. It is hypothesized that the arrival of dense water from DSWC and deep offshore convection to the lower mid slope in late winter and early spring, with the associated reinforcement of near-bottom currents, may have determined temporal depth shifts of the biomass maxima, as fish and crustacean populations 
(i.e. the mobile biomass fraction) might have been forced to migrate upslope, in search of calmer conditions, during episodes of sustained strong near-bottom currents to later come back to the initial grounds when the situation gets again quiet enough (Tecchio et al., this volume). Finally, some species like the echinoid Brissopsis lyrifera have been observed only in the canyon habitat, where they appear in high concentrations, while they are absent in the open slope, a contrasting situation that might have been caused by bottom trawling along the open slope, as Tecchio et al. (this volume) suggest.

\subsection{Seasonal movements of deep-sea fish and invertebrate populations}

Evidence that atmospheric forcing drives oceanographic processes also in the deep-sea is now unquestionable (see above). However, there is still a long way to fully understand how such environmental forcing affects deep-sea populations, and synchronous data allowing establishing correlations amongst the two are actually scarce (Billett et al., 1983; Company et al., 2008). Again, this is due to a large extent to the difficulties, both technical and economic, of conducting a long-term intensive sampling effort at great depths and inside canyons in particular.

In the NW Mediterranean Sea, atmosphere-driven oceanographic processes such as DSWC and deep offshore convection have been shown to influence the population movements of the most highly priced fishery resource that is the deep-sea red shrimp

A. antennatus (Company et al., 2008). Concurrently with the winter and early spring funnelling, mostly along submarine canyons, of large volumes of dense water formed over the shelf, and the sinking by open ocean convection of equally large volumes of dense water formed offshore, the presence of A. antennatus in its regular fishing grounds along the continental slope is tremendously reduced, to the point that up to six months long temporary collapses of the fishery may occur in years when these oceanographic processes achieve high intensities (Fig. 10). The cumulated knowledge has been used to stablish a pilot management plan for this species in LFC area, which has been recently published in the Official Gazette of Spain (BOE, 2013).

Three papers of this Special Issue correlate atmosphere-driven oceanographic processes to seasonal movements of deep-sea fish and invertebrate populations at the community (Tecchio et al., this volume) and species level (Aguzzi et al., this volume-a,b). The first paper illustrates a correlation between the seasonal movements of megafaunal organisms in deep-sea communities and the arrival of a newly formed deep-water mass during winter 2009 (see previous section). Aguzzi et al. (this volume-a) describe the relation of light intensity to population displacements of the galatheid crab Munida tenuimana above and below the twilight zone, between 700 and $1500 \mathrm{~m}$ depth. Aguzzi et al. (this volume-b) correlate the seasonal population movements of the most abundant species of deep-sea fishes and decapod crustaceans with the variability in the properties of local water masses. Removing the effect of juvenile recruitment, seasonal depth shifts are identified in adult populations of most target species from winter, when they are deepest, to spring and summer and, finally, autumn when the shallowest distribution occurs prior to a fast bathymetric retreat. This resulted in the iden-tification of a noticeable connection between these population depth shifts and water temperature and salinity changes, as related to the seasonally fluctuating flow of intermediate and deepwater masses and the oscillating depth of their interphase (Massuti et al., 2008; Aguzzi et al., this volume-b). This observations point to a preference for specific water mass 
conditions by each species, thus stimulating individuals to move up and down following seasonal patterns (i.e. seasonal migrations), in search of the highest possible comfort. Given that deep-water adult fishes are not direct consumers of particles, fluctuations in organic matter fluxes appear to be unrelated to the depth movements of fish species. Such fluxes directly sustain instead their preys (Bailey et al., 2006).

\subsection{Reproductive patterns of fishes in deep continental margins}

The reproductive habits of deep-sea organisms in general, and fishes in particular, and their spatio-temporal variability constitute a serious knowledge gap. Timing of gonadal maturation, location and timing of the recruitment processes, and main spawning periods are only some of the key aspects that need to be understood prior to the implementation of credible sustainable management practices for commercial fisheries. Deep-sea fishing is increasing worldwide (Morato et al., 2006; Watson and Morato, 2013) and at current levels of fishing effort many stocks will collapse in the near future or have collapsed already (Rogers and Gianni, 2010; Norse et al., 2012).

Sampling at depths below $1000 \mathrm{~m}$ with two to three months periodicity is rather unusual, except for areas where commercial fisheries are conducted (Rogers and Gianni, 2010). Fernandez-Arcaya et al. (this volume) take advantage of a series of seasonal trawling surveys between 300 and $1750 \mathrm{~m}$ of water depth in BC and adjacent open slope to present an extensive data set on reproduction and recruitment processes of the most abundant deep-sea fish species of the NW Mediterranean margin, providing new insight on general reproductive patterns that could be of interest for other areas in the Mediterranean Sea and beyond where this information is still not available. A seasonal imprint seems to control reproduction, with activity peaking in autumn and winter months in the middle and lower slope depth range $(800-1750 \mathrm{~m})$, and an increase in spawning duration in the lower slope $(1350-1750 \mathrm{~m})$. Due to the much higher TMF in the upper slope $(300-800 \mathrm{~m})$, it is presumed that the species living there do not face energy constrains when reproducing so that no preferential season was identified for spawning females. The spring phytoplankton bloom seems to have little or no effect at all on spawning below $800 \mathrm{~m}$ depth.

\section{Anthropogenic impacts on deep canyons and slopes}

Deep-sea habitats have remained rather remote from public consciousness and, until recently, to policy makers and managerial bodies too (Ramirez-Llodra et al., 2011). Therefore, the consequences of early anthropogenic activities, including extractive ones, did not raise any major social concern.

In the traditional view, the deep-sea was a provider of three main groups of services: (i) as a convenient out of sight waste disposal site, especially when land options were judged not convenient or adequate; (ii) as a potential source of mineral, energy and living resources beyond any national jurisdiction; and (iii) as a suitable ground for the laying of structures and installations such as pipelines or cables. Triggered by the depletion of terrestrial and coastal resources, the interest for deep-sea goods and services has grown so fast in the last few decades that new scientific knowledge needed for a sound, conscious management and exploitation hardly can keep pace with on- 
going and foreseen commercial activities, now feasible thanks to quick technological development (Thiel, 2003).

\subsection{Fishing}

The deep submarine canyons and adjacent slopes of the NW Mediterranean Sea have been increasingly affected by anthropogenic activities and impacts, namely fishing (Sarda et al., 2009; Company et al., 2012; Puig et al., 2012), litter accumulation (Galgani et al., 1995, 1996, 2000; Ramirez-Llodra et al., this volume) and chemical pollution (Rotllant et al., 2006; Heimbürger et al., 2012; Koenig, 2012; Salvado et al., 2012a, 2012b, this volume; Koenig et al., 2013b, 2013c, this volume; Castro et al., this volume). Fishing in the study area has been practiced during centuries, with a major leap forward in the mid-1960s when the fleet, and specially the trawlers, became fully industrialized and their engine power notably increased (Martin et al., 2008). Bottom trawlers now reach $800 \mathrm{~m}$ depth regularly and greater depths occasionally.

The legal ban for commercial bottom trawling below $1000 \mathrm{~m}$ depth for the entire Mediterranean Sea put in place in 2006 (European Union, 2006) offers an opportunity to investigate ecosystem biodiversity and functioning in relatively pristine conditions below that depth and compare them to exploited areas. The issues of fisheries have not been dealt with directly in this Special Issue, where the focus on anthropogenic issues has been given to pollution, both by marine litter and chemicals on sediments and fauna. A recent paper by Puig et al. (2012) published in Nature deals with some of the least known effects of bottom trawling in deep submarine canyons and open slopes, with one of the canyons in the study area as the reference case.

\subsection{Marine litter}

The remoteness of the deep seafloor has induced globally the disposal of residues and litter from land and vessel sources and prevented direct observation and monitoring of their state and effects over the surrounding environment. This situation has also resulted in a slow development of regulations. The Mediterranean countries adopted in $1980 \mathrm{a}$ protocol for the protection of the Mediterranean Sea against pollution from land-based sources within the framework of the 1976 Barcelona Convention, which was subsequently revised in 1996. In the revised version "marine litter" was defined as "any persistent, manufactured or processed solid material discarded, disposed of or abandoned in the marine and coastal environment' (UNEP, 2009).

Quantitative studies on marine litter have mostly investigated floating debris (e.g. Aliani et al., 2003; Barnes and Milner, 2005; Thiel and Haye, 2006) and coastal areas (e.g. Hess et al., 1999; Katsanevakis and Katsarou, 2004), with some information also available from shelf habitats (e.g. Galgani et al., 1995, 2000; Stefatos et al., 1999). Multidisciplinary research in the last years is providing increasing evidence of marine litter accumulation in bathyal and abyssal habitats and its impacts on the organisms living there (Galil et al., 1995; Galgani et al., 1996, 2000, 2010; Galgani and Andral, 1998; Watters et al., 2010; Miyake et al., 2011; Mordecai et al., 2011; Bergmann and Klages, 2012; Wei et al., 2012). 
The first massive disposal of man-made waste reaching deep waters dates from the end of the 18th century, when the residues of the burnt charcoal (called clinker) used in steam engines were dumped overboard, sinking along shipping lanes during a period of 150 years. Clinker is regularly collected from deep canyons, slopes and basins in the Mediterranean Sea, often colonised by the brachiopod Gryphus vitreus (Ramirez-Llodra et al., this volume). Since the 20th century, the main sources of litter are coastal pollution, river discharges, loss of fishing gear and illegal dumping from ships (UNEP, 2007, reviewed in Ramirez-Llodra et al., 2011). Although the 1972 London Convention legally banned dumping waste from ships, illegal dumping of litter, together with the advection of waste from coastal areas and river discharges, still is a major problem, with an estimate of 6.4 million tonnes of litter entering the oceans each year (UNEP, 2009). Marine litter accumulates mainly close to main coastal urban and industrial concentrations and along shipping lanes. In the deep sea, specific geomorphic features such as canyons or seamounts facilitate the transport and accumulation of litter (Galgani et al., 1995, 1996, 2000; Ramirez-Llodra et al., this volume).

The most common marine litter types are plastics, glass and metal objects (UNEP, 2007)(Fig. 11). In some areas paint chips are also very abundant (Galil et al., 1995). Their resistance to degradation and durability makes plastics the most abundant type of marine litter globally (see review in Derraik, 2002), accounting for $60-80 \%$ of the total (Gregory and Ryan, 1997), which has significant effects on the habitat and its fauna. Plastic ingestion can have lethal effects, while entanglement can lead to physical damage, especially to sessile and fragile organisms such as corals and sponges. Furthermore, the slow degradation of plastics results in large quantities of small plastic particles down to micro-plastics accumulating in the deep-sea environment where they are directly ingested by deposit-feeders with yet unknown effects (Thompson et al., 2009; O’Brine and Thompson, 2010).

Evidence of the accumulation of marine litter from the coast down to abyssal depths has been increasing in recent years and this is now a major issue deserving the attention of policy makers, managers and the society at large. The European Council and Parliament issued the Marine Strategy Framework Directive (MSFD) in June 2008 for the establishment of a framework for community action in the field of marine environmental policy. This directive requires the European Commission to define criteria and methodological standards to allow consistency in the approaches to evaluate the extent to which Good Environmental Status (GES) of marine waters and habitats is being achieved. Eleven qualitative descriptors for determining GES have been defined, including marine litter (Annex 1 of the MSFD). Task group 10 addressed the issues related to marine litter and a report was published in 2010 (Galgani et al., 2010), concluding that all member states should undertake an initial evaluation on the current state of research on marine litter and its impacts, to define knowledge gaps and priority research areas as well as to provide the scientific and technical basis for monitoring. The research and monitoring to be undertaken under a coordinated and standardised effort will result in new data from which to develop recommendations and guidelines to assess GES both at the regional and European scales (Galgani et al., 2010).

At the global scale, the Regional Seas Programme and the Global Programme of Action (GPA) are developing UNEP's Global Marine Litter Initiative. In 2009, UNEP published a review on current knowledge on marine litter (UNEP, 2009). Although most regions focused on litter on coastal areas and beaches, the Mediterranean assessment did include two deep-sea studies (Galgani et al., 1995; UNEP, 2009). 
Research results presented in this Special Issue contribute to the gathering of information addressing the important topic of marine litter in the deep Mediterranean Sea from 900 to $3000 \mathrm{~m}$ depth, thus adding to European and global assessments (Ramirez-Llodra et al., this volume). A high amount of litter accumulating in the BC consisted of light debris (i.e. plastics), which points to a dominant coastal origin and to the action of down canyon currents such as those occurring during DSWC and storm events. On the contrary, litter in the open slope was mostly heavy (metal, glass and fabrics) and ship-originated.

\subsection{Chemical pollution}

The recently improved sophistication and lowering of detection limits in chemical analyses has shown that chemical pollutants have reached the deep-sea, where they have been identified in water, particles, sediment and organisms. It has been also suggested that the deep-sea is a sink for persistent pollutants (Ballschmiter et al., 1997; Froescheis et al., 2000; Dachs et al., 2002; Wania and Daly, 2002; Koenig et al., 2013b). However, the ecotoxicological consequences of chemical contamination in the deep sea are still barely investigated. The highest concern is about persistent organic pollutants (POPs) including pesticides, herbicides and pharmaceuticals, toxic metals (e.g. $\mathrm{Hg}, \mathrm{Cd}, \mathrm{Pb}, \mathrm{Ni}$ and isotopic tracers) and radioelements. POPs are ubiquitous in environmental matrices and deserve particular consideration because of their high persistence, toxicity, and bioaccumulation and long-range transport potential (Scheringer et al., 2009). Amongst metals, mercury is of high concern because of the intensified toxicity of organic forms such as methylmercury and the accumulative nature of such compounds in predatory fish and consequently in the food web up to humans (Looser et al., 2000). Mercury is a major issue in the Mediterranean Sea, where high concentrations have been observed in fish tissues since the 1970s (Cossa and Coquery, 2005).

River discharge and atmospheric transport are the main sources of chemical pollutants in marine systems. The concentration and distribution of these pollutants in sediments is related to their physicochemical properties and to sediment grain size and composition (Cossa and Coquery, 2005; Salvado et al., this volume). Many chemical pollutants bind with particles in the water column, thus facilitating their transport from surface waters to bathyal and abyssal sediments (Ballschmiter et al., 1997). In continental margins, canyons act as natural conduits of sediment and organic matter from the shelf to the deep basin (see above), providing an efficient pathway for the transport and accumulation of particles and associated contaminants. The role of canyons in carrying pollutants to the deep is enormously reinforced when they are the loci of highly dynamic shelf to basin export processes as those occurring in the NW Mediterranean Sea (i.e. DSWC and storms).

Recent work in the study area has identified some of the highest concentrations of polybromodiphenyl ethers (PBDEs) in superficial sediments of the Gulf of Lion and North Catalan margin to occur in the lower reaches and mouths of submarine canyons, which has been interpreted as due to transport by littoral drift and mesoscale circulation over the continental shelf an upper slope and by downcanyon currents (Salvado et al., 2012a). Organochlorine compounds mostly originating from the Rhone River (i.e. the largest river opening to the Western Mediterranean Sea) have been identified in sediment trap and bottom samples across the study area, with much higher fluxes of polychlorobiphenyls (PCBs), dichlorodiphenyltrichloroethane and its metabolites 
(DDTs), chlorobenzenes (CBzs) - pentachlorobenzene and hexachlorobenzene - and hexachlorocyclohexanes (lindane) found in sediment trap samples along the Cap de Creus and Lacaze-Duthiers submarine canyons and in the nearby open slope during the intense DSWC event of winter 2005-06 and early spring 2006 (Figs. 7A and 10) than during periods with lower energy levels and quieter sedimentation (Salvado et al., $2012 \mathrm{~b}$ ). The highest deposition of these compounds occurred within the 1000-1500 m depth range extending along these canyons but also off canyon likely as a result of dense shelf water overflow. However, it should be noted that no samples were collected inside the canyons at depths in excess of $1500 \mathrm{~m}$, so that the depth range for high fluxes could be even larger. In fact, the winter 2005-06 DSWC event in the NW Mediterranean Sea in-volved the highest settling fluxes of these compounds ever described in deep continental margin and basin settings, with peak values of PCBs (960 ng m-2d-1), CBzs (340 ng m-2d-1) and lindane (180 ng m-2d-1) found at $1000 \mathrm{~m}$ depth in the CCC, and DDTs (2900 ng m-2d-1) found also at $1000 \mathrm{~m}$ depth in the open slope to the south, along the inferred path of canyon overflowing dense shelf waters (Salvado et al., 2012b). Actually, and despite much lower concentrations than those found about 20 years ago, PCBs and DDTs in the Gulf of Lion still exceed the NOAA's ERL (effects range low) Sediment Quality Guideline values at almost all sampled sites (Salvado et al., this volume).

Dioxins have been measured in sediments from the BC area, where samples from the deeper sites inside the canyon, down to $1700 \mathrm{~m}$ depth, were clearly enriched, while this enrichment was not observed in the adjacent open slope (Castro-Jimenez et al., this volume). Finally, trace metals and mercury have been found in deep sediments of the Mediterranean Sea too (e.g. Heimbürger et al., 2012).

Several studies have also provided evidence of the accumulation of chemical pollutants in the deep Mediterranean fauna. Due to their geo-and bioaccumulative nature, chemical pollutants tend to accumulate in megafauna and bioaccumulate in top predators (Unger et al., 1997; Cossa and Coquery, 2005). Research on the accumulation of POPs and their physiological effects on deep Mediterranean megafauna shows that the concentrations and impact of POPs were higher in deep-sea organisms caught within the $\mathrm{BC}$ compared to those from the adjacent slope at $900 \mathrm{~m}$ depth, with hepatic biomarker data also indicating higher exposure to pollutants inside the canyon (Koenig et al., this volume).

Dioxins have also been shown to accumulate in deep-sea megafauna of the Mediterranean Sea, in particular in the commercial shrimp A. antennatus (Rotllant et al., 2006). Castro-Jimenez et al. (this volume) investigated three crustacean species and three fish species in the $\mathrm{BC}$ area. In each group one was pelagic, one nektobenthic (i.e. benthic species with swimming capacities) and one benthic. They noticed that dioxin levels were generally higher inside the canyon, with highest concentrations found in nektobenthic animals, either crustaceans or fishes, which is in agreement with the higher trophic level and expected biomagnification factors of nektobenthic species.

Worryingly, the concentrations of mercury in Mediterranean megafauna, including top predators and the highly priced red shrimp A. antennatus, have been shown to exceed, largely in some cases, the maximum level for seafood consumption of $0.5 \mathrm{lg} / \mathrm{g}$ wet weight established by the European Commission (Cossa and Coquery, 2005; Koenig et al., 2013c)(Fig. 12). It has also been certified recently that deeper-dwelling fish shows 
total mercury values higher than predicted according to their trophic level and body mass (Koenig et al., 2013c).

The above described observations point to a "cleaning role" of the coastal areas and the continental shelf by DSWC and, possibly, by storm related gravity flows, which carry large amounts of pollutants to the deep margin and basin, mostly along submarine canyons, where they accumulate before getting finally buried. It is also likely that offshore convection contributes significantly to the transfer of pollutants from the sea surface to the deep, thus completing the oceanic "pollution pump". The above cleaning role of the shallow compartments by these processes is, therefore, counterbalanced by their "dirtying role" of the deep compartments, where they cause potential ecotoxicological effects still to be fully investigated.

\section{Future challenges}

The benefits of multidisciplinary research to better understand deep-sea ecosystems and provide clues for their sustainable use and exploitation is beyond any doubt. In this Special Issue, and also in this introductory article, authors deal with a broad series of topics referred to the Mediterranean Sea, with the focus in its northwestern region and the Blanes submarine canyon. These topics range from physiographic aspects, with the accent on key parameters that are highly relevant to the dynamics of submarine canyons, such us indentation length and distance to shore of canyon tips, to pollution by litter and chemicals that reinforce the view of submarine canyons as critical vectors for the transfer to the deep of the anthropogenic signal. In between, attention is given to atmospheric forcing, to high energy associated oceanographic processes such as the "three tenors", to the biogeochemistry of particle fluxes and their varying composition following seasonal changes, and to biodiversity and biological processes in bacterial, meiofaunal, macrofaunal and megafaunal communities and species, also considering valuable living resources such as the deep-sea red shrimp $A$. antennatus.

While the geographic scope of this Special Issue is local and, to a point, regional, the topics addressed, the questions posed, the answers found, the uncertainties remaining and the new questions opened are of global relevance to a sound understanding of the functioning of deep-sea ecosystems. It is a research example of the well-known motto "Think globally, act locally", though in this case the other way round would be also right: "Act locally, think globally". We are fully conscious that findings made in the

Mediterranean Sea require groundtruthing in other ocean regions to eventually become globally relevant.

The NW Mediterranean Sea in particular is one of the regions in the world ocean were most marine research has been carried out historically and in the last two decades, mostly funded by the Euro-pean Commission and national agencies. This has helped to understand the pivotal role of atmospheric forcing in driving the deepsea ecosystem by quickly transferring the surface signal to the deep, a point that is being increasingly recognised worldwide (e.g. Ivanov et al., 2004; Canals et al., 2006; Pattiaratchi et al., 2011; Liu et al., 2013). Three processes strongly emerge as the main drivers, which are DSWC, severe coastal storms and deep offshore convection (i.e. our "three tenors"). We know now that the Mediterranean Sea is driven by the same processes acting in its northernmost extensions, which are the NW Mediterranean Sea, the Adriatic Sea and the Aegean Sea, where dense waters form to later sink down and spread over the entire 
deep margin and basin (Canals et al., 2009). It could be now claimed that the Mediterranean Sea is a seasonally driven cascading and offshore convection basin. This represents a major progress with respect to the old view of steady pelagic settling as the main food source for its deep-water communities.

The list of future challenges could be rather long, but they could be grouped according to at least two criteria: scale and ultimate purpose or driving force behind. For the first we could consider challenges at (i) Mediterranean scale, and (ii) global scale, the later related to the far-reaching implications of findings made in the Mediterranean Sea. For the second criteria we could identify (i) scientific challenges and (ii) management and operational challenges, though in practice both are often closely intertwined, as illustrated by the A. antennatus case, where oceanographic processes, the species biology and the fishery yield are strongly interrelated (Company et al., 2008). Some strategic and operational aspects also represent major future challenges.

Without pretending to be exhaustive, these are some relevant future challenges fitting within the above categories, and also encompassing the variety of individual scientific disciplines considered in our multidisciplinary research:

1. Morphometric and physiographic parameters indicate that Mediterranean canyons form a distinct cluster compared to the rest of the canyons in the world ocean (Harris and Whiteway, 2011), but are they so unique that the findings about their functioning are also valid for canyons in other oceanographic settings?

2. DSWC, deep offshore convection and storms also occur in other continental margins of the global ocean (Ivanov et al., 2004), but are their ecosystemic effects similar to those found in the NW Mediterranean Sea?

3. Since compared to DSWC and severe coastal storms carrying near-bottom flows of sediment-laden waters to the deep, offshore convection mostly carries "blue waters" (eventually loaded with newly produced organic matter) to the deep, what is the precise role of the later in driving the deep-water ecosystem?

4. Some recent work (e.g. Durrieu de Madron et al., 2013; Stab-holz et al., 2013) has shown the physical response to interactions between high-energy oceanographic processes, but which are the ecosystem consequences and potentially cumulative effects of interactions between these processes when they occur simultaneously (e.g. DSWC and deep offshore convection) or shortly one after each other (e.g. DSWC and eastern storms, or sets of northern and eastern storms)?

5. The existence of links between high-energy oceanographic processes and the deep ecosystem is now established, but what is the exact nature of the action-response effects between the "three tenors" and deep ecosystem biodiversity and biological processes, and which are the response cycles within single species (e.g. quick response-population bloom-reproduction-return to dormant conditions or disappearance-enhanced recruitment-population bloom, as hypothesized for some jellyfish and crustacean species, respectively -Gili et al., 2000; Company et al., 2008) and the time lag responses by different species? How these impacts are transferred within the food web? Do they dilute the higher in the food web? Do they have multiplying effects? 
6. Like in other deep ocean regions, it has been seen that large organic falls in the $\mathrm{BC}$ area induce the development of a succession of peculiar communities and a biodiversity increase (Romano et al., this volume-a,b and references therein), but beyond essentially descriptive aspects issuing from controlled experiments what is the actual contribution and the role of these communities to the functioning of the deep ecosystem under natural conditions, and how they cope with the presumed rare arrival of such falls to the deep? Further, are these biodiversity hot spots a consequence of local environmental conditions inducing a high degree of endemism in a given canyon or just the expression of a still unexplored connectivity between relatively similar deep-sea systems worldwide?

7. Deep-sea fishery catches have been shown to have a direct and immediate response to the occurrence of atmosphere driven oceanographic processes such as DSWC, illustrated by temporary collapses of the A. antennatus fishery in the NW Mediterranean Sea, followed by recovery and peak captures three to five years after (Company et al., 2008), but how can we be sure that the population reaction in the mid to long term is not modulated by other factors or processes too, as some recent data seem to indicate?

8. Being so strong as they are (e.g. Canals et al., 2006; Durrieu de Madron et al., 2013), to which extent currents associated to the "three tenors", and food inputs that come with, determine larval, juvenile and adult dispersal (e.g. A. antennatus and the above fluctuations of its fishery) and to gene flow amongst geographic areas?

9. The link between high-energy processes and the arrival of pollutants and litter to the deep is reasonably well established now in the NW Mediterranean Sea, especially for DSWC (e.g. Salvado et al., 2012b; Koenig et al., this volume; Ramirez-Llodra et al., this volume), but could this be extended to other geographic areas where the same or similar processes occur?

10. Litter is now part of the deep-sea ecosystem, and so will be for the decades and centuries to come (Galgani et al., 1995; Thompson et al., 2009; UNEP, 2009; O'Brine and Thompson, 2010; Ramirez-Llodra et al., this volume), but in addition of aesthetic and chemical effects how is it affecting animal behaviour (e.g. hiding, competition, predator-prey relations and so on) on top of other biological impacts?

11. Research work in recent years has shown that DSWC, deep offshore convection and severe coastal storms funnel large amounts of OC to the deep where it is partly consumed and buried (Sanchez-Vidal et al., 2008, 2012; Tesi et al., 2010b; Pasqual et al., 2011, this volume; Stabholz et al., 2013), with some attempts to quantify such sequestered carbon that have been made too (e.g. Canals et al., 2006), but how the total amount of OC injected to the deep by these processes can be better quantified and what is their global significance at the light of the maninduced, on-going climate change?

12. It has been anticipated that global warming will have profound effects on the frequency, intensity and eventually the location of key oceanographic processes, including those placed under the umbrella of the "three tenors" in the Mediterranean Sea (e.g. Somot et al., 2006), but how this will modify the role 
they have in modulating and sustaining the deep ecosystem, and in carrying there pollutants and litter, and ultimately which will be the response of the ecosystem?

The implications of high chemical pollution levels detected in valued deep-sea crustaceans and also in fish species constitute a point that should be fully addressed in future research, also be-cause of its potential implications for human health (e.g. Koenig et al., 2013c, this volume).

Amongst the strategic and operational challenges there is clearly a need to reinforce the current global network of permanent deep-sea observatories, routinely including sensors (e.g. $\mathrm{pH}$, light, floc cameras) other than the traditional ones (e.g. T, conductivity, currents), as well as iterative plankton and sediment sampling to monitor biodiversity and its shifts, so that long time series could be obtained and the most relevant events captured. In that respect, the deployment of long term sentinel moorings in strategic locations for the early detection and monitoring of highly dynamic oceanographic processes would be particularly worth the effort. Meteorological stations and metoceanic buoys for weather services, coastal and ocean management, navigation aids, beach and port safety, and a wide range of other uses are also necessary as they are critical to establish and understand the links between the atmosphere, the ocean and, ultimately the deep ecosystem so that an informed exploitation of the goods and services it offers could be achieved. Sadly, the XIOM (Xarxa d'Instruments Oceanogràfics i Meteorològics de Catalunya) network of wave buoys (5) and tide gauges (4) of the Catalan government covering the part of the study area south of Cap de Creus, which was in operation since 1984, is no more active due to budgetary cuts, thus interrupting a precious 29 years long time series. Because of the same reason, Puertos del Estado, an agency of the Spanish govern-ment, has also removed its Palamos buoy, close to the LFC head, which had been in operation since 1988. At present, only two buoys are operational in Spanish waters north of Barcelona. The first one (2001-13), belonging to Puertos del Estado, is located off Cap Begur at $1200 \mathrm{~m}$ of water depth. The second one, including both oceanographic and meteorological sensors, and operated by the Observatory of the Catalan Sea of the Centre for Advanced Studies of Blanes (CEAB-CSIC), is located 3 miles offshore in the BC head, between the continental shelf and the upper slope at $192 \mathrm{~m}$ depth (http://www2.ceab.csic.es/oceans/index_en.html). Overall, this implies that critical datasets on atmospheric forcings and sea state used to prepare the papers in this volume, and other published elsewhere, would not have been available under the present circumstances.

There is also a need to implement fast-response schemes so that devoted teams with ad hoc instrumentation could react quickly and go measuring and sampling when something major happens. A greater development of near-bottom in situ observation capabilities on mobile platforms, such as ROVs and AUVs, allowing a better assessment and monitoring of deep-sea communities and species behaviour under different environmental conditions is highly recommended too. 


\section{Acknowledgements}

The authors want to express their gratitude to the Spanish National RTD program, which funded PROMETEO (ref. CTM200766316-C02-01/MAR), DOS MARES (ref. CTM2010-21810-C03), GRACCIE (ref. CSD2007-00067) and REDECO (ref. CTM200804973-E/MAR) projects supporting the research work on which the papers in this volume are based on. The authors are also grateful to EC funded projects HERMES (ref. GOCE-CT-2005-511234-1), HERMIONE (ref. 226354-HERMIONE) and PERSEUS (Grant agreement no: 287600). Generalitat de Catalunya provided background funding to GRC Marine Geosciences and GRE Benthic Ecology through its grants 2009 SGR 1305 and 2009 SGR 655. We are also in debt with the many crews and colleagues who participated in the numerous expeditions and experiments at sea. David Amblas produced Figs. 1-3, 5 and 6, mounted the cover page, and carried out data calculations for Table 1. Aitor Rumin produced Fig. 4 and provided insight on atmospheric circulation patterns. Sara Roman and Claudio Arca kindly provided the pictures of the meiobenthic organisms in Fig. 9. Samuel Koenig created Fig. 12 and provided insight on chemical pollution issues.

\section{References}

Aguzzi, J., Costa, C., Ketmaier, V., Angelini, C., Antonucci, F., Menesatti, P., Company, J.B., 2013a. Light-dependent genetic and phenotypic differences in the squat lobster Munida tenuimana (Crustacea: Decapoda) along deep continental margins. Progress in Oceanography (this volume).

Aguzzi, J., Company, J.B., Bahamon, N., Flexas, M.M., Tecchio, S., Fernandez-Arcaya, U., Garcia, J.A., Mecho, A., Koenig, S., Canals, M., 2013b. Seasonal bathymetric migrations of deep-sea fishes and decapod crustaceans in the NW Mediterranean Sea. Progress in Oceanography (this volume).

Ahumada-Sempoal, M.A., Flexas, M.M., Bernardelloc, R., Bahamon, N., Cruzado, A., 2013. Northern Current variability and its impact on the Blanes Canyon circulation: a numerical study. Progress in Oceanography (this volume).

Aliani, S., Griffa, A., Molcard, A., 2003. Floating debris in the Ligurian Sea, northwestern Mediterranean. Marine Pollution Bulletin 46, 1142-1149.

Aller, J.Y., 1989. Quantifying sediment disturbance by bottom currents and its effect on benthic communities in a deep-sea western boundary zone. Deep Sea Research Part A. Oceanographic Research Papers 36, 901-934.

Aller, J.Y., 1997. Benthic community response to temporal and spatial gradients in physical disturbance within a deep-sea western boundary region. Deep-Sea Research Part I: Oceanographic Research Papers 44, 39-69.

Amblas, D., Canals, M., Lastras, G., Berne, S., Loubrieu, B., 2004. Imaging the seascapes of the Mediterranean. Oceanography 17 (4), 144-155.

Amblas, D., Canals, M., Urgeles, R., Lastras, G., Liquete, C., Hugues-Clarke, J.E., Casamor, J.L., Calafat, A.M., 2006. Morphogenetic mesoscale analysis of the 
northeastern Iberian margin, NW Mediterranean Basin. Marine Geology 234 (1- 4), 320 .

Arnau, P., Liquete, C., Canals, M., 2004. River mouth plume events and their dispersal in the Northwestern Mediterranean Sea. Oceanography 17 (3), 22-31.

Bailey, D.M., Rhul, H.A., Smith Jr., K.L., 2006. Long-term change in benthopelagic fish abundance in the abyssal northeast Pacific Ocean. Ecology 87, 549-555.

Ballschmiter, K., Froescheis, O., Jarman, W.M., Caillet, G.M., 1997. Contamination of the deep-sea. Marine Pollution Bulletin 34, 288-289.

Barnes, D.K.A., Milner, P., 2005. Drifting plastic and its consequences for sessile organism dispersal in the Atlantic Ocean. Marine Biology 146, 815-825.

Barry, R.G., Chorley, R.J., 1998. Atmosphere, Weather and Climate. Routledge, London, United Kingdom, 536 p.

Bergmann, M., Klages, M., 2012. Increase of litter at the Arctic deep-sea observatory HAUSGARTEN. Marine Pollution Bulletin 64, 2734-2741.

Bernardino, A.F., Smith, C.R., Baco, A., Altamira, I., Sumida, P.Y.G., 2010. Macrofaunal succession in sediments around kelp and wood falls in the deep NE Pacific and community overlap with other reducing habitats. Deep-Sea Research Part I: Oceanographic Research Papers 57, 708-723.

Bianchelli, S., Gambi, C., Pusceddu, A., Danovaro, R., 2008. Trophic conditions and meiofaunal assemblages in the Bari Canyon and the adjacent open slope (Adriatic Sea). Chemistry and Ecology 24, 101-109.

Bianchelli, S., Gambi, C., Zeppilli, D., Danovaro, R., 2010. Metazoan meiofauna in deep-sea canyons and adjacent open slopes: a large-scale comparison with focus on the rare taxa. Deep-Sea Research Part I: Oceanographic Research Papers 57, 420-433.

Bienhold, C., Pop Ristova, P., Wenzhöfer, F., Dittmar, T., Boetius, A., 2013. How deepsea wood falls sustain chemosynthetic life. PLoS ONE 8 (1), e53590. http:// dx.doi.org/10.1371/journal.pone.0053590.

Billett, D.S.M., Lampitt, R.S., Rice, A.L., Mantoura, R.F.C., 1983. Seasonal sedimentation of phytoplankton to the deep-sea benthos. Nature 302, 520-522.

BOE (Boletín Oficial del Estado), 2013. Orden AAA/923/2013, de 16 de mayo, por la que se regula la pesca de gamba rosada (Aristeus antennatus) con arte de arrastre de fondo en determinadas zonas marítimas próximas a Palamós. Ministerio de Agricultura, Alimentación y Medio Ambiente. Boletín Oficial del Estado 126(III), 40016-40022 (of May 27, 2013).

Boillot, G., 1983. Géologie des marges continentales. Masson Ed., Paris, France, 139 p.

Bourrin, F., Durrieu de Madron, X., Heussner, S., Estournel, C., 2008. Impact of winter dense water formation on shelf sediment erosion (evidence from the Gulf of Lions, NW Mediterranean). Continental Shelf Research 28, 1984-1999. 
Boyd, R., Ruming, K., Goodwin, I., Schröder-Adams, C., 2008. Highstand transport of coastal sand to the deep ocean: a case study from Fraser Island, southeast Australia. Geology 36, 15-18.

Brandt, A., De Broyer, C., Gooday, A.J., Hilbig, B., Thomson, M.R.A., 2004. Introduction to ANDEEP (ANtarctic benthic DEEP-sea biodiversity: colonization history and recent community patterns) - a tribute to Howard L. Sanders. Deep-Sea Research Part II: Topical Studies in Oceanography 51, 1457-1465.

Canals, M., 1985. Estructura sedimentaria y evolución morfológica del talud y el glacis continentals del Golfo de León: fenómenos de desestabilización de la cobertera sedimentaria plio-cuaternaria. PhD Thesis, University of Barcelona, Spain, 618 p.

Canals, M., Puig, P., Heussner, S., Durrieu de Madron, X., Palanques, A., Fabres, J., 2006. Flushing submarine canyons. Nature 444 (7117), 354-357. http:// dx.doi.org/10.1038/nature05271.

Canals, M., Danovaro, R., Heussner, S., Lykousis, V., Puig, P., Trincardi, F., Calafat, A.M., Durrieu de Madron, X., Palanques, A., Sanchez-Vidal, A., 2009. Cascades in Mediterranean submarine grand canyons. Oceanographyy 22 (1), 26-43.

Cartes, J.E., Company, J.B., Maynou, F., 1994. Deep-water decapod crustacean communities in the Northwestern Mediterranean: influence of submarine canyons and season. Marine Biology 120, 221-229.

Castro-Jimenez, J., Rotllant, G., Abalos, M., Parera, J., Dachs, J., Company, J.B., Calafat, A., Abad, E., 2013. Accumulation of dioxins in deep-sea crustaceans, fish and sediments from a submarine canyon (NW Mediterranean). Progress in Oceanography 6, 6.

Company, J.B., Maiorano, P., Tselepides, A., Politou, C.H.-Y., Plaity, W., Rotllant, G., Sarda, F., 2004. Deep-sea decapod crustaceans in the western and central Mediterranean Sea: preliminary aspects of species distribution, biomass and population structure. Scientia Marina 68 (3), 73-86.

Company, J.B., Puig, P., Sarda, F., Palanques, A., Latasa, M., Scharek, R., 2008. Climate influence on deep sea populations. PLoS ONE 1, e1431.

Company, J.B., Ramirez-Llodra, E., Sarda, F., Aguzzi, J., Puig, P., Canals, M., Calafat, A.M., Palanques, A., Sole, M., Sanchez-Vidal, A., Martin, J., Lastras, G., Tecchio, S., Koenig, S., Fernandez-Arcaya, U., Mecho, A., y Fernandez, P., 2012. Submarine canyons in the Catalan Sea (NW Mediterranean): megafaunal biodiversity patterns and anthropogenic threats. In: Würtz, M. (Ed.), Mediterranean Submarine Canyons, Ecology and Governance. International Union for the Conservation of Nature and Natural Resources (IUCN), Gland/Malaga, Switzerland/Spain, pp. 133-144.

Cossa, D., Coquery, M., 2005. The Mediterranean mercury anomaly, a geochemical or a biologocal issue. In: Salior, A. (Ed.), Handbook of Environmental Chemistry - The Mediterranean Sea, vol. 5. Springer, pp. 177-208.

Covault, J.A., Normark, W.R., Romans, B.W., Graham, S.A., 2007. Highstand fans in the California borderland: the overlooked deep-water depositional systems. Geology 35 (9), 783-786. 
Dachs, J., Lohmann, R., Ockenden, W.A., Mejanelle, L., Eisenreich, S.J., Jones, K.C., 2002. Oceanic biogeochemical controls on global dynamics of persistent organic pollutants. Environmental Science \& Technology 36, 4229-4237.

Danovaro, R., Bianchelli, S., Gambi, C., Mea, M., Zeppilli, D., 2009. a-, b-, c-, d-and ediversity of deep-sea nematodes in canyons and open slopes of Northeast Atlantic and Mediterranean margins. Marine Ecology Progress Series 396, 197- 209.

Danovaro, R., Company, J.B., Corinaldesi, C., D’Onghia, G., Galil, B., Gambi, C., Gooday, A.J., Lampadariou, N., Luna, G.M., Morigi, C., Olu, K., Polymenakou, P., Ramirez-Llodra, E., Sabbatini, A., Sarda, F., Sibuet, M., Tselepides, A., 2010. Deep-sea biodiversity in the Mediterranean Sea: the known, the unknown, and the unknowable. PLoS ONE 5, e11832.

De Leo, F.C., Smith, C.R., Rowden, A.A., Bowden, D.A., Clark, M.R., 2010. Submarine canyons: hotspots of benthic biomass and productivity in the deep sea. Proceedings of the Royal Society B: Biological Sciences 277, 2783-2792.

De Stigter, H.C., Boer, W., de Jesus Mendes, P.A., Jesus, C.C., Thomsen, L., van den Bergh, G.D., van Weering, T.C.E., 2007. Recent sediment transport and deposition in the Nazare Canyon, Portuguese continental margin. Marine Geology 246, 144-164.

De Stigter, H.C., Jesus, C.C., Boer, W., Richter, T.O., Costa, A., van Weering, T.C.E., 2011. Recent sediment transport and deposition in the Lisbon-Setubal and Cascais submarine canyons, Portuguese continental margin. Deep Sea Research Part II: Topical Studies in Oceanography 58, 2321-2344.

Derraik, J.G.B., 2002. The pollution of the marine environment by plastic debris: a review. Marine Pollution Bulletin 44, 842-852.

Distel, D.L., Roberts, S.J., 1997. Bacterial endosymbionts in the gills of the deep-sea wood-boring bivalves Xylophaga atlantica and Xylophaga washingtona. Biological Bulletin (Woods Hole) 192, 253-261.

Distel, D.L., Beaudoin, D.J., Morrill, W., 2002. Coexistence of multiple proteobacterial endosymbionts in the gills of the wood-boring bivalve Lyrodus pedicellatus (Bivalvia: Teredinidae). Applied and Environmental Microbiology 68, 6292-6299.

Duperron, S., Laurent, M.C.Z., Gaill, F., Olivier, G., 2008. Sulphur-oxidizing extracellular bacteria in the gills of Mytilidae associated with wood falls. FEMS Microbiology Ecology 63, 338-349.

Duran, R., Canals, M., Sanz, J.L., Lastras, G., Amblas, D., Micallef, A., 2012. Morphology and sediment dynamics of the northern Catalan continental shelf, northwestern Mediterranean Sea. Geomorphology. http://dx.doi.org/ 10.1016/j.geomorph.2012.10.004.

Duran, R., Canals, M., Lastras, G., Micallef, A., Amblas, D., Pedrosa-Pamies, R., Sanz, J.L., 2013. Sediment dynamics and post-glacial evolution of the continental shelf around the Blanes submarine canyon head (NW Mediterranean). Progress in Oceanography (this volume).

Durrieu de Madron, X., Wiberg, P.L., Puig, P., 2008. Sediment dynamics in the Gulf of Lions: the impact of extreme events. Continental Shelf Research 28, 1867-1876. 
Durrieu de Madron, X., Houpert, L., Puig, P., Sanchez-Vidal, A., Testor, P., Bosse, A., Estournel, C., Somot, S., Bourrin, F., Bouin, M.N., Beauverger, M., Beguery, L., Calafat, A., Canals, M., Cassou, C., Coppola, L., Dausse, D., D’Ortenzio, F., Font, J., Heussner, S., Kunesch, S., Lefevre, D., Le Goff, H., Martin, J., Mortier, L., Palanques, A., Raimbault, P., 2013. Interaction of dense shelf water cascading and open-sea convection in the northwestern Mediterranean during winter 2012. Geophysical Research Letters 40, 1-7. http://dx.doi.org/10.1002/grl.50331.

Eakins, B.W., Sharman, G.F., 2010. Volumes of the World's Oceans from ETOPO1. NOAA National Geophysical Data Center, Boulder, CO, USA. <http:// www.ngdc.noaa.gov/mgg/global/etopo1_ocean_volumes.html>.

European Union, 2006. Council Regulation (EC) No 1967/2006 of 21 December 2006, Concerning Management Measures for the Sustainable Exploitation of Fishery Resources in the Mediterranean Sea. Official Journal of the European Union, L 409/11.

Fabri, M.-C., Pedel, L., Beuck, L., Galgani, F., Hebbeln, D., Freiwald, A., 2013. Megafauna of vulnerable marine ecosystems in French Mediterranean submarine canyons: Spatial distribution and anthropogenic impacts. Deep-Sea Research II (in press). http://dx.doi.org/10.1016/j.dsr2.2013.06.016.

Fagervold, S.K., Galand, P.E., Zbinden, M., Gaill, F., Lebaron, P., Palacios, C., 2012. Sunken woods on the ocean floor provide diverse specialized habitats for microbes. FEMS Microbiology Ecology 82 (3), 616-628. http://dx.doi.org/ 10.1111/j.15746941.2012.01432.x.

Fagervold, S.K., Bessette, S., Romano, C., Martin, D., Plyuscheva, M., LeBris, N., Galanda, P.E., 2013. Microbial communities associat with the degradation of oak wood in the Blanes submarine canyon and its adjacent open slope (NW Mediterranean). Progress in Oceanography (this volume).

Farre, J.A., Mcgregor, B.A., Ryan, W.B.F., Robb, J.M., Stanley, D.J., Moore, G.T., 1983. Breaching the shelfbreak: passage from youthful to mature phase in submarine canyon evolution. In: Stanley, D.J., Moore, G.T. (Eds.), The Shelfbreak: Critical Interface on Continental Margins. SEPM Sp. Publ. 33, Tulsa, Oklahoma, USA, pp. 2539.

Felix, D.W., Gorsline, D.W., 1971. Newport submarine canyon, California: an example of the effects of shifting loci of sand supply upon canyon position. Marine Geology 10, 177-198.

Fernandez-Arcaya, U., Rotllant, G., Ramirez-Llodra, E., Recasens, L., Aguzzi, J., Flexas, M.M., Sanchez-Vidal, A., Lopez-Fernandez, P., Garcia, J.A., Company, J.B., 2013. Reproductive biology and recruitment of the deep-sea fish community from the NW Mediterranean continental margin. Progress in Oceanography (this volume).

Flexas, M., Garcia, M., Durrieu de Madron, X., Canals, M., Arnau, P., 2002. Flow variability in the Gulf of Lions during the MATER HFF experiment (March-May 1997). Journal of Marine Systems 33-34, 197-214.

Flexas, M.M., Boyer, D.L., Espino, M., Puigdefabregas, J., Rubio, A., Company, J.B., 2008. Circulation over a submarine canyon in the NW Mediterranean. Journal of Geophysical Research 113, C12002. http://dx.doi.org/10.1029/2006JC003998. 
Froescheis, O., Looser, R., Caillet, G.M., Jarman, W.M., Ballschmiter, K., 2000. The deep sea as a global sink for semi-volatile persistent oragnic pollutants? Part I: PCBs in suface and deep-sea dwelling fish of the North and South Atlantic and Monterey Bay Canyon (California). Chemosphere 40, 651-666.

Gage, J.D., 1996. Why are there so many species in deep-sea sediments? Journal of Experimental Marine Biology and Ecology 200, 257-286.

Gage, J.D., Tyler, P.A., 1991. Deep-Sea Biology: A Natural History of Organisms at the Deep-Sea Floor. Cambridge University Press, Cambridge, UK, 504 p.

Gage, J.D., Lamont, P.A., Tyler, P.A., 1995. Deep-sea macrobenthic communities at contrasting sites off Portugal, preliminary results: I. Introduction and diversity comparisons. Internationale Revue der gesamten Hydrobiologie 80, 235-250.

Galgani, F., Andral, B., 1998. Methods for evaluating marine debris on the deep seafloor. In: Oceans'98/IEEE/OES Conference, vol. 3, pp. 1512-1519.

Galgani, F., Jaunet, S., Campillot, A., Guenegen, X., His, E., 1995. Distribution and abundance of debris on the continental shelf of the North-Western Mediterranean Sea. Marine Pollution Bulletin 31, 713-717.

Galgani, F., Souplet, A., Cadiou, Y., 1996. Accumulation of debris on the deep sea floor off the French Mediterranean coast. Marine Ecology Progress Series 142, 225-234.

Galgani, F., Leaute, J.P., Moguedet, P., Souplet, A., Verin, Y., Carpentier, A., Goraguer, H., Latrouite, D., Andral, B., Cadiou, Y., Mahe, J.C., Poulard, J.C., Nerisson, P., 2000. Litter on the sea floor along European coasts. Marine Pollution Bulletin 40, 516- 527.

Galgani, F., Fleet, D., Van Franeker, J., Katsanevakis, S., Maes, T., Mouat, J., Oosterbaan, L., Poitou, I., Hanke, G., Thompson, R., Amato, E., Birkun, A., Janssen, C., 2010. Marine Strategy Framework Directive. Task Group 10 Report: Marine Litter Scientific, vol. EUR 24340 EN-2010, Luxemburg, 48 p.

Galil, B.S., Goliki, A., Turkay, M., 1995. Litter at the bottom of the sea: a sea bed survey in the Eastern Mediterranean. Marine Pollution Bulletin 30, 22-24.

Garcia, R., Koho, K.A., De Stigter, H.C., Epping, E., Koning, E., Thomsen, L., 2007. Distribution of meiobenthos in the Nazare canyon and adjacent slope (western Iberian Margin) in relation to sedimentary composition. Marine Ecology Progress Series 340, 207-220.

Gaudron, S.M., Pradillon, F., Pailleret, M., Duperron, S., Le Bris, N., Gaill, F., 2010. Colonization of organic substrates deployed in deep-sea reducing habitats by symbiotic species and associated fauna. Marine Environmental Research 70, 1- 12.

Gili, J.M., Pages, F., Bouillon, J., Palanques, A., Puig, P., Heussner, S., Calafat, A.M., Canals, M., Monaco, A., 2000. A multidisciplinary approach to the understanding of hydromedusan populations inhabiting Mediterranean submarine canyons. Deep-Sea Research Part I: Oceanographic Research Papers 47, 1513-1533.

Glover, A.G., Smith, C.R., 2003. The deep-sea floor ecosystem: current status and prospects of anthropogenic change by the year 2025. Environmental Conservation 30, 219-241. 
Gooday, A.J., 2002. Biological responses to seasonally varying fluxes of organic matter to the ocean floor: a review. Journal of Oceanography 58, 305-332.

Gooday, A.J., Turley, C.M., 1990. Responses by benthic organisms to inputs of organic material to the ocean floor: a review. Philosophical Transactions of the Royal Society of London A: Mathematical and Physical Sciences 331, 119-138.

Grassle, J.F., Maciolek, N.J., 1992. Deep-sea species richness: regional and local diversity estimates from quantitative bottom samples. American Naturalist 139, 313341.

Gray, J.S., 2001. Marine diversity: the paradigms in patterns of species richness examined. Scientia Marina 65, 41-56.

Gregory, M.R., Ryan, P.G., 1997. Pelagic plastics and other seaborne persistent synthetic debris: a review of Southern Hemisphere perspectives. In: Marine Debris Sources, Impacts and Solutions. Springer-Verlag, New York, USA, pp. 49-66.

Guidi-Guilvard, L.D., Thistle, D., Khripounoff, A., Gasparini, S., 2009. Dynamics of benthic copepods and other meiofauna in the benthic boundary layer of the deep NW Mediterranean Sea. Marine Ecology Progress Series 396, 181-195.

Guillen, J., Palanques, A., Puig, P., Durrieu de Madron, X., Nyffeler, F., 2006. Sediment dynamics during wet and dry storm events on the Têt inner shelf (SW Gulf of Lions). Marine Geology 234, 129-142.

Haedrich, R.L., Rowe, G.T., Polloni, P.T., 1975. Zonation and faunal composition of epibenthic population on the continental slope south of New England. Journal of Marine Research 33, 191-212.

Haedrich, R.L., Rowe, G.T., Polloni, P.T., 1980. The megabenthic fauna in the deep sea south of New England, USA. Marine Biology 57, 165-179.

Halpern, B.S., Walbridge, S., Selkoe, K.A., Kappel, C.V., Micheli, F., D’Agrosa, C., Bruno, J.F., Casey, K.S., Ebert, C., Fox, H.E., Fujita, R., Heinemann, D., Lenihan, H.S., Madin, E.M.P., Perry, M.T., Selig, E.R., Mark Spalding, M., Steneck, R., Watson, R., 2008. A global map of human impact on marine ecosystems. Science 319, 948-952.

Harding, A., Palutifof, J., Holt, T., 2009. The climate system. In: Woodward, J. (Ed.), The Physical Geography of the Mediterranean. Oxford University Press, Oxford, pp. 69-88.

Harris, P.T., Whiteway, T., 2011. Global distribution of large submarine canyons: geomorphic differences between active and passive continental margins. Marine Geology 285, 69-86.

Heezen, B.C., Hollister, C.D., 1971. The Face of the Deep. Oxford University Press, New York, USA, 659 p.

Heimbürger, L.E., Thibodeau, B., Cossa, D., Khripounoff, A., Mas, V., Chiffoleau, J.F., Migon, C., 2012. Mercury and other metals of environmental concern in sediments from the Var canyon and the DYFAMED site (Ligurian Sea, northwestern Mediterranean). Chemical Geology 291, 141-151. 
Hess, N.A., Ribic, C.A., Vining, I., 1999. Benthic marine debris, with an emphasis on fishery-related items, surrounding Kodiak Island, Alaska, 1994-1996. Marine Pollution Bulletin 38, 885-890.

Heussner, S., Durrieu de Madron, X., Calafat, A., Canals, M., Carbonne, J., Delsaut, N., Saragoni, G., 2006. Spatial and temporal variability of downward particle fluxes on a continental slope: lessons from an 8-yr experiment in the Gulf of Lions (NW Mediterranean). Marine Geology 234, 63-92.

Hsü, K.J., 1972. When the Mediterranean dried up. Scientific American 227, 26-36.

Hsü, K.J., 1977. The history of the Mediterranean salinity crisis. Nature 267, 399-403. http://dx.doi.org/10.1038/267399a0.

Ingels, J., Kiriakoulakis, K., Wolff, G.A., Vanreusel, A., 2009. Nematode diversity and its relation to quantity and quality of sedimentary organic matter in the Nazare Canyon, Western Iberian Margin. Deep-Sea Research Part I: Oceanographic Research Papers 56, $1521-1539$.

Ingels, J., Billett, D.S.M., Vanreusel, A., 2011a. An insight into the feeding ecology of deep-sea canyon nematodes - results from field observations and the first insitu 13C feeding experiment in the Nazaré Canyon. Journal of Experimental Marine Biology and Ecology 396, 185-193.

Ingels, J., Billett, D.S.M., Kiriakoulakis, K., Wolff, G.A., Vanreusel, A., 2011b. Structural and functional diversity of Nematoda in relation with environmental variables in the Setubal and Cascais canyons, Western Iberian Margin. Deep Sea Research Part II: Topical Studies in Oceanography 58, 2354-2368.

Ingels, J., Tchesunov, A., Vanreusel, A., 2011c. Meiofauna in the Gollum Channels and the Whittard Canyon, Celtic Margin - how local environmental conditions shape nematode structure and function. PLoS ONE 6, e20094.

Ingels, J., Vanreusel, A., Romano, C., Coenjaerts, J., Flexas, M.M., Zuñiga, D., Martin, D., 2013. Spatial and temporal infaunal dynamics of the Blanes submarine canyon-slope system (NW Mediterranean); changes in nematode standing stocks, feeding types and gender-life stage ratios. Progress in Oceanography (this volume).

International Ocean Commission, International Hydrographic Organization, and British Oceanographic Data Centre (IOC/IHO/BODC), 2003. Centenary Edition of the GEBCO Digital Atlas, Published on CD-ROM on Behalf of the Intergovernmental Oceanographic Commission and the International Hydrographic Organization as part of the General Bathymetric Chart of the Oceans. British Oceanographic Data Centre, Liverpool, United Kingdom.

Ivanov, V.V., Shapiro, G.I., Huthnance, J.M., Aleynik, D.L., Golovin, P.N., 2004. Cascades of dense water around the world ocean. Progress in Oceanography 60, 47-98.

Jorda, G., Flexas, M.M., Espino, M., Calafat, A., 2013. Deep flow variability in a deeply incised Mediterranean submarine valley (Blanes canyon). Progress in Oceanography (this volume). 
Josey, S.A., Somot, S., Tsimplis, M., 2011. Impacts of atmospheric modes of variability on Mediterranean Sea surface heat exchange. Journal of Geophysical Research (Oceans) 116 (C2), C02032.

Katsanevakis, S., Katsarou, A., 2004. Influences on the distribution of marine debris on the seafloor of shallow coastal areas in Greece (Eastern Mediterranean). Water, Air, and Soil Pollution 159, 325-337.

Khripounoff, A., Vangriesheim, A., Babonneau, N., Crassous, P., Dennielou, B., Savoye, B., 2003. Direct observation of intense turbidity current activity in the Zaire submarine valley at $4000 \mathrm{~m}$ depth. Marine Geology 194, 151-158.

Khripounoff, A., Vangriesheim, A., Crassous, P., Etoubleau, J., 2009. High frequency of sediment gravity flow events in the Var submarine canyon (Mediterranean Sea). Marine Geology 263, 1-6. http://dx.doi.org/10.1016/j.margeo.2009.03.014.

Kineke, G.C., Woolfe, K.J., Kuehl, S.A., Milliman, J.D., Dellapenna, T.M., Purdon, R.G., 2000. Sediment export from the Sepik River, PNG: evidence for a divergent sediment plume. Continental Shelf Research 20, 2239-2266.

Koenig, S., 2012. Bioaccumulation of Persistemt Organic Pollutats (POPs) and Biomarkers of Pollution in Mediterranean Deep-Sea Organisms. PhD Thesis, University of Barcelona.

Koenig, S., Fernandez, P., Company, J.B., Huerta, D., Sole, M., 2013a. Are deep-sea organisms dwelling within a submarine canyon more at risk from anthropogenic contamination than those from the adjacent open slope? A case study of Blanes canyon (NW Mediterranean). Progress in Oceanography (this volume).

Koenig, S., Huertas, D., Fernandez, P., 2013b. Legacy and emergent persistent organic pollutants (POPs) in NW Mediterranean deep-sea organisms. Science of the Total Environment 443, 358-366.

Koenig, S., Sole, M., Fernandez-Gomez, C., Diez, S., 2013c. New insights into mercury bioaccumulation in deep-sea organisms from the NW Mediterranean and their human health implications. Science of the Total Environment 442, 329-335.

Koho, K.A., Kouwenhoven, J., de Stigter, H.C., van der Zwaan, G.J., 2007. Benthic foraminifera in the Nazare Canyon, Portuguese continental margin: sedimentary environments and disturbance. Marine Micropaleontology 66, 27-51.

Lastras, G., Canals, M., Urgeles, R., Amblas, D., Ivanov, M., Droz, L., Dennielou, B., Fabres, J., Schoolmeester, T., Akhmetzhanov, A., Orange, D., Garcia-Garcia, A., 2007. A walk down the Cap de Creus canyon, northwestern Mediterranean Sea: recent processes inferred from morphology and sediment bedforms. Marine Geology 246 (2-4), 176-192. http://dx.doi.org/10.1016/j.margeo.2007.09.002.

Lastras, G., Arzola, R.G., Masson, D.G., Wynn, R.B., Huvenne, V.A.I., Hühnerbach, V., Canals, M., 2009. Geomorphology and sedimentary features in the Central Portuguese submarine canyons, Western Iberian margin. Geomorphology 103, 310-329.

Lastras, G., Canals, M., Amblas, D., Lavoie, C., Church, I., De Mol, B., Duran, R., Calafat, A.M., Hughes-Clarke, J.E., Smith, C.J., Heussner, S., "Euroleon” cruise shipboard party, 2011. Understanding sediment dynamics of two large submarine 
valleys from seafloor data: blanes and La Fonera canyons, northwestern Mediterranean Sea. Marine Geology 280, 20-39. http://dx.doi.org/10.1016/ j.margeo.2010.11.005.

Legendre, L., Le Fevre, J., 1995. Microbial food webs and the export of biogenic carbon in oceans. Aquatic Microbial Ecology 9, 69-77.

Levin, L.A., Leithold, E.L., Gross, T.F., Huggett, C.L., DiBacco, C., 1994. Contrasting effects of substrate mobility on infaunal assemblages inhabiting two highenergy settings on Fieberling Guyot. Journal of Marine Research 52, 489-522.

Liu, J.T., Wang, Y.-H., Yang, R.J., Hsu, R.T., Kao, S.-J., Lin, H.-L., Kuo, F.S., 2013. Cyclone-induced hyperpycnal turbidity currents in a submarine canyon. Journal of Geophysical Research (in press). http://dx.doi.org/10.1029/2011JC007630.

Llasat, M.C., 2009. Storms and floods. In: Woodward, J. (Ed.), The Physical Geography of the Mediterranean. Oxford University Press, Oxford, United Kingdom, pp. 513-540.

Longhurst, A., 1995. Seasonal cycles of pelagic production and consumption. Progress in Oceanography 36, 77-167. Looser, R., Froescheis, O., Caillet, G.M., Jarman, W.M., Ballschmiter, K., 2000. The deep-sea as a final global sink of semivolatile persistent organic pollutants? Part II: organochlorine pesticides in surface and deep-sea dwelling fish of the North and South Atlantic and the Monterey Bay Canyon (California). Chemosphere 40, 661-670.

Lopez-Bustins, J.-A., Martin-Vide, J., Sanchez-Lorenzo, A., 2008. Iberia winter rainfall trends based upon changes in teleconnection and circulation patterns. Global and Planetary Change 63, 171-176.

Lopez-Fernandez, P., Bianchelli, S., Pusceddu, A., Calafat, A., Danovaro, R., Canals, M., 2013a. Bioavailable compounds in sinking particulate organic matter, Blanes Canyon, NW Mediterranean Sea: effects of a large storm and sea surface biological processes. Progress in Oceanography (this volume).

Lopez-Fernandez, P., Calafat, A., Sanchez-Vidal, A., Canals, M., Flexas, M.M., Cateura, J., Company, J.B., 2013b. Multiple drivers of particle fluxes in the Blanes submarine canyon and adjacent open slope: results of a year round experiment. Progress in Oceanography (this volume).

Lopez-Jurado, J.L., Gonzalez-Pola, C., Velez-Belchi, P., 2005. Observation of an abrupt disruption of the long-term warming trend at the Balearic Sea, western Mediterranean Sea, in summer 2005. Geophysical Research Letters 32, L24606. http://dx.doi.org/10.1029/2005GL024430.

Ludwig, W., Meybeck, M., Abousamra, F., 2003. Riverine Transport of Water, Sediments, and Pollutants to the Mediterranean Sea, UNEP MAP Technical Report Series 141, UNEP/MAP Athens, $111 \mathrm{p}$.

Marshall, J., Schott, F., 1999. Open-ocean convection: observations, theory, and models. Review of Geophysics 37, 1-64.

Martin, J., Palanques, A., Puig, P., 2006. Composition and variability of downward particulate matter fluxes in the Palamós submarine canyon (NW Mediterranean). Journal of Marine Systems 60 (1-2), 75-97. 
Martin, J., Puig, P., Palanques, A., Masque, P., Garcia-Orellana, J., 2008. Effect of commercial trawling on the deep sedimentation in a Mediterranean submarine canyon. Marine Geology 252, 150-155.

Martin, J., Miquel, J.C., Khripounoff, A., 2010. Impact of open sea deep convection on sediment remobilization in the western Mediterranean. Geophysical Research Letters 37, L13604. http://dx.doi.org/10.1029/2010GL043704.

Martin, J., Durrieu de Madron, X., Puig, P., Bourrin, F., Palanques, A., Houpert, L., Higueras, M., Sanchez-Vidal, A., Calafat, A.M., Canals, M., Heussner, S., Delsaut, N., Sotin, C., 2013. Sediment transport along the Cap de Creus Canyon flank during a mild, wet winter. Biogeosciences 10, 3221-3239.

Martin-Vide, J., Lopez-Bustins, J.-A., 2006. The Western Mediterranean oscillation and rainfall in the Iberian Peninsula. International Journal of Climatology 26, 1455-1475.

Massuti, E., Montserrat, S., Oliver, P., Moranta, J., Lopez-Pardo, J.J., Marcos, M., Hidalgo, M., Guijarro, B., Carbonell, A., Pereda, P., 2008. The influence of oceanographic scenarios on the population dynamics of demersal resources in the western Mediterranean: hypothesis for hake and red shrimp off Balearic Islands. Journal of Marine Systems 7, 421-438.

McClain, C.R., Barry, J.P., 2010. Habitat heterogeneity, disturbance, and productivity work in concert to regulate biodiversity in deep submarine canyons. Ecology 91, 964976.

MediMap Group (including Loubrieu, B., Mascle, J., Marani, M., Berne, S., Canals, M., Acosta, J., et al.), 2005. Morpho-bathymetry of the Mediterranean Sea, E: 1=2 000000 . CIESM/Ifremer Sp. Publ., Maps and Atlases, 2 sheets (Western Mediterranean and Eastern Mediterranean), Montecarlo, Monaco and Brest, France.

MediMap Group (including Loubrieu, B., Mascle, J., Marani, M., Berne, S., Canals, M., Acosta, J., et al.), 2008. Morpho-bathymetry of the Mediterranean Sea, E: $1=2000000$. CIESM/Ifremer Sp. Publ., Maps and Atlases, 2 sheets (Western Mediterranean and Eastern Mediterranean), Montecarlo, Monaco and Brest, France.

MEDOC Group, 1970. Observation of formation of deep water in the Mediterranean Sea. Nature 227, 1037-1040.

Mendoza, E.T., Jimenez, J., 2009. Regional vulnerability analysis of Catalan beaches to storms. Proceedings of the Institution of Civil Engineers, Maritime Engineering 162, $127-135$.

Miyake, H., Shibata, H., Furushima, Y., 2011. Deep-sea litter study using deep-sea observation tools. In: Omori, K., Guo, X., Yoshie, N., Fujii, N., Handoh, I.C., Isobe, A., Tanabe, S. (Eds.), Interdisciplinary Studies on Environmental Chemistry - Marine Environmental Modeling and Analysis. Terrapub, pp. 261-269.

Mokievsky, V.O., Udalov, A.A., Azovskii, A.I., 2007. Quantitative distribution of meiobenthos in deep-water zones of the World Ocean. Oceanology 47, 797-813.

Morato, T., Watson, R., Pitcher, T.J., Pauly, D., 2006. Fishing down the deep. Fish and Fisheries 7, 24-34. Mordecai, G., Tyler, P.A., Masson, D.G., Huvenne, V.A.I., 2011. 
Litter in submarine canyons off the west coast of Portugal. Deep Sea Research II 58, 2489-2496.

Mortensen, P.B., Buhl-Mortensen, L., 2005. Deep-water corals and their habitats in The Gully, a submarine canyon off Atlantic Canada. In: Freiwald, A., Roberts, J.M. (Eds.), Cold-Water Corals and Ecosystems. Springer-Verlag, Berlin, Germany, pp. 247-277.

Mulder, T., Weber, O., Anschutz, P., Jorissen, F., Jouanneau, J.M., 2001. A few month old storm generated turbidite deposited in the Capbreton Canyon (Bay of Biscay, SW France). Geo-Marine Letters 21, 149-156.

Norse, E., Brooke, S., Cheung, W., Clark, M.R., Ekeland, I., Froese, R., Gjerde, K.M., Haedrich, R.L., Heppell, S.S., Morato, T., Morgan, L.E., Pauly, D., Sumaila, R., Watson, R., 2012. Sustainability of deep-sea fisheries. Marine Policy 36, 307-

320. O'Brine, T., Thompson, R.C., 2010. Degradation of plastic carrier bags in the marine environment. Marine Pollution Bulletin 60, 2279-2283.

Orejas, C., Gori, A., Lo Iacono, C., Puig, P., Gili, J.M., Dale, M.R.T., 2009. Cold-water corals in the Cap de Creus canyon, northwestern Mediterranean: spatial distribution, density and anthropogenic impact. Marine Ecology Progress Series 397, 37-51. http://dx.doi.org/10.3354/meps08314.

Palacios, C., Zbinden, M., Baco, A.R., Treude, T., Smith, C.R., Gaill, F., Lebaron, P., Boetius, A., 2006. Microbial ecology of deep-sea sunken wood: quantitative measurements of bacterial biomass and cellulolytic activities. Cahiers de Biologie Marine 47, 415-420.

Palanques, A., Puig, P., Durrieu de Madron, X., Sanchez-Vidal, A., Pasqual, C., Martin, J., Calafat, A., Heussner, S., Canals, M., 2012. Sediment transport to the deep canyons and open-slope of the western Gulf of Lions during the 2006 intense cascading and open-sea convection period. Progress in Oceanography 106, 1-15.

Pasqual, C., Sanchez-Vidal, A., Zuñiga, D., Calafat, A., Canals, M., Durrieu de Madron, X., Puig, P., Heussner, S., Palanques, A., Delsaut, N., 2010. Flux and composition of settling particles across the continental margin of the Gulf of Lion: the role of dense shelf water cascading. Biogeosciences 7, 217-231.

Pasqual, C., Lee, C., Goñi, M.A., Tesi, T., Sanchez-Vidal, A., Calafat, A., Canals, M., Heussner, S., 2011. Use of organic biomarkers to trace the transport of marine and terrigenous organic matter through the southwestern canyons of the Gulf of Lion. Marine Chemistry 126 (1-4), 1-12.

Pasqual, C., M. Goñi, M.A., Tesi, T., Sanchez-Vidal, A., Calafat, A., Canals, M., 2013. Composition and provenance of terrigenous organic matter transported along submarine canyons in the Gulf of Lion (NW Mediterranean Sea). Progress in Oceanography (this volume).

Pattiaratchi, C., Hollings, B., Woo, M., Welhena, T., 2011. Dense shelf water formation along the south-west Australian inner shelf. Geophysical Research Letters 38 (10), L10609. http://dx.doi.org/10.1029/2011GL046816. 
Paull, C.K., Ussler III, W., Greene, H.G., Keaten, R., Mitts, P., Barry, J., 2003. Caught in the act: the 20 December 2001 gravity flow event in Monterey Canyon. Geo-Marine Letters 22, 227-232.

Pedrosa-Pamies, R., Sanchez-Vidal, A., Calafat, A., Canals, M., Duran, R., 2013. Impact of storm-induced remobilization on grain size Distribution and organic carbon content in sediments from the Blanes Canyon area, NW Mediterranean Sea. Progress in Oceanography (this volume).

Posamentier, H.W., Jervey, M.T., Vail, P.R., 1988. Eustatic controls on clastic deposition I - conceptual framework. In: Wilgus, C.K., Hastings, B.S., Kendall, C.G.S.C., Posamentier, H., Ross, C.A., Van Wagoner, J.C. (Eds.), Sea-Level Changes: An Integrated Approach. SEPM Sp. Publ. 42, Tulsa, Oklahoma, pp. 110-124.

Puig, P., Ogston, A.S., Mullenbach, B.L., Nittrouer, C.A., Parsons, J.D., Sternberg, R.W., 2004. Storm-induced sediment gravity flows at the head of the Eel submarine canyon, northern California margin. Journal of Geophysical Research 109, C03019. http://dx.doi.org/10.1029/2003JC001918.

Puig, P., Palanques, A., Orange, D.L., Lastras, G., Canals, M., 2008. Dense shelf water cascades and sedimentary furrow formation in the Cap de Creus Canyon, northwestern Mediterranean Sea. Continental Shelf Research 28, 2017-2030. http://dx.doi.org/10.1016/j.csr.2008.05.002.

Puig, P., Canals, M., Company, J.B., Martin, J., Amblas, D., Lastras, G., Palanques, A., Calafat, A.M., 2012. The ploughing of the deep seafloor. Nature 489, 286-290. http://dx.doi.org/10.1038/nature11410.

Puig, P., Durrieu de Madron, X., Salat, J., Schroeder, K., Martin, J., Karageorgis, A.P., Palanques, A., Roullier, F., Lopez-Jurado, J.L., Emelianov, M., Moutin, T., Houpert, L., 2013. Thick bottom nepheloid layers in the western Mediterranean generated by deep dense shelf water cascading. Progress in Oceanography 111, 1-23.

Pusceddu, A., Mea, M., Gambi, C., Bianchelli, S., Canals, M., Sanchez-Vidal, A., Calafat, A.M., Heussner, S., Durrieu De Madron, X., Avril, J., Thomsen, L., Garcia, R., Danovaro, R., 2010. Ecosystem effects of dense water formation on deep Mediterranean Sea ecosystems: an overview. Advances in Oceanography and Limnology 1, 51-62.

Ramirez-Llodra, E., Brandt, A., Danovaro, R., De Mol, B., Escobar, E., German, C.R., Levin, L.A., Martinez Arbizu, P., Menot, L., Buhl-Mortensen, P., Narayanaswamy, B.E., Smith, C.R., Tittensor, D.P., Tyler, P.A., Vanreusel, A., Vecchione, M., 2010. Deep, diverse and definitely different: unique attributes of the world's largest ecosystem. Biogeosciences 7, 2851-2899.

Ramirez-Llodra, E., Tyler, P.A., Baker, M.C., Bergstad, O.A., Clark, M., Escobar, E., Levin, L.A., Menot, L., Rowden, A.A., Smith, C.R., Van Dover, C.L., 2011. Man and the last great wilderness: human impact on the deep sea. PLoS ONE 6 (8), e22588.

Ramirez-Llodra, E., De Mol, B., Company, J.B., Coll, M., Sarda, F., 2013. Effects of natural and anthropogenic processes in the distribution of marine litter in the deep Mediterranean Sea. Progress in Oceanography (this volume). 
Reimnitz, E., Gutierrez-Estrada, M., 1970. Rapid changes in the head of the Rio Balsas submarine canyon system, Mexico. Marine Geology 8, 245-258.

Rigual-Hernandez, A.S., Barcena, M.A., Sierro, F.J., Flores, J.A., Hernandez-Almeida, I., Sanchez-Vidal, A., Palanques, A., Heussner, S., 2010. Seasonal to interannual variability and geographic distribution of the silicoflagellate fluxes in the Western Mediterranean. Marine Micropaleontology 77, 46-57.

Rigual-Hernandez, A.S., Sierro, F.J., Barcena, M.A., Flores, J.A., Heussner, S., 2012. Seasonal and interannual changes of planktonic foraminifer fluxes in the Gulf of Lions (NW Mediterranean) and their implications for paleoceanographic studies: two 12-year sediment trap records. Deep Sea Research I 66, 26-40.

Rogers, A.D., Gianni, M., 2010. The Implementation of UNGA Resolutions 61/105 and 64/72 in the Management of Deep-Sea fisheries on the high Seas. Report Prepared for the Deep-Sea Conservation Coalition. International Programme on the State of the Ocean, London, United Kingdom, 97 p.

Romano, C., Voight, J.R., Martin, D., 2011. Secrets of the canyon. J.M.B.A. Global Marine Environment 14, 4-6.

Romano, C., Coenjaerts, J., Flexas, M.M., Zuñiga, D., Vanreusel, A., Company, J.B., Martin, D., 2013a. Spatio-temporal variability of meiobenthic density in the Blanes submarine canyon (NW Mediterranean). Progress in Oceanography (this volume).

Romano, C., Voight, J.R., Company, J.B., Plyuscheva, M., Martin, D., 2013 b. Submarine canyons as the preferred habitat by wood-boring species of Xylophaga (Mollusca, Bivalvia). Progress in Oceanography (this volume).

Romey, W.L., Bullock, R.C., DeAlteris, J.T., 1994. Rapid growth of a deep-sea woodboring bivalve. Continental Shelf Research 14, 1349-1359.

Rotllant, G., Abad, E., Sarda, F., Abalos, M., Company, J.B., Rivera, J., 2006. Dioxin compounds in the deep-sea rose shrimp Aristeus antennatus (Risso, 1816) throughout the Mediterranean Sea. Deep Sea Research Part I: Oceanographic Research Papers 53, 1895-1906.

Roussiez, V., Ludwig, W., Monaco, A., Probst, J.-L., Bouloubassi, I., Buscail, R., Saragoni, G., 2006. Sources and sinks of sediment-bound contaminants in the Gulf of Lions (NW Mediterranean Sea): a multi-tracer approach. Continental Shelf Research 26 (16), 1843-1857.

Rowe, G.T., 1971. Observations on bottom currents and epibhentic populations in Hatteras submarine canyon. Deep-Sea Research 18, 569-581.

Salvado, J.A., Grimalt, J.O., Lopez, J.F., Durrieu de Madron, X., Heussner, S., Canals, M., 2012a. Transformation of PBDE mixtures during sediment transport and resuspension in marine environments (Gulf of Lion, NW Mediterranean Sea). Environmental Pollution 168, 87-95.

Salvado, J.A., Grimalt, J.O., Lopez, J.F., Palanques, A., Heussner, S., Pasqual, C., Sanchez-Vidal, A., Canals, M., 2012b. The role of dense shelf water cascading in the transfer of organochlorine compounds to open marine waters. Environmental Science \& Technology 46 (5), 2624-2632. http://dx.doi.org/ 10.1021/es2038189. 
Salvado, J.A., Grimalt, J.O., Lopez, J.F., Durrieu de Madron, X., Pasqual, C., Canals, M., 2013. Distribution of organochlorine compounds in superficial sediments from the Gulf of Lion, Northwestern Mediterranean Sea. Progress in Oceanography (this volume).

Sanchez-Vidal, A., Pasqual, C., Kerherve, P., Calafat, A., Heussner, S., Palanques, A., Durrieu de Madron, X., Canals, M., Puig, P., 2008. Impact of dense shelf water cascading on the transfer of organic matter to the deep Western Mediterranean basin. Geophysical Research Letters 35, L05605.

Sanchez-Vidal, A., Pasqual, C., Kerherve, P., Heussner, S., Calafat, A., Palanques, A., Durrieu de Madron, X., Canals, M., Puig, P., 2009. Across-margin export of organic matter traced by stable isotopes during and off cascading events, northwestern Mediterranean Sea. Limnology \& Oceanography 54 (5), 1488- 1500.

Sanchez-Vidal, A., Canals, M., Calafat, A.M., Lastras, G., Pedrosa-Pamies, R., Menendez, M., Medina, R., Company, J.B., Hereu, B., Romero, J., Alcoverro, T., 2012. Impacts on the deep-sea ecosystem by a severe coastal storm. PLoS ONE 7 (1), 1-7, e30395.

Sanchez-Vidal, A., Higueras, M., Marti, E., Liquete, C., Calafat, A., Kerherve, P., Canals, M., 2013. Riverine transport of terrestrial organic matter to the North Catalan margin, NW Mediterranean Sea. Progress in Oceanography (this volume).

Sarda, F., Cartes, J.E., Norbis, W., 1994. Spatio-temporal structure of the deep-water shrimp Aristeus antennatus (Decapoda: Aristeidae) population in the western Mediterranean. Fishery Bulletin 92, 599-607.

Sarda, F., Calafat, A., Flexas, M.M., Tselepides, A., Canals, M., Espino, M., Tursi, A., 2004. An introduction to Mediterranean deep-sea biology. Scientia Marina 68 (Suppl. 3), $7-38$.

Sarda, F., Company, J.B., Bahamon, N., Rotllant, G., Flexas, M.M., Sanchez, J., Zuñiga, D., Coenjaerts, J., Orellana, D., Jorda, G., Puigdefabregas, J., Sanchez-Vidal, A., Calafat, A., Martin, D., Espino, M., 2009. Relationship between environment and occurrence of the deep-water rose shrimp Aristeus antennatus (Risso, 1816) in the Blanes submarine canyon (NW Mediterranean). Progrress in Oceanography 82, $227-$ 238.

Scheringer, M., Jones, K.C., Matthies, M., Simonich, S., van de Meent, D., 2009. Multimedia partitioning, overall persistence, and long-range transport potential in the context of POPs and PBT chemical assessments. Integrated Environmental Assessment and Management 5, 557-576.

Schroeder, K., Josey, S.A., Herrmann, M., Grignon, L., Gasparini, G.P., Bryden, H.L., 2010. Abrupt warming and salting of the Western Mediterranean Deep Water after 2005: atmospheric forcings and lateral advection. Journal of Geophysical Research (Oceans) 115 (C8), C08029.

Shapiro, G.I., Huthnance, J.M., Ivanov, V.V., 2003. Dense water cascading off the continental shelf. Journal of Geophysical Research 108, 3390-3408. 
Shearman, R.K., Brink, K.H., 2010. Evaporative dense water formation and crossshelf exchange over the northwest Australian inner-shelf. Journal of Geophysical Research $115, \mathrm{C} 06027$.

Shepard, F.P., 1973. Submarine Geology. Harper \& Row Publ, New York, USA, 517 p.

Shepard, F.P., Dill, R.F., 1966. Submarine Canyons and Other Sea Valleys. Rand McNally, Chicago, USA, 381 p.

Shepard, F.P., Emery, K.O., 1973. Congo Submarine Canyon and Fan Valley. AAPG Bulletin 57 (9), 1679-1691.

Shepard, F.P., Marshall, N.F., McLoughlin, P.A., Sullivan, G.G. 1979. Currents in submarine canyons and other sea valleys. AAPG Studies in Geology, vol. 8, Tulsa, Oklahoma, USA, $173 \mathrm{p}$.

Sibuet, M., Lambert, C.E., Chesselet, R., Laubier, L., 1989. Density of the major size groups of benthic fauna and trophic input in deep basins of the Atlantic Ocean. Journal of Marine Research 47, 851-867.

Snelgrove, P.V.R., Smith, C.R., 2002. A riot of species in an environmental calm: the paradox of the species-rich deep-sea floor. Oceanography and Marine Biology - An Annual Review 40, 311-342.

Soetaert, K., Heip, C., 1995. Nematode assemblages of deep-sea and shelf break sites in the North Atlantic and Mediterranean Sea. Marine Ecology Progress Series 125, 171183.

Soetaert, K., Muthumbi, A., Heip, C., 2002. Size and shape of ocean margin nematodes: morphological diversity and depth-related patterns. Marine Ecology Progress Series 242, 179-1793.

Soetaert, K., Franco, M., Lampadariou, N., Muthumbi, A., Steyaert, M., Vandepitte, L., vanden Berghe, E., Vanaverbeke, J., 2009. Factors affecting nematode biomass, length and width from the shelf to the deep sea. Marine Ecology Progress Series 392, 123-132.

Soltwedel, T., Pfannkuche, O., Thiel, H., 1996. The size structure of deep-sea meiobenthos in the north-eastern Atlantic: nematode size spectra in relation to environmental variables. Journal of the Marine Biological Association of the United Kingdom 76, 327-344.

Somot, S., Sevault, F., Deque, M., 2006. Transient climate change scenario simulation of the Mediterranean Sea for the twenty-first century using a high-resolution ocean circulation model. Climate Dynamics 27, 851-879. http://dx.doi.org/ 10.1007/s00382006-0167-z.

Stabholz, M., Durrieu de Madron, X., Canals, M., Khripounoff, A., Taupier-Letage, I., Testor, P., Heussner, S., Kerherve, P., Delsaut, N., Houpert, L., Lastras, G., Dennielou, B., 2013. Impact of open-ocean convection on particle fluxes and sediment dynamics in the deep margin of the Gulf of Lions. Biogeosciences 10, 1097-1116. http://dx.doi.org/10.5194/bg-10-1097-2013. 
Stefatos, A., Charalambakis, M., Papatheodorou, G., Ferentinos, G., 1999. Marine debris on the seafloor of the Mediterranean Sea: examples from two enclosed gulfs in Western Greece. Marine Pollution Bulletin 36, 389-393.

Summerhayes, C.P., Thorpe, S.A. (Eds.), 1996. Oceanography: An Illustrated Guide. Manson Publishing, London, United Kingdom, p. 352.

Tamburini, C., Canals, M., Durrieu de Madron, X., 103 more, 2013. Deep-sea bioluminescence blooms after dense water formation at the ocean surface. PLoS ONE 8 (7), 1-10, e67523.

Tecchio, S., Ramirez-Llodra, E., Aguzzi, J., Sanchez-Vidal, A., Flexas, M.M., Sarda, F., Company, J.B., 2013. Seasonal fluctuations of deep megabenthos: finding evidence of standing stock accumulation in a flux-rich continental slope. Progress in Oceanography (this volume).

Tesi, T., Goñi, M.A., Langone, L., Puig, P., Canals, M., Nittrouer, C.A., Durrieu de Madron, X., Calafat, A., Palanques, A., Heussner, S., Davies, M.H., Drexler, T.M., Fabres, J., Miserocchi, S., 2010a. Reexposure and advection of 14C-depleted organic carbon from old deposits at the upper continental slope. Global Biogeochemical Cycles 24, gb4002.

Tesi, T., Puig, P., Palanques, A., Goñi, M.A., 2010b. Lateral advection of organic matter in cascading-dominated submarine canyons. Progress in Oceanography 84 (3-4), 185-203.

Thiel, H., 1975. The size-structure of the deep-sea benthos. Internationale Revue Der Gesamten Hydrobiologie, 60.

Thiel, H., 2003. Anthropogenic impacts on the deep sea. In: Tyler, P.A. (Ed.), Ecosystems of the World, Ecosystems of the Deep Ocean, vol. 28. Elsevier, Amsterdam, The Netherlands, pp. 427-472.

Thiel, M., Haye, P.A., 2006. The ecology of rafting in the marine environment. III. Biogeographical and evolutionary consequences. Oceanography and Marine Biology: An Annual Review 44, 323-429.

Thistle, D., Sherman, K.M., 1985. The nematode fauna of a deep-sea site exposed to strong near-bottom currents. Deep Sea Research Part A 32A, 1077-1088.

Thistle, D., Ertman, S.C., Fauchald, K., 1991. The fauna of the HEBBLE site: patterns in standing stock and sediment-dynamic effects. Marine Geology 99, 413-422.

Thompson, R.C., Swan, S.H., Moore, C.J., vom Saal, F.S., 2009. Our plastic age. Philosophical Transactions of the Royal Society 364 (1526), 1973-1976.

Tietjen, J.H., 1992. Abundance and biomass of metazoan meiobenthos in the deepsea. In: Rowe, G.T., Pariente, T. (Eds.), Deep-Sea Food Chains and the Global Carbon Cycle. Kluwer Dordrecht, pp. 45-62.

Turner, R.D., 1973. Wood-boring bivalves, opportunistic species in the deep sea. Science $180,1377-1379$. 
Turner, R.D., 2002. On the subfamily Xylophagainae (family Pholadidae, Bivalvia, Mollusca). Bulletin of the Museum of Comparative Zoology 157, 223-308.

Udalov, A.A., Azovsky, A.I., Mokievsky, V.O., 2005. Depth-related pattern in nematode size: what does the depth itself really mean? Progress in Oceanography 67, 123.

Ulses, C., Estournel, C., Puig, P., Durrieu de Madron, X., Marsaleix, P., 2008a. Dense shelf water cascading in the northwestern Mediterranean during the cold winter 2005: quantification of the export through the Gulf of Lion and Catalan margin. Geophysical Research Letters 35, L07610.

Ulses, C., Estournel, C., Durrieu de Madron, X., Palanques, A., 2008b. Suspended sediment transport in the Gulf of Lions (NW Mediterranean): impact of extreme storms and floods. Continental Shelf Research 28 (15), 2048-2070.

UNEP, 2007. Deep-Sea Biodiversity and Ecosystems: A Scoping Report on Their Socio-Economy, Management and Governance. UNEP, Cambridge, United Kingdom, $84 \mathrm{p}$.

UNEP, 2009. Marine Litter: A Global Challenge. UNEP, Nairobi, Kenya, 232 p.

Unger, M.A., Harvey, E., Vadas, G.G., Vecchione, M., 1997. Persistent pollutants in nine species of deep-sea cephalopods. Marine Pollution Bulletin 56, 1486-1512.

Vanaverbeke, J., Arbizu, P.M., Dahms, H.U., Schminke, H.K., 1997. The Metazoan meiobenthos along a depth gradient in the Arctic Laptev Sea with special attention to nematode communities. Polar Biology 18, 391-401.

Vanreusel, A., Vincx, M., Bett, B.J., Rice, A.L., 1995. Nematode biomass spectra at two abyssal Sites in the NE Atlantic with a contrasting food-supply. Internationale Revue Der Gesamten Hydrobiologie 80, 287-296.

Vanreusel, A., Fonseca, G., Danovaro, R., da Silva, M.C., Esteves, A.M., Ferrero, T., Gad, G., Galtsova, V., Gambi, C., Genevois, V., Ingels, J., Ingole, B., Lampadariou, N., Merckx, B., Miljutin, D.M., Miljutina, M., Muthumbi, A., Netto, S.A., Portnova, D., Radziejewska, T., Raes, M., Tchesunov, A., Vanaverbeke, J., Van Gaever, S., Venekey, V., Bezerra, T., Flint, H., Copley, J., Pape, E., Zeppeli, D., Martinez, P., Galeron, J., 2010. The importance of deep-sea macrohabitat heterogeneity for global nematode diversity. Marine Ecology 31, 6-20.

Vetter, E.W., Dayton, P.K., 1998. Macrofaunal communities within and adjacent to a detritus-rich submarine canyon system. Deep Sea Research II 45, 25-54.

Vetter, E.W., Dayton, P.K., 1999. Organic enrichment by macrophyte detritus, and abundance patterns of megafaunal populations in submarine canyons. Marine Ecology Progress Series 186, 137-147.

Vincx, M., Bett, B.J., Dinet, A., Ferrero, T., Gooday, A.J., Lambshead, P.J.D., Pfannkuche, O., Soltwedel, T., Vanreusel, A., 1994. Meiobenthos of the deep Northeast Atlantic. Advances in Marine Biology 30, 2-88. 
Voight, J.R., 2007. Experimental deep-sea deployments reveal diverse Northeast Pacific wood-boring bivalves of Xylophagainae (Myoida: Pholadidae). Journal of Molluscan Studies 73, 377-391.

Voight, J.R., Segonzac, M., 2012. At the bottom of the deep blue sea: a new woodboring bivalve (Mollusca, Pholadidae, Xylophaga) from the Cape Verde Abyssal Plain (subtropical Atlantic). Zoosystema, vol. 34. Publications Scientifiques du Muséum National d'Histoire Naturelle, Paris, pp. 171-180.

Wania, F., Daly, G.L., 2002. Estimating the contribution of degradation in air and deposition to the deep sea to the global loss of PCBs. Atmospheric Environment 36, 5581-5593.

Wanner, H., Brönnimann, S., Casty, C., Gyalistras, D., Luterbacher, J., Schmutz, C., Stephenson, D.B., Xoplaki, E., 2001. North Atlantic Oscillation - concepts and studies. Surveys in Geophysics 22, 321-382.

Waterbury, J.B., Calloway, C.B., Turner, R.D., 1983. A cellulolytic nitrogen-fixing bacterium cultured from the gland of Deshayes in shipworms (Bivalvia: Teredinidae). Science 221, 1401-1403.

Watson, R.A., Morato, T., 2013. Fishing down the deep: accounting for withinspecies changes in depth of fishing. Fisheries Research 140, 63-65.

Watters, D.L., Yoklavich, M.M., Love, M.S., Schroeder, D.M., 2010. Assessing marine debris in deep seafloor habitats off California. Marine Pollution Bulletin 60, 131-138.

Wei, C.-L., Rowe, G.T., Hubbard, G.F., Scheltema, A.H., Wilson, G.D.F., Petrescu, I., Foster, J.M., Wicksten, M.K., Chen, M., Davenport, R., Soliman, Y., Wang, Y., 2010. Bathymetric zonation of deep-sea macrofauna in relation to export of surface phytoplankton production. Marine Ecology Progress Series 399, 1-14.

Wei, C.-L., Rowe, G.T., Nunnally, C.C., Wicksten, M.K., 2012. Anthropogenic “'litter” and macrophyte detritus in the deep Northern Gulf of Mexico. Marine Pollution Bulletin 64, 966-973.

Würtz, M. (Ed.), 2012. Mediterranean Submarine Canyons: Ecology and Governance. IUCN, Gland, Switzerland and Malaga, Spain, 216 p.

Xu, P.J., Noble, M.A., Rosenfeld, L.K., 2004. In-situ measurements of velocity structure within turbidity currents. Geophysical Research Letters 31, L09311. http://dx.doi.org/10.1029/2004GL019718.

Yücel, M., Galand, P.E., Fagervold, S.K., Contreira-Pereira, L., Bris, N.L., 2013. Sulfide production and consumption in degrading wood in the marine environment. Chemosphere 90, 403-409.

Zuñiga, D., Flexas, M.M., Sanchez-Vidal, A., Coenjaerts, J., Calafat, A., Jorda, G., Garcia-Orellana, J., Puigdefabregas, J., Canals, M., Espino, M., Sarda, F., Company, J.B., 2009. Particle fluxes dynamics in Blanes submarine canyon (Northwestern Mediterranean). Progress in Oceanography 82, 239-251.

http://oceancolour.jrc.ec.europa.eu/: Webpage of the Ocean Colour Portal of the Institute for Environment and Sustainability (Joint Research Centre of the European 
Commission, Ispra, Italy, from where SeaWiFS Monthly Chlorophyll-a Concentration Maps have been Obtained.

www.puertos.es/oceanografia_y_meteorologia/redes_de_medida/index.html: Puertos del Estado (the Spanish Port Authority) Web Page where Metoceanic Data could be Checked and Downloaded. 
Fig. 1. General bathymetry and topography of the Mediterranean region highlighting margin segments where the main concentrations of shelf-incised submarine canyons occur (yellow rectangles). The main rivers are also shown (in blue). 1: Southeast Spain. 2: NW Mediterranean Sea. 3: Ligurian Sea. 4: West Corsica. 5. West Sardinia. 6. East Sardinia. 7: Campania margin. 8: West Calabria margin. 9: Taranto Gulf. 10: West Peloponnese margin. 11. Fethiye margin. 12: Antalya-Northwest Cyprus margin. 13: West Egypt-East Libya margin. 14: East Algeria margin. One minute (latitude by longitude) grid resolution altimetry produced from the GEBCO Digital Atlas published by the British Oceanographic Data Centre on behalf of the International Ocean Commission and British Oceanographic Data Centre (2003). For interpretation of the references to colour in this figure legend, the reader is referred to the web version of this article.

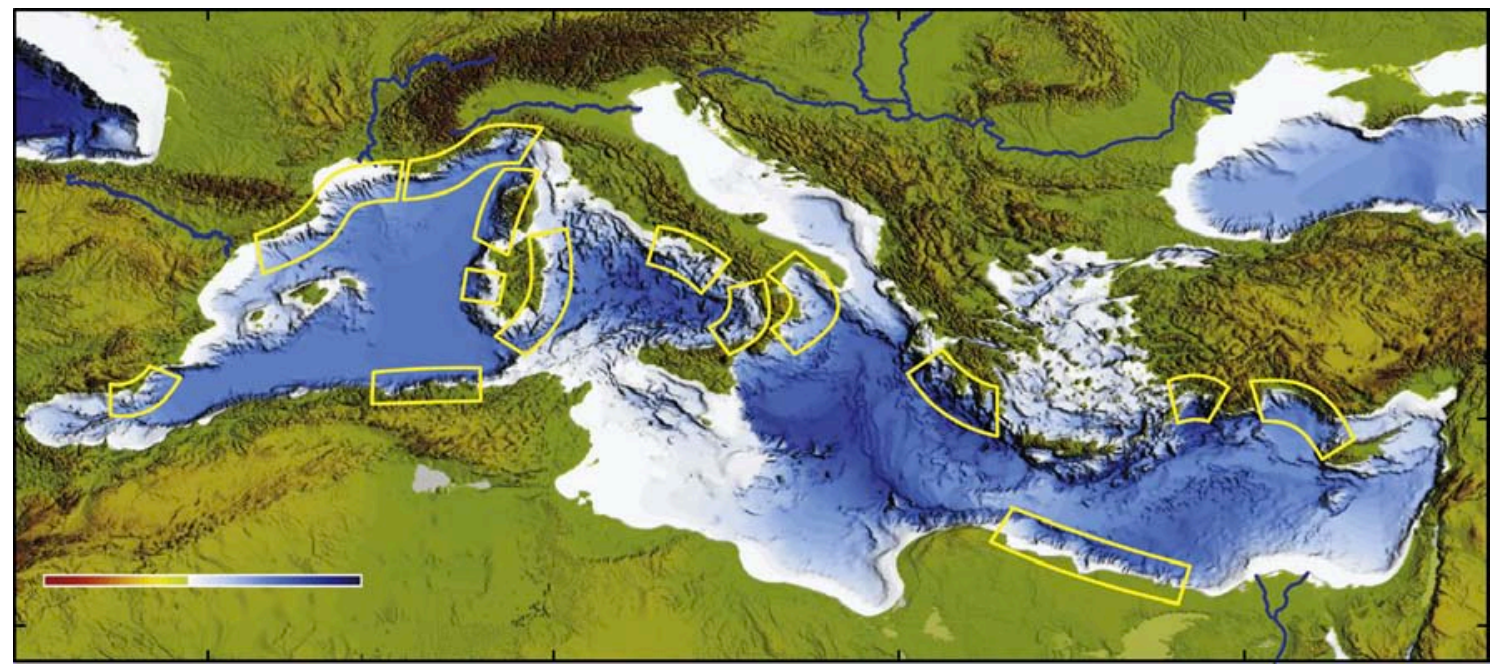


Fig. 2. Submarine drainage network of the NW Mediterranean Sea including the Western Gulf of Lion and the Catalan margin. Valencia Channel (VC) is a mid-ocean type submarine valley where some of the canyons draining the Catalan margin die. Also note the group of canyons to the north ending into Sete Canyon (SC). The main rivers opening at short distance from submarine canyon heads are also indicated. Canyon acronyms as in Table 1 and Figs. 3, 6 and 10. HC: Herault Canyon. AC: Aude Canyon. PC: Pruvot Canyon. LDC: Lacaze-Duthiers Canyon. CCC: Cap de Creus Canyon. LFC: La Fonera Canyon. BC: Blanes Canyon. ArC: Arenys Canyon. BeC: Besos Canyon. CPC: Can Pallisso Canyon. MC: Morras Canyon. BerC: Berenguera Canyon. FC: Foix Canyon. CC: Cubelles Canyon. TR: Ter River. ToR: Tordera River. LLR: Llobregat River.

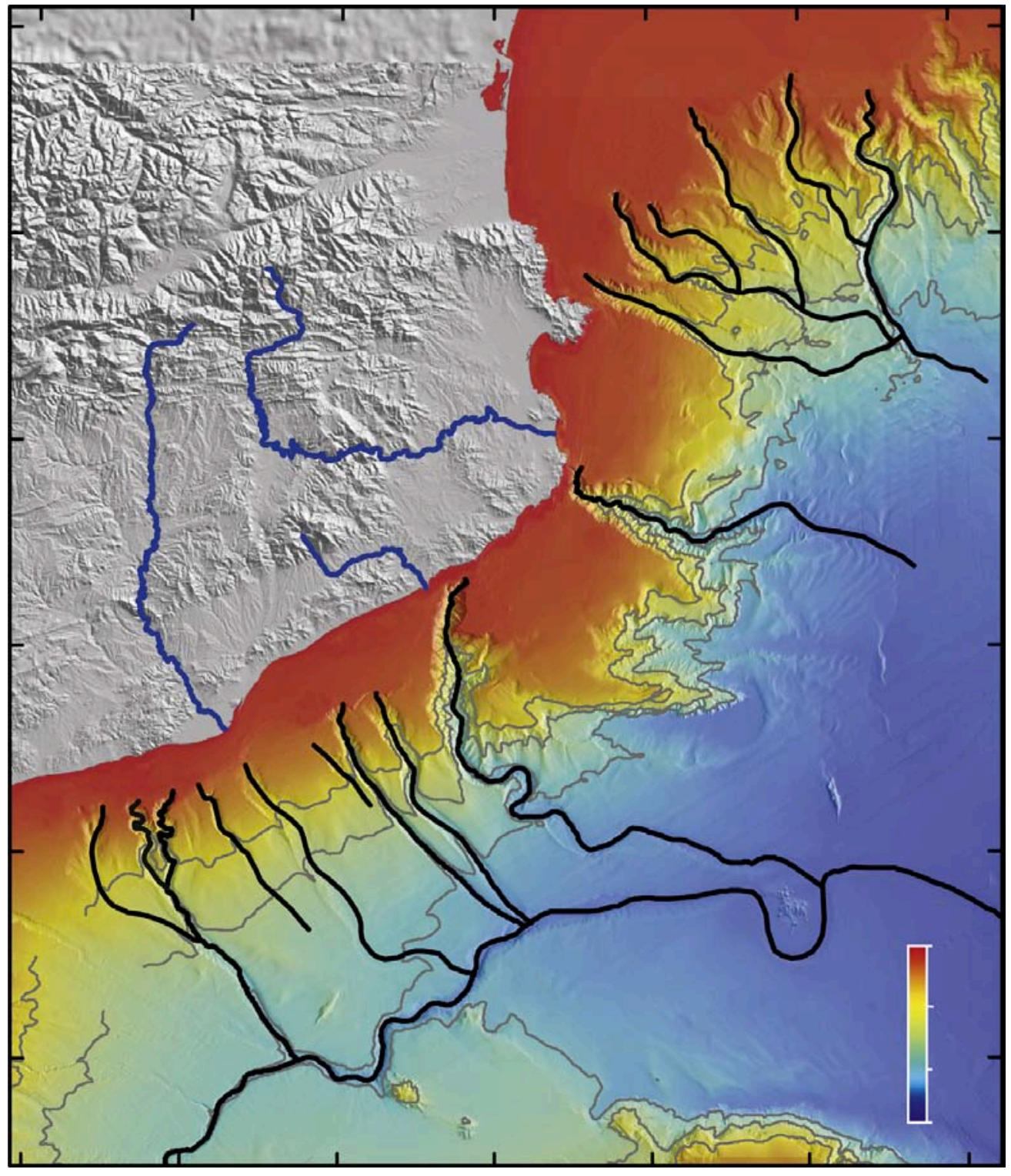


Fig. 3. Canyon incision length (IL) vs. distance to the nearest shoreline (DS) plot for submarine canyons in the study area. IL is the incision of the canyon into the continental shelf shoreward of the shelf edge projection normal to the canyon axis. DS is the shortest canyon rim distance to the nearest shoreline, which usually corresponds to the distance between the canyon tip and the shoreline. Note that some ambiguity could exist in the measurement of IL, in particular when the shelf edge is poorly defined or for specific canyon/shelf edge configurations, which is also dependent on the resolution of the bathymetry data. The plot clearly shows the canyons with the highest potential to capture coastal sediments and funnel them to the deep (i.e. those with the smaller DS and large IL, such us CCC, LFC and BC), canyons with some capturing potential (i.e. those with intermediate DS and variable IL, such as LDC and FC), and those with very weak or no capturing potential at all (i.e. those with intermediate to large DS and variable IL, such as SC, HC, AC or ArC and nearby canyons). DS in Foix Canyon (FC) corresponds to its eastern branch (see Table 1). Canyon acronyms as in Table 1 and Figs. 2, 6 and 10.

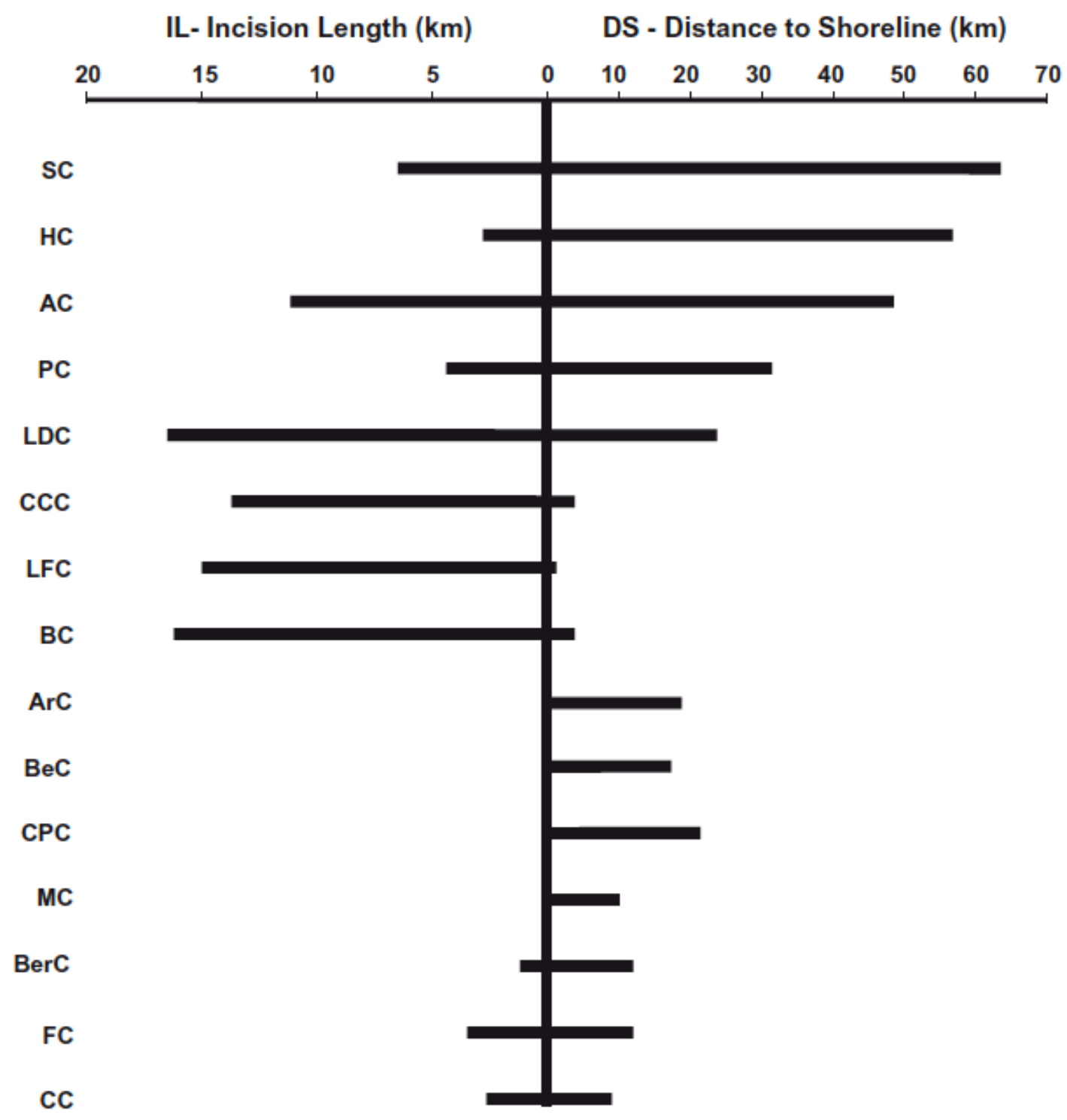


Fig. 4. Large-scale pressure and temperature fields over the NE Atlantic and Mediterranean regions. (A) Image illustrating the negative phase of the Eastern Atlantic Pattern (EAP) leading to severe heat losses and dense water formation over the continental shelf and offshore in the NW Mediterranean Sea mostly during winter months. Note the high pressure centre to the west of Ireland and the low pressure tongue from Northern Europe penetrating into the Western Mediterranean region, and the associated intrusion of cold air from the north, as indicated by the 7 C contour (in black). Also note the NNE-SSE to ENE-WSW cold air flux over the Iberian Peninsula and nearby marine areas. The image corresponds to the 27th of January 2005. (B) Image illustrating the atmospheric configuration that led to a severe coastal storm associated to eastern winds over the NW Mediterranean Basin. Note the high-pressure centre over the North Sea blocking the west zonal circulation and leading to the formation of a relative low over the Western and Central Mediterranean Sea. The 7 C contour (in black) is also indicated for ease of comparison to (A). The image corresponds to the 26th of December 2008. Data from the National Centers for Environmental Prediction-National Centre for Atmospheric Research (NCEP/NCAR) reanalysis. Isobars are in white while temperatures at sea level pressure are shown in colour according to the scale to the right. Isobar equidistance is 2 mbar. For interpretation of the references to colour in this figure legend, the reader is referred to the web version of this article. 

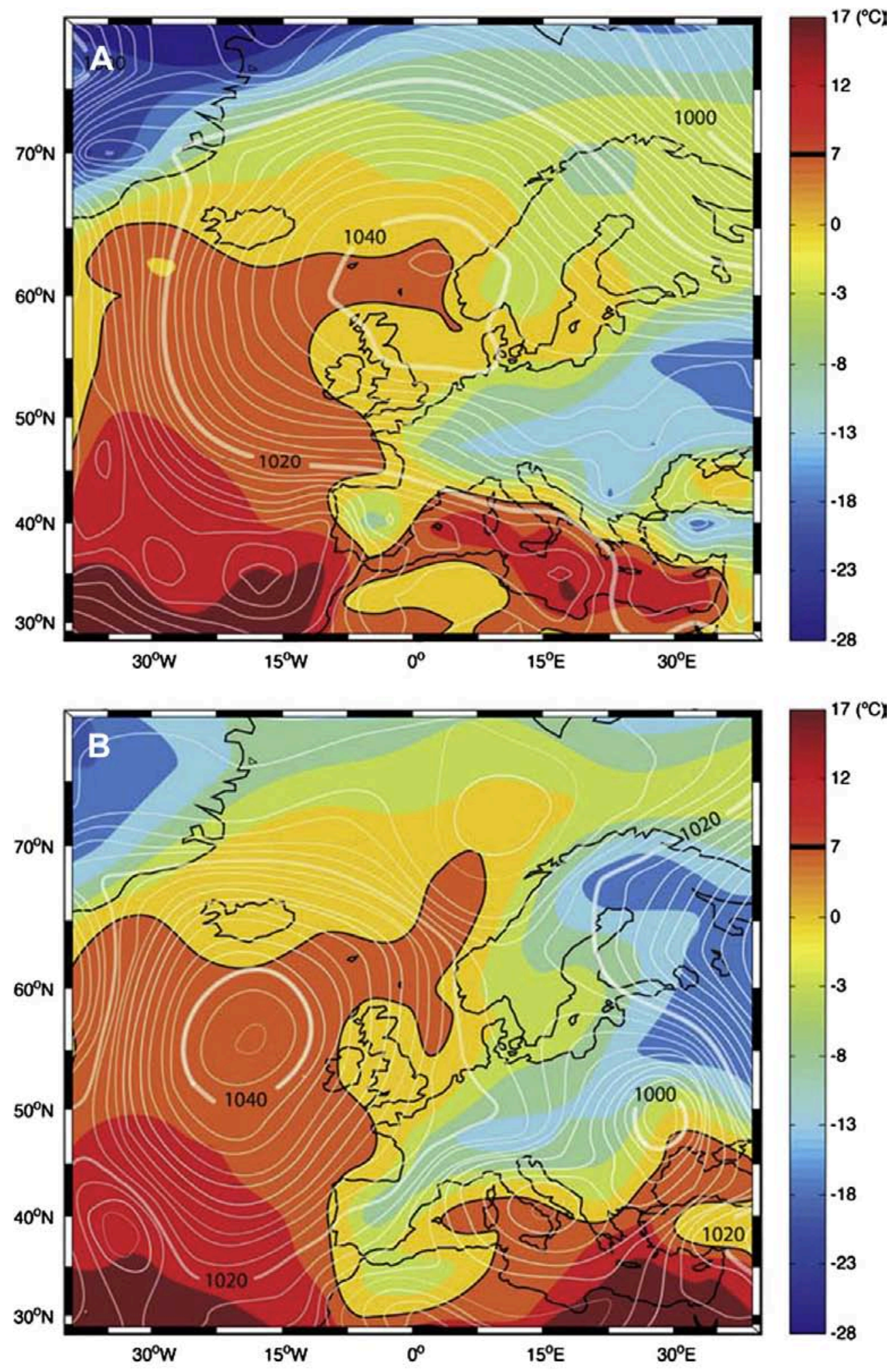
Fig. 5. Conceptual sketch of the three main oceanographic processes driving the NW Mediterranean Sea: dense shelf water cascading (DSWC), offshore convection and eastern storms (the "three tenors"). DSWC and offshore convection are driven by cold northern winds (oblique orange arrow) and occur in later winter and early spring. DSWC involves the near-bottom downslope flow of dense waters formed over the continental shelf. Dense shelf water formation also produces convection over the continental shelf. Offshore convection leads to the deepening of the mixed layer, eventually down to the basin floor. Both DSWC and offshore convection result in pronounced surface heat losses (upwards pointing red to orange winding arrows), evaporation and, subsequently, buoyancy loss. Eastern winds (oblique red arrow) bring humid winds against the coast where they trigger coastal storms. Eastern storms often occur in winter but also in other times of the year, especially in late summer and autumn when the sea surface is warmest and releases large amounts of moisture to the atmosphere. The "three tenors" induce vertical and horizontal mass and energy transfers from shallow layers to the deeper ones and vice versa, and from the coastal to the open ocean and vice versa. Water depths and bathymetric profile are only indicative and not to scale (modified from Pusceddu et al., 2010). For interpretation of the references to colour in this figure legend, the reader is referred to the web version of this article.

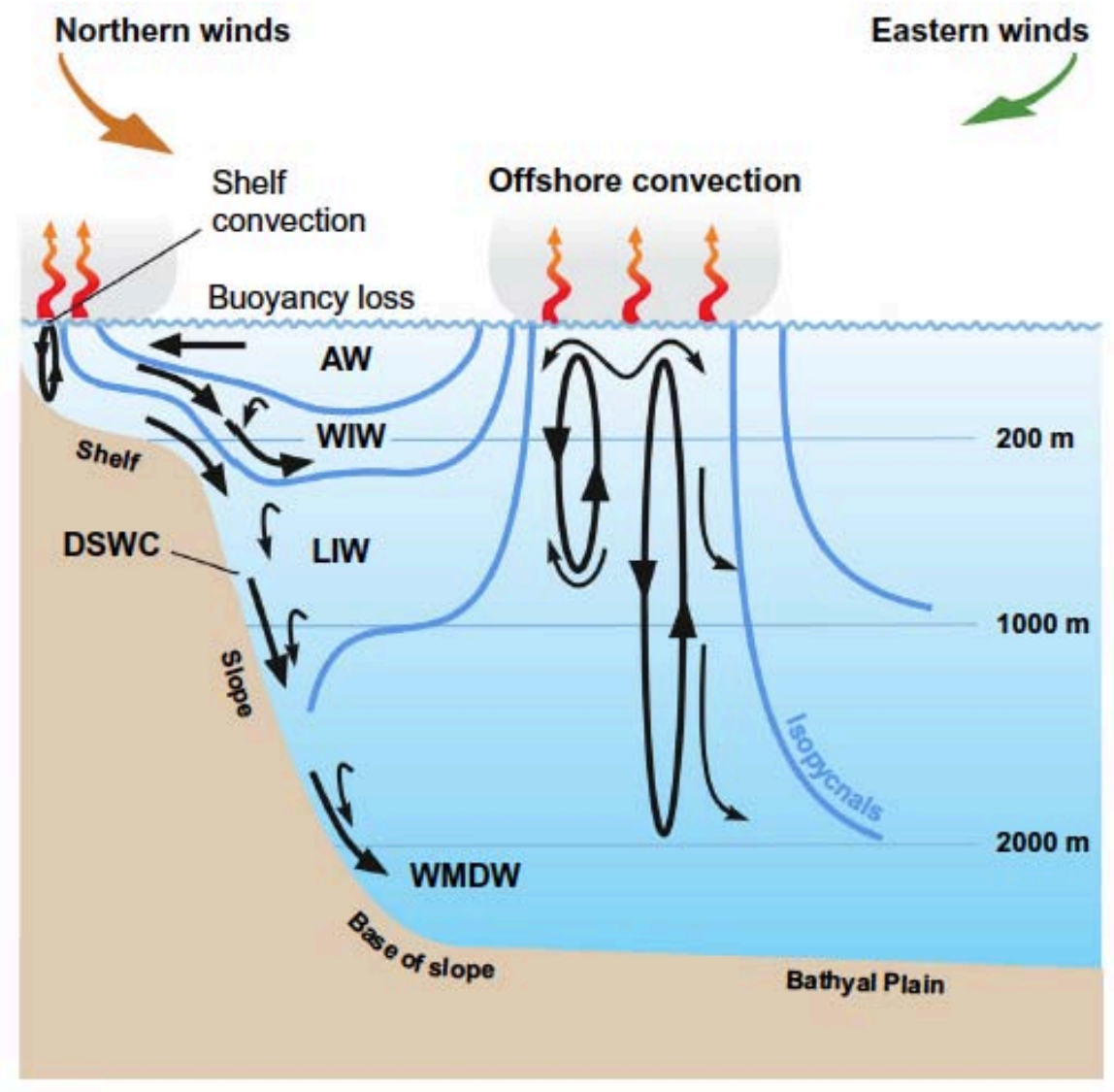


Fig. 6. (A) Dense shelf water cascading (DSWC) and offshore convection conditions jointly with associated atmospheric and oceanographic processes draped on a $3 \mathrm{D}$ view of the NW Mediterranean region. Tramuntana and mistral cold northern winds are the main forcings. The margin parallel anticlockwise mesoscale circulation imaged by the west and southwest pointing large whitish arrows corresponds to the Northern Current (NC; note that in this view it is shifted shoreward of its mean path because of the lack of space to accommodate all elements). Wide whitish arrows pointing downslope represent the export paths of dense shelf water, occurring mainly along submarine canyons. The light grey transparent oval indicates the area of offshore convection. The near-bottom spreading of shelf and offshore-formed dense waters over the deep basin is also illustrated (straight white arrows and white concentric lines). VC: Valencia Channel. (B) Dense shelf water volumes produced (blue) and exported (green) during the intense cascading episode of early 2005 superimposed on a 3D view of the NWMediterranean region. $1800 \mathrm{~km} 3$ of dense shelf water formed over the Gulf of Lion shelf, while 360 $\mathrm{km} 3$ formed on the North Catalan shelves, thus totalling $2160 \mathrm{~km} 3$. The total amount exported to the deep was $2270 \mathrm{~km} 3$, giving a difference of $110 \mathrm{~km} 3$ (violet) that is attributed to mixing processes increasing the density of the water masses surrounding the newly formed dense shelf water. In total, $1220 \mathrm{~km} 3$ cascaded downslope east and north of Cap de Creus, mostly through CCC and LDC (1010 and $170 \mathrm{~km} 3$, respectively), and $1050 \mathrm{~km} 3$ were exported across the North Catalan slope, mostly through BC and LFC (390 km3 each). Note that $460 \mathrm{~km} 3$ of dense shelf water escaped to the south by flowing attached to the coastline inland of CCC. Other $50 \mathrm{~km} 3$ escaped over the shelf to the south of BC. All figures are in km3. Volumes are from Ulses et al. (2008a). (C) Eastern storm conditions and associated processes on top of a $3 \mathrm{D}$ view of the NWMediterranean region. Humid winds from the east (large grey arrow) blow over the coast where they are forced to ascend when encountering the coastal ranges, thus releasing its water load and causing river flash floods (vertical blue arrows) that carry large amounts of sediment to the coast and shelf. Eastern winds push water and waves against the shoreline (white wavy patterns), where in addition of severe damage, they resuspend bottom sediment that abrades shallow water benthic communities, thus adding to the pool of matter able to being exported offshore, mainly along submarine canyons (wide whitish arrows along the main canyons) as evidenced by the 26th of December 2008 big eastern storm (Sanchez-Vidal et al., 2012). Tordera, Ter, Fluvia and Tet are the main local rivers. The Northern Current (NC) arrow shows the regular location of this mesoscale current flowing southwestward over the continental slope. Canyon acronyms in (A), (B) and (C) as in Table 1 and Figs. 2, 3 and 10. For interpretation of the references to colour in this figure legend, the reader is referred to the web version of this article. 

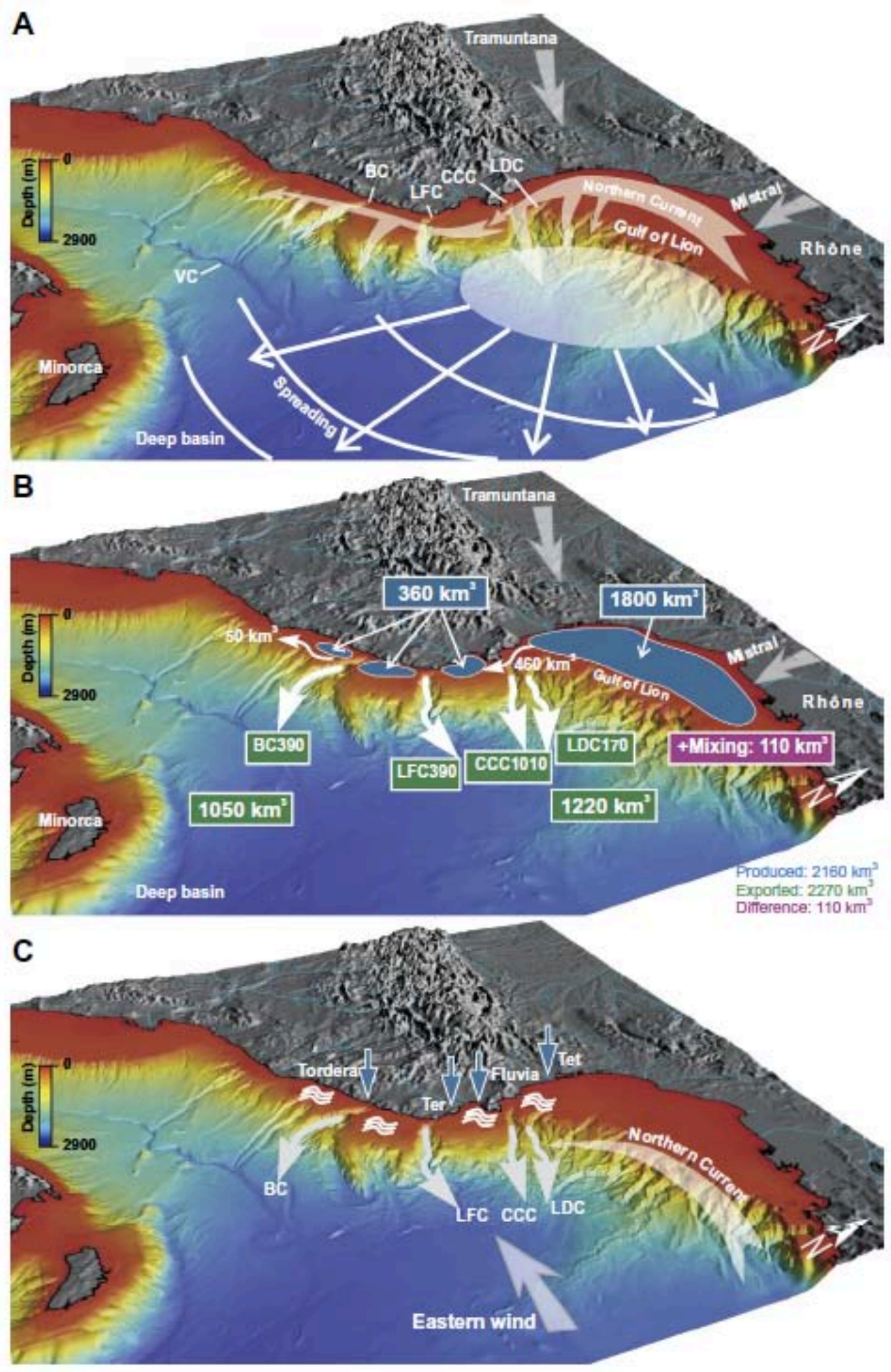
Fig. 7. Effect of Dense Shelf Water Cascading (DSWC) and storms on currents and deep-water particle fluxes as illustrated by the intense 2005-2006 DSWC event and a stormy period in late 2008 and early 2009. The Cap de Creus Canyon (CCC) area is severely impacted by seasonal DSWC events whilst the Blanes Canyon (BC) area is prone to strong impacts by eastern storms. (A) Temporal evolution of near bottom in situ temperature and current speed at $300 \mathrm{~m}$ of water depth, and near bottom total mass flux (TMF) caught by sediment traps deployed along the axis of the CCC from 300 to 1900 mof water depth from late 2005 to fall 2006. The abrupt temperature drop and increased current speed and the concomitant increased TMF along the canyon are all indicators of the occurrence of a DSWC event. The caps at the end of each box indicate the extreme values, the box is defined by the lower and upper quartiles, and the horizontal line in each box is the median (based on data in Pasqual et al., 2010, and Palanques et al., 2012). (B) Temporal evolution of significant wave height (Hs, as an indicator of stormy conditions) in the continental shelf near the BC head, near bottom current speed at $300 \mathrm{~m}$ of water depth, and TMF caught by near-bottom sediment traps deployed along the axis of the BC from 300 to $1500 \mathrm{~m}$ of water depth during late 2008 to fall 2009. The increased Hs during autumn-winter months and increased current speed result in the enhancement of the downcanyon transport of particles due to storms. Note that the effects on TMF last for a few months after the stormy period (based on data in Lopez-Fernandez et al., this volume-b).

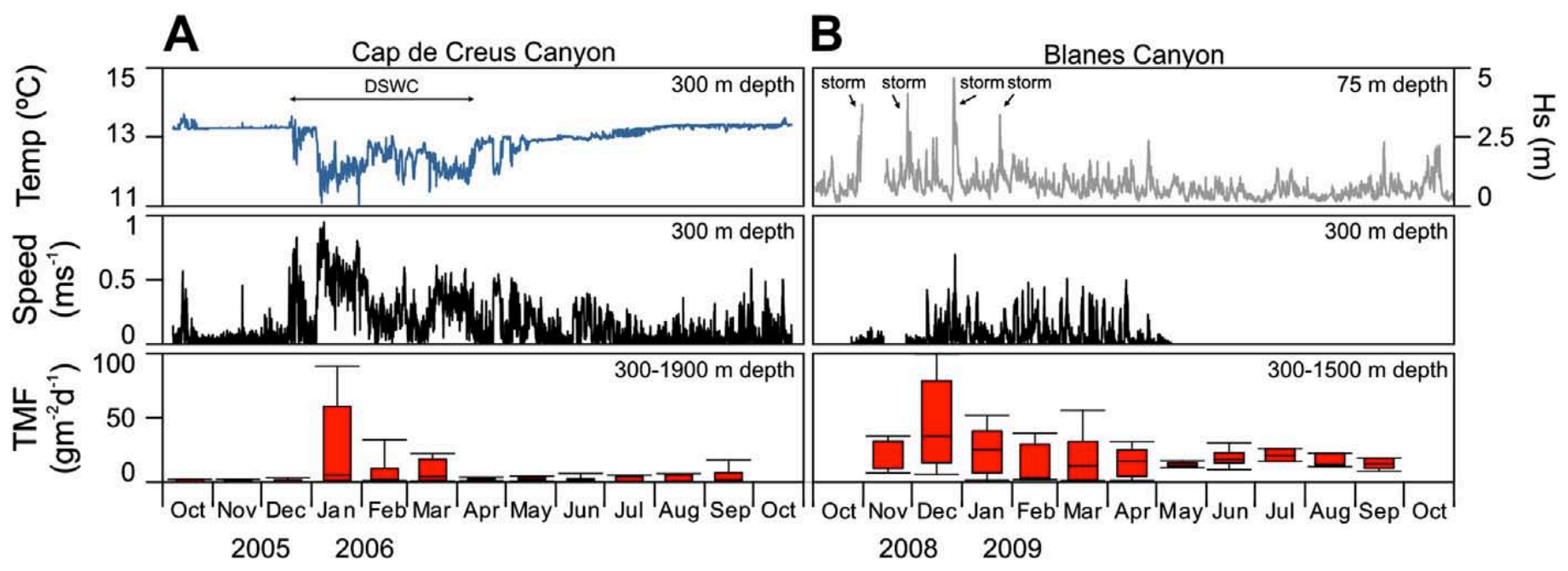


Fig. 8. Monthly chlorophyll-a concentration maps derived from the SeaWiFS sensor illustrative of a year-round cycle in the Western Mediterranean Sea. Note the late winter- early spring maximum (illustrated by the April 2005 image), when dense shelf water cascading (DSWC) and offshore convection occur, and the summer minimum (illustrated by the July 2005 image). Maps obtained through the Ocean Colour Portal of the Institute for Environment and Sustainability (Joint Research Centre of the European Commission, Ispra, Italy (http://oceancolour.jrc.ec.europa.eu/).
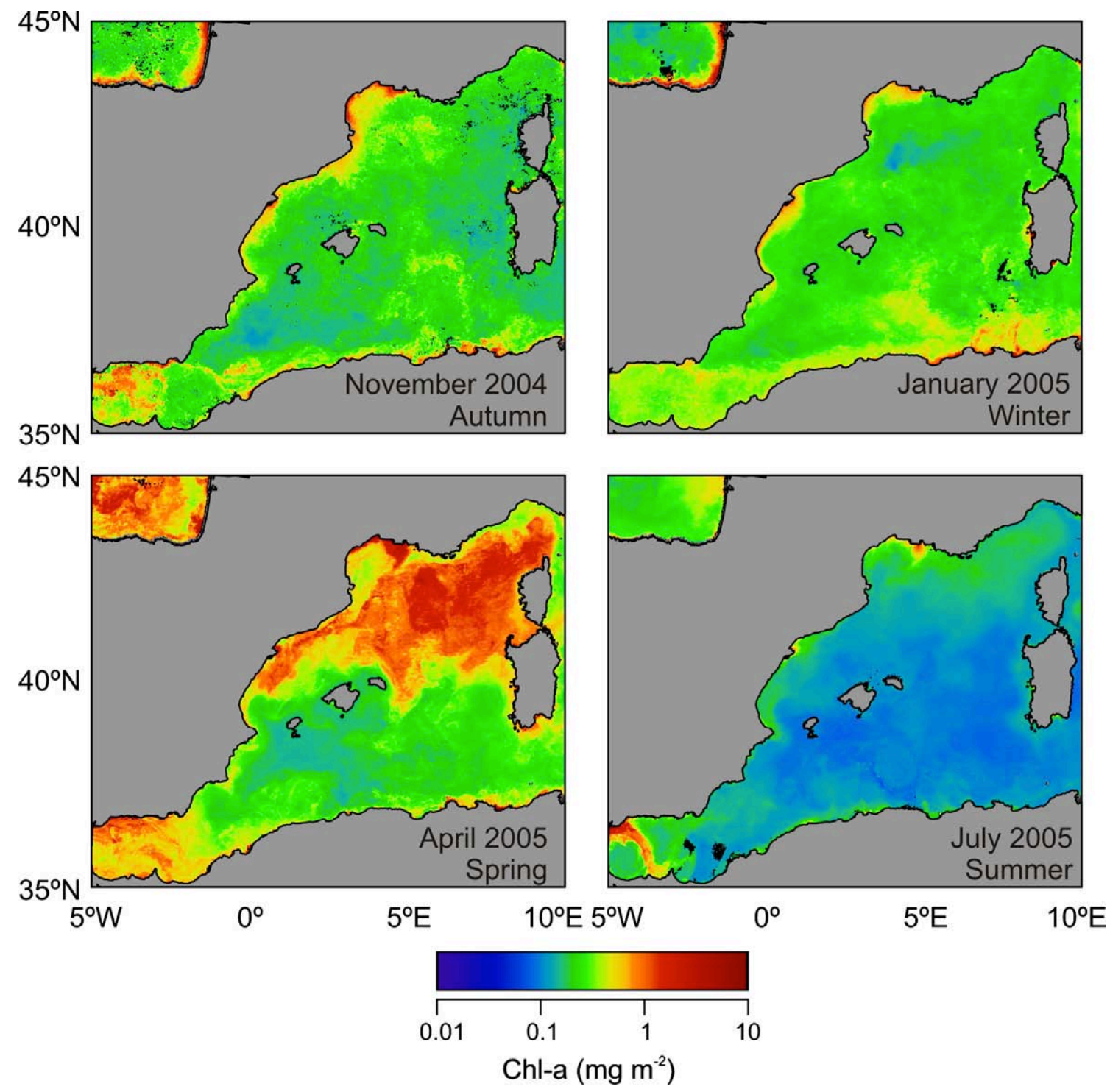
Fig. 9. Examples of infaunal organisms collected in the Blanes Canyon and its adjacent western open slope. (A-E) Nematoda. (F) Sipunculida. (G) Larvae of insecta. (H) Bivalvia. (I) Caudofaveata. (J) Ostracoda. (K) Copepoda Harpacticoida. (L-M) Isopoda. (O) Cumacea. (P) Anfipoda (photos: Nematoda and Copepoda Harpacticoida by S. Roman; Sipunculida, larvae of insecta, Bivalvia, Caudofaveata, Ostracoda, Isopoda, Cumacea and Anfipoda by C. Arca).
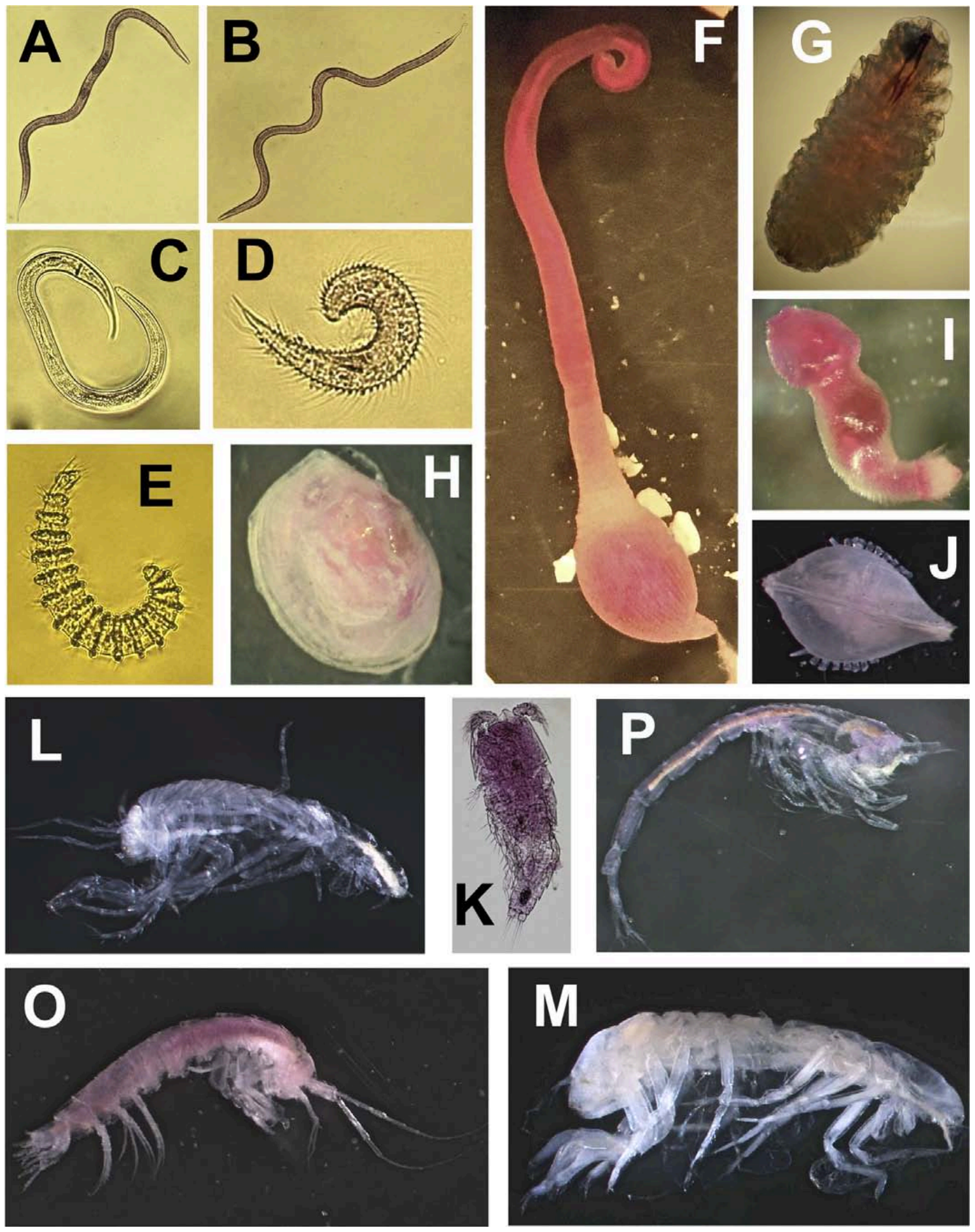
Fig. 10. Mid 2004 to spring 2007 time series of abiotic variables (potential temperature, current speed and salinity -four upper plots) and daily landings of the deep-sea red shrimp A. antennatus at Palamos port, face to La Fonera Canyon head (lower plot). The two upper plots correspond to Cap de Creus Canyon (CCC) at $500 \mathrm{~m}$ depth while the third and fourth plots from above correspond to the open lower continental slope (LCS) south of CCC at about $1000 \mathrm{~m}$ of water depth. The plots illustrate an intense dense shelf water cascading (DSWC) event in early 2005 and a slightly milder event in early 2006, which caused coeval temporary collapses of the A. antennatus fishery. Note that the DSWC signal coming from the north (where CCC is) arrives with some delay to the LCS, where its duration is also shorter and its intensity weaker. Note that the vertical scales in the potential temperature plots differ from one each other (modified from Company et al., 2012).

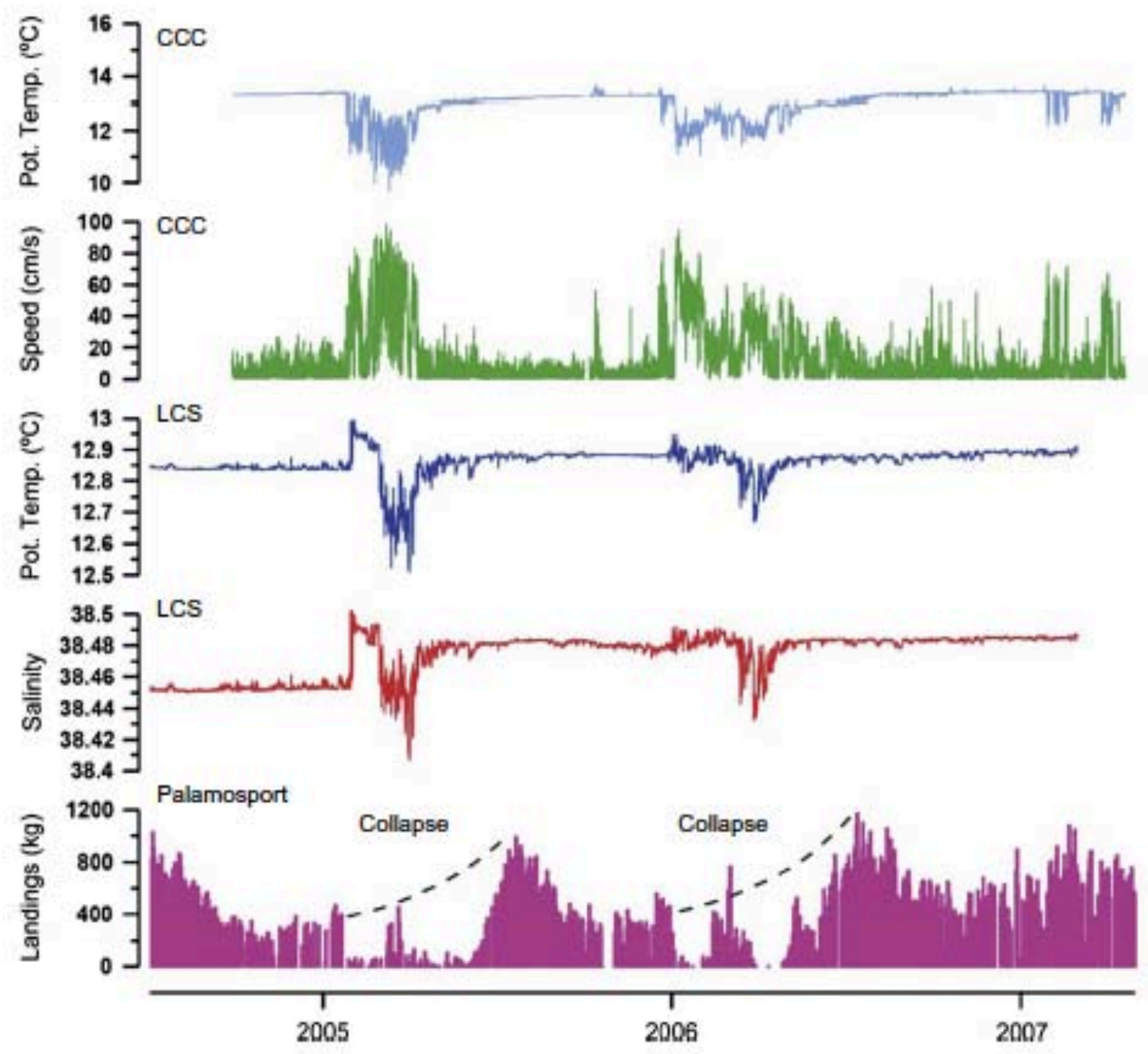


Fig. 11. Examples of marine litter from the Mediterranean deep seafloor. (A) Marine litter and (B) megafauna catch from a trawl at $1350 \mathrm{~m}$ depth in the Blanes slope. (C) Glass bottles collected at $1750 \mathrm{~m}$ depth in the Blanes slope. (D) Vessel engine filters collected at $1500 \mathrm{~m}$ depth in the Blanes slope. (E) Plastics collected at $2000 \mathrm{~m}$ depth in the Blanes slope. (F) Lost or discarded longline collected at $1200 \mathrm{~m}$ in the Ionian Sea (photos by E. Ramirez-Llodra and A. Mecho).
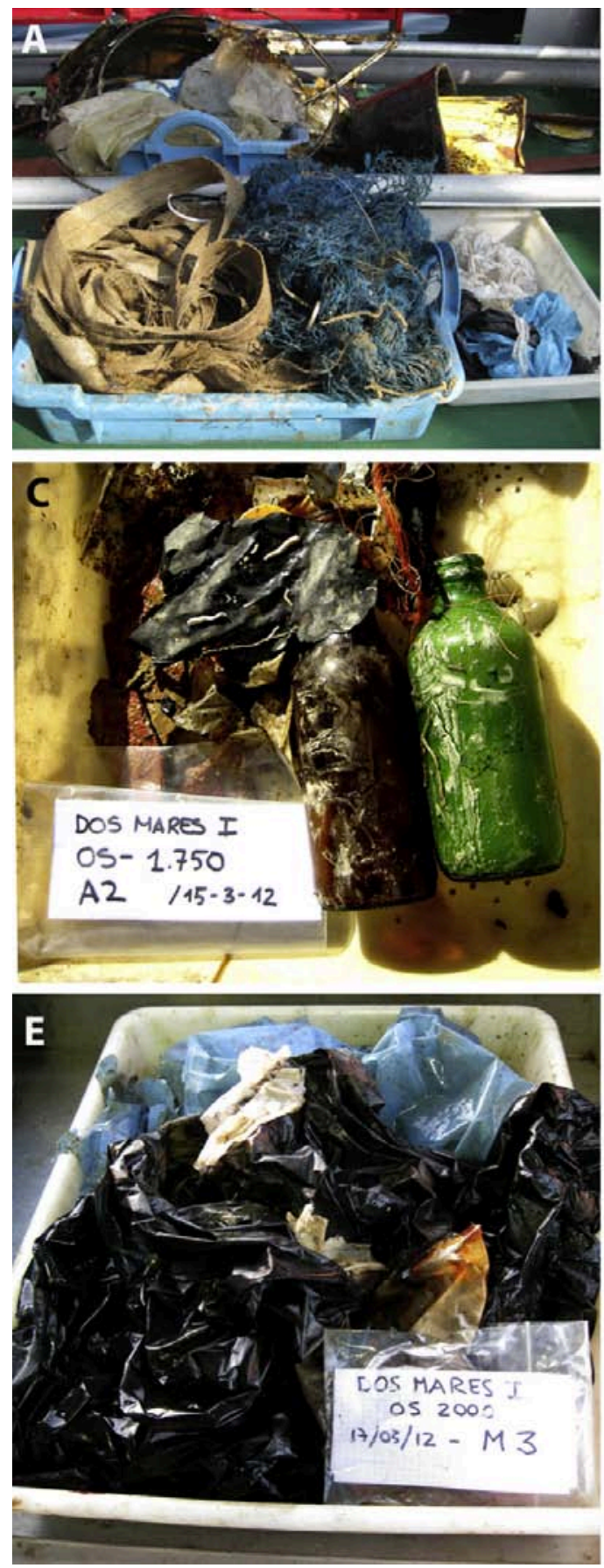
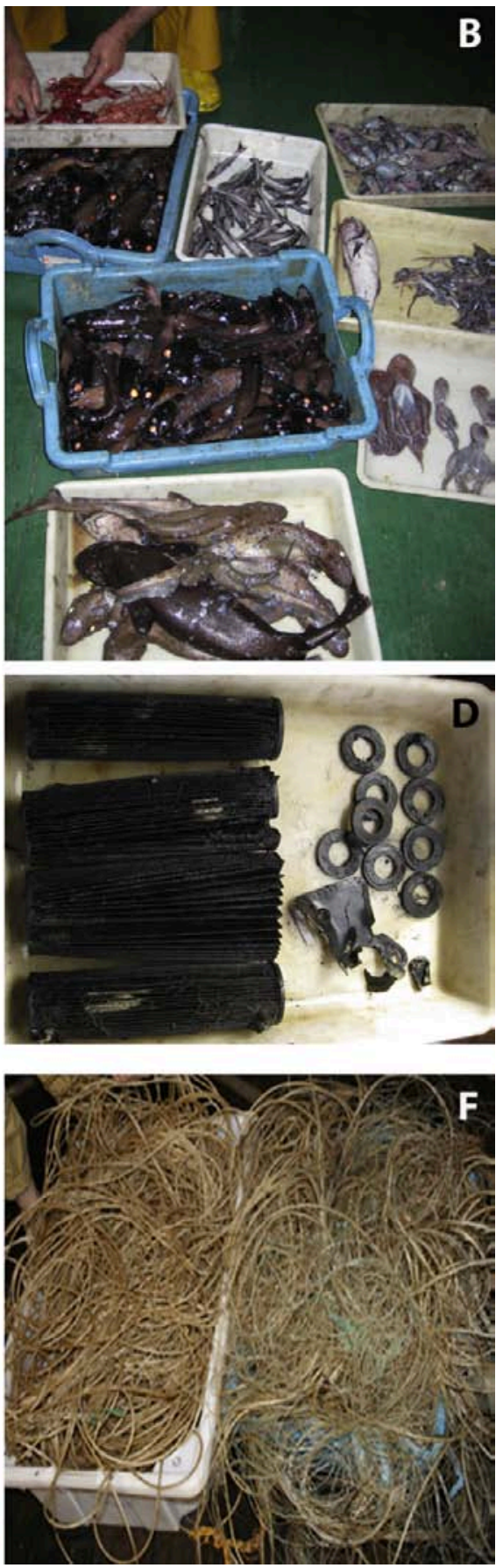
Fig. 12. Total mercury ( $\mathrm{THg}$ ) levels $(\mathrm{lg} / \mathrm{g}$ wet weight) in twelve deep-sea fishes and the red shrimp Aristeus antennatus caught at depths ranging from 900 to $2800 \mathrm{~m}$ depth in the NW Mediterranean (based on data in Koenig et al., 2013c).

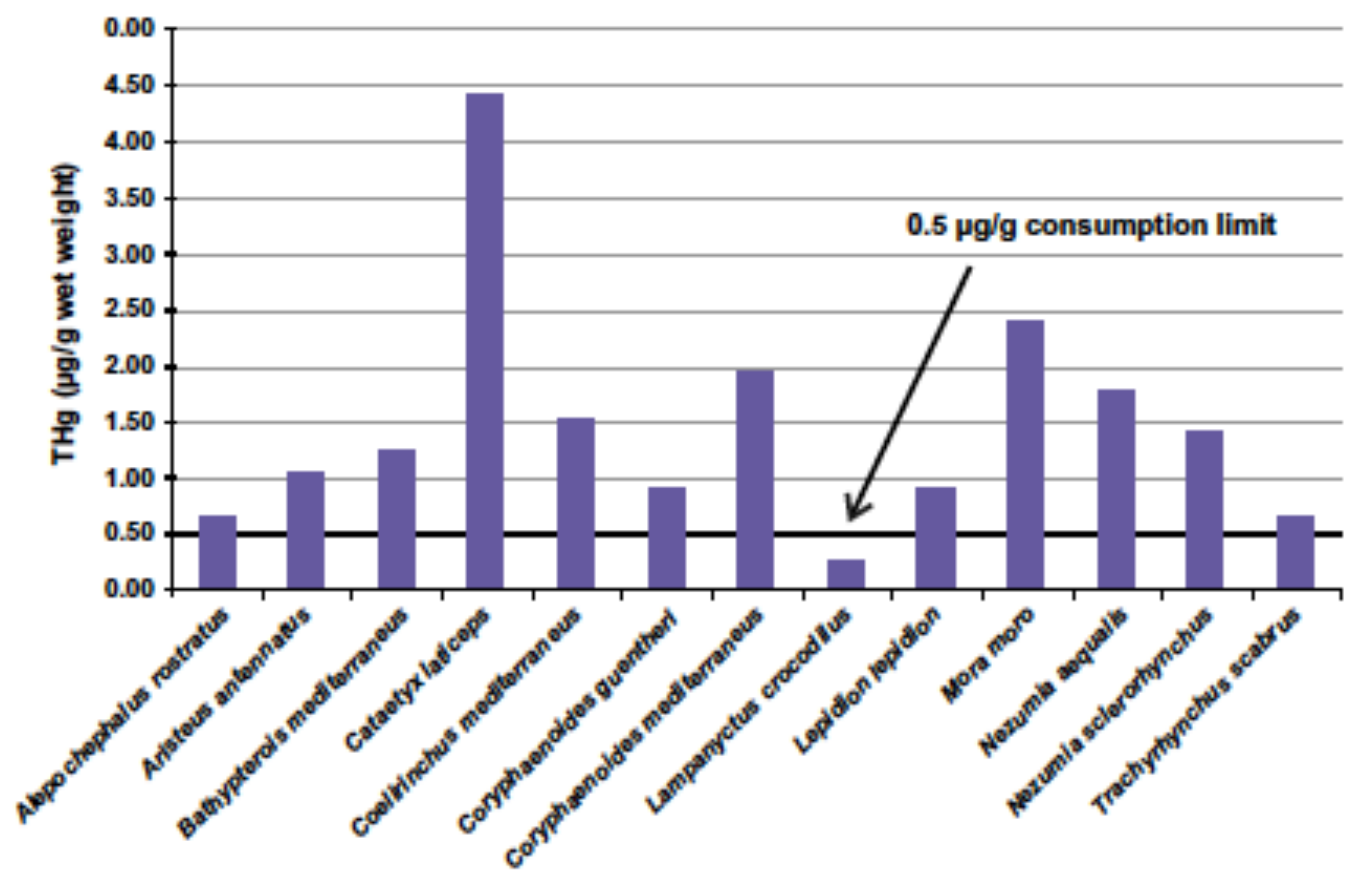


Table 1 Main geomorphic characteristics of the submarine canyons in the Catalan margin and Western Gulf of Lion. The North and South Catalan margins subdivision is defined according to Amblas et al. (2006). IL: Canyon incision length shoreward of the shelf edge projection. DS: Shortest canyon rim distance to the shoreline, which usually corresponds to the distance between the canyon tip and the shoreline. D1500: Distance to the coast where $1500 \mathrm{~m}$ of axial depth are reached. When the axial incision is poorly defined or discontinuous the assertion (Yes) is in between brackets. Extreme values (one or two) for each parameter are in bold. Canyon acronyms as in Figs. 2, 3, 6 and 10. Note that the precision of the calculated values relies upon the bathymetry resolution, which changes across the study area. Numbers have been rounded wherever required. NP: Not pertinent. 1: Higher values correspond to higher sinuosity. 2: Values corresponding to the central and eastern canyon branches, respectively. 3: Calculated for the eastern branch.

\begin{tabular}{|c|c|c|c|c|c|c|c|c|c|c|c|c|}
\hline & Ganyon & IL $(\mathrm{km})$ & DS $(\mathrm{km})$ & $\begin{array}{l}\text { Total } \\
\text { length } \\
(\mathrm{km})\end{array}$ & $\begin{array}{l}\text { Depth } \\
\text { range } \\
(\mathrm{m})\end{array}$ & $\begin{array}{l}\text { Total along axis } \\
\text { depth difference } \\
\text { (m) }\end{array}$ & $\begin{array}{l}\text { Maximum flank drop } \\
\text { height }(m) \text { and } \\
\text { corresponding axial } \\
\text { depth }(m)\end{array}$ & $\begin{array}{l}\text { D1500 } \\
(\mathrm{km})\end{array}$ & $\begin{array}{l}\text { Width }(\mathrm{km}) \text { amongst } \\
\text { canyon edges at } \\
1000,1500 \text { and } \\
2000 \mathrm{~m} \text { axial depth }\end{array}$ & $\begin{array}{l}\text { Canyon floor width } \\
(\mathrm{km}) \text { at } 1000,1500 \\
\text { and } 2000 \mathrm{~m} \text { axial depth }\end{array}$ & $\begin{array}{l}\text { Axial } \\
\text { incision }\end{array}$ & $\begin{array}{l}\text { Sinuosity } \\
\text { index }^{1}\end{array}$ \\
\hline \multirow{5}{*}{$\begin{array}{l}\text { Western Gulf } \\
\text { of Lion }\end{array}$} & Sete (SC) & 6.5 & 63 & 106 & $150 \rightarrow 2400$ & 2250 & $510(660)$ & 81 & $6.5 / 11.5 / 4.6$ & $2.2 / 2.1 / 2.2$ & No & 1.25 \\
\hline & Herault (HC) & 2.9 & 57 & 59 & $100-1920$ & 1820 & $470(620)$ & 73 & $7.6 / 4.6 / \mathrm{NP}$ & $3.3 / 1.6 / \mathrm{NP}$ & Yes & 1.15 \\
\hline & Aude (AC) & 11.2 & 49 & 67 & $75-1700$ & 1625 & $540(1020)$ & 56.2 & $14.4 / 5.1 / \mathrm{NP}$ & $3.2 / 1.7 / \mathrm{NP}$ & Yes & 1.09 \\
\hline & Pruvot (OC) & 4.3 & 31 & 40 & $120-1440$ & 1320 & $390(540)$ & NP & $2.5 / \mathrm{NP} / \mathrm{NP}$ & $1.4 / \mathrm{NP} / \mathrm{NP}$ & (Yes) & 1.18 \\
\hline & Lacaze-Duthiers (LDC) & 16.5 & 23 & 92 & $120-2080$ & 1960 & $730(880)$ & 43.2 & $8.7 / 5.9 / 2.8$ & $2,1 / 1.5 / 1.4$ & Yes & 1.17 \\
\hline \multirow{3}{*}{$\begin{array}{l}\text { North Catalan } \\
\text { margin }\end{array}$} & Cap de Creus (CCC) & 13.8 & 4 & 96 & $125-2140$ & 2015 & $780(1230)$ & 45.6 & $8 / 9 / 8.5$ & $1.3 / 2.2 / 0.2$ & Yes & 1.11 \\
\hline & La Fonera (LFC) & 15 & 0.8 & 110 & $60-2550$ & 2490 & $1620(1980)$ & 172 & $7.1 / 13.3 / 16.3$ & $0.5 / 0.4 / 1.2$ & No & 1.21 \\
\hline & Blanes (BC) & 16.2 & 4 & 184 & $70-2600$ & 2530 & $1250(1650)$ & 23.0 & $6 / 12,1 / 11$ & $0.7 / 1 / 1.2$ & (Yes) & 1.47 \\
\hline \multirow{7}{*}{$\begin{array}{l}\text { Southem Gatalan } \\
\text { margin }\end{array}$} & Arenys (AC) & $\mathbf{0}$ & 19 & 76 & $150-2380$ & 2230 & $570(1100)$ & 42.0 & $7.7 / 5.6 / 5.2$ & $3.8 / 3.1 / 2.7$ & No & 1.06 \\
\hline & Besos $(\mathrm{BeC})$ & $\mathbf{0}$ & 18 & 79 & $100-2380$ & 2280 & $660(1190)$ & 17.9 & $5 / 3.8 / 3.8$ & $0.2 / 0.7 / 0.3$ & No & 1.03 \\
\hline & Gan Pallisso (CPC) & $\mathbf{0}$ & 21 & 25 & $350-1400$ & 1050 & $240(900)$ & NP & $3.5 / \mathrm{NP} / \mathrm{NP}$ & $0.7 / \mathrm{NP} / \mathrm{NP}$ & No & 1.01 \\
\hline & Morras (MC) & $\mathbf{0}$ & 10 & 93 & $130-2150$ & 2020 & $400(1140)$ & 40.4 & $8.9 / 12.5 / 10.1$ & $4.8 / 73 / 5.6$ & No & 1.12 \\
\hline & Berenguera (BerC) & 1.2 & 12 & 52 & $110-1650$ & 1540 & $330(920)$ & 44.3 & $3.5 / 2.6 / \mathrm{NP}$ & $1.5 / 0.9 / \mathrm{NP}$ & Yes & 1.06 \\
\hline & Foix (FC) & 3.5 & $10.5-12^{2}$ & 97 & $70-2180$ & 2110 & $640(1090) / 580(1500)^{2}$ & $33.2^{3}$ & $4.3-3.6^{2} / 3.8 / 4.6$ & $1-0.4 / 0.5 / 2.1$ & Yes & $1.23^{3}$ \\
\hline & Cubelles (CC) & 2.7 & 9 & 52 & $95-1760$ & 1665 & $370(680)$ & 48.8 & $4.8 / 3.3 / \mathrm{NP}$ & $2.1 / 0.8 / \mathrm{NP}$ & No & 1.18 \\
\hline
\end{tabular}

